\title{
Mouse models of human disease. Part II: Recent progress and future directions
}

\author{
Mary A. Bedell, ${ }^{1}$ David A. Largaespada, ${ }^{2}$ Nancy A. Jenkins, and Neal G. Copeland ${ }^{3}$ \\ Mammalian Genetics Laboratory, ABL-Basic Research Program, NCI-Frederick Cancer Research and Development Center, \\ Frederick, Maryland 21702-1201 USA
}

The development of new methods for manipulating the mouse genome, including transgenic and embryonic stem (ES) cell knockout technology, combined with greatly improved genetic and physical maps for mouse has revolutionized our ability to generate new mouse models of human disease. In Part I of this review (Bedell et al., this issue), we described in detail the various techniques and genetic resources that have facilitated mouse model development. In Part II of this review we highlight some of the recent progress that has been made in mouse model development and discuss areas where these mouse models are likely to contribute in the future. We have focused in part II only on those models where the homologous gene is mutated in both the human and mouse disease. A total of $\sim 100$ such genes are listed in seven tables according to the primary tissue or organ system they affect. The chromosomal location of each mapped disease gene in the mouse can be found in Figure 1. Detailed information about each mouse model can be obtained by entering the corresponding gene symbol into the Mouse Genome Database (MGD), maintained by the Jackson Laboratory at http://www.informatics.jax.org/ mgd.html. Detailed information about each human disease can be obtained using the Mendelian Inheritance in Man (MIM) accession nos. that are provided (McKusick et al. 1994). Each MIM entry may be accessed over the Internet at http://www3.ncbi.mlm.nih.gov/omim/, a site maintained by the National Center for Biotechnology Information. MIM accession nos. from 100050 195002 are for dominant traits; 200100-280000 are for recessive traits; and 300010-315000 are for X-linked traits.

Although we have tried to be as inclusive as possible, our list of mouse models is unlikely to be complete. In addition, space limitations have precluded a complete description of all mouse models we have listed; instead, we discuss only a few models in each section where significant progress in either identifying or utilizing a mouse model has been made recently. Much of the success in developing mouse models has been with monogenic traits; however, great potential lies in modeling polygenic diseases. In the last section, we review some of

Present address: ${ }^{1}$ Department of Genetics, University of Georgia, Athens, Georgia 30602 USA; $^{2}$ Department of Laboratory Medicine and Pathology, University of Minnesota Cancer Center, Minneapolis, Minnesota 55455 USA.

${ }^{3}$ Corresponding author.

E-MAIL copeland@ncifcrf.gov; FAX (301) 846-6666.

Hyperlinked version at http://www.cshl.org; follow links to journal. the recent progress in this area. Throughout the text and tables, we have cited only the most recent papers and refer to reviews whenever possible. Interested readers are encouraged to read the primary papers on each model and associated disease.

\section{Disorders of neural crest derivatives}

Cells from the neural crest differentiate into many different cell types including melanocytes of the skin and inner ear, neuronal and glial components of the peripheral nervous system, neuroendocrine cells of the adrenal medulla and thyroid, and cartilaginous and membranous bones of the skull. Mutations that affect melanocyte de velopment and cause visible effects on pigmentation have been arguably one of the most important phenotypic classes of mutations used in classical mouse genetics. The study of these mutants has revealed many aspects of melanocyte development, including the identification of factors controlling their survival and migration during embryogenesis, as well as pathways for pigment biosynthesis and transport. In Table 1, we have listed 11 genes in which mutations have been identified in mouse and human homologs that cause deficiencies in cells derived from the neural crest. All of these models share at least some aspect of the mutant phenotype with the corresponding human disease.

Excellent reviews of mouse and human pigmentation mutants have been published recently (Jackson 1994; Spritz 1994a, b; Barsh 1996). Here we will limit our discussion to three disorders of the neural crest: Hirshsprung's disease (HSCR; MIM 142623), Waardenburg syndrome (WS; MIM 193500, 193510), and piebald trait (PT; MIM 172800), for which cloning of each of the human disease genes was aided by the identification of mutations in the homologous mouse gene. All three syndromes display dominant inheritance, although some forms of HSCR and WS are recessive. HSCR patients have deficiencies in enteric ganglia resulting in megacolon, intestinal blockage, and chronic constipation. WS and PT patients have deficiencies in melanocytes of the skin and inner ear leading to pigment defects in the hair and hypopigmentation on the forehead, chest, and abdomen in PT patients, and pigment defects in the hair and eye and sensorineural deafness in WS patients.

\section{Hirshsprung's disease}

Mutations in the RET proto-oncogene cause dominant 


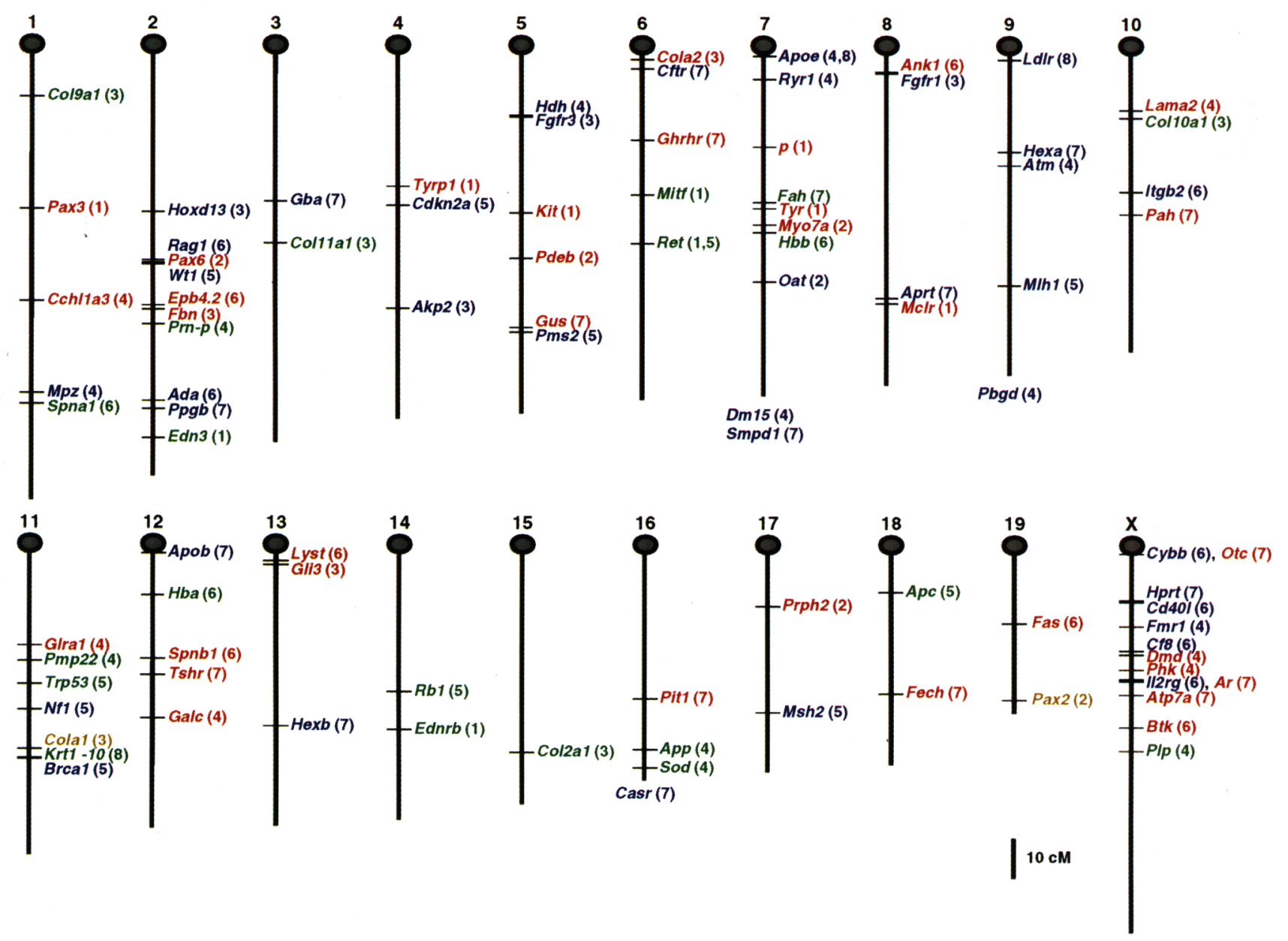

Figure 1. Chromosomal locations of mouse genes that are associated with monogenic traits in both humans and mice. The map positions are all from MGD and the tables that describe each gene are in parentheses. Genes in red are "classical" mutants, that is, arose spontaneously or were induced by chemical or radiation mutagenesis; genes in blue were created by knockout techniques; genes in green were altered by more than one technique such as a classical and a knockout allele have been generated, or a knockout allele and a transgenic model; genes in brown were mutated by transgene integration. Genes that have been expressed only as transgenes, but where the endogenous gene has not been altered, are not included. For simplicity, two keratin genes (Krt1-14 and Krt1-16) and Rag2, that are very closely linked to Krt1-10 and Rag1, respectively, have not been included on the map. Mouse genes that have not been mapped, but whose chromosome has been predicted on the basis of chromosomal synteny with mapped human homologs, are shown at the bottom of the chromosome. To our knowledge, the following genes have not been mapped in the mouse: Col5a2, G6pt, and UOX.

forms of HSCR, whereas mutations in endothelin $B$ receptor (EDNRB) and its cognate ligand, endothelin 3 (EDN3), cause recessive forms of HSCR (van Heyningen 1994; Chakravarti 1996; Edery et al. 1996; Hofstra et al. 1996). Curiously, patients with Shah-Waardenburg syndrome (a disease phenotypically similar to combined HSCR and WS) have mutations in EDNRB or EDN3, but not RET. HSCR is thus a prime example of a complex disease in which mutations in several different genes can produce the same disease and mutations in one gene can produce many different, albeit related, phenotypes.

A direct role for Ret in development of the enteric nervous system was demonstrated by use of knockout mice (Schuchardt et al. 1994). In mice homozygous for Ret null mutations, the intestines lack ganglia, have de- fective peristalsis, and are distended. This phenotype is similar to that caused by RET mutations in HSCR patients and provides a useful model for understanding the pathogenesis of this disease. There are some differences, however, between mice carrying Ret null mutations and HSCR patients. Ret mutations are completely recessive in mice but cause haploinsufficiency in humans. In addition, homozygous Ret null mice display renal agenesis, a phenotype not observed in HSCR patients. These phenotypic differences suggest that some tissues of mice and humans may respond differently to alterations in Ret signaling or to levels of Ret protein.

Knockout mutations in the mouse Ednrb and Edn3 genes were shown recently to be allelic with the spontaneous mutations piebald $|s|$ and lethal spotting $(1 s)$, 
Table 1. Disorders of neural crest derivatives

\begin{tabular}{|c|c|c|c|c|c|}
\hline $\begin{array}{l}\text { Mouse } \\
\text { gene } \\
\text { symbol }\end{array}$ & Gene name & $\begin{array}{l}\text { Mouse } \\
\text { model }^{a}\end{array}$ & Human disease & $\begin{array}{l}\text { Mendelian } \\
\text { inheritance } \\
\text { in Man } \\
\text { (MIM) no. }\end{array}$ & Selected references ${ }^{b}$ \\
\hline$E d n 3^{1 s}$ & Endothelin 3 & $\mathrm{~K}, \mathrm{~S}$ & $\begin{array}{l}\text { Waardenburg-Shah } \\
\text { syndrome }\end{array}$ & 277580 & $\begin{array}{l}\text { Baynash et al. (1994); Edery et } \\
\text { al. (1996); Hofstra et al. } \\
\text { (1996) }\end{array}$ \\
\hline$E d n r b^{s}$ & $\begin{array}{l}\text { Endothelin receptor } \\
\text { type B }\end{array}$ & $\mathrm{C}, \mathrm{K}, \mathrm{R}, \mathrm{S}$ & $\begin{array}{l}\text { Hirschprung's disease; } \\
\text { Waardenburg-Shah } \\
\text { syndrome }\end{array}$ & $\begin{array}{l}142623 \\
277580\end{array}$ & $\begin{array}{l}\text { Hosoda et al. (1994); } \\
\text { Puffenberger et al. (1994) } \\
{ }^{\star} \text { Chakravarti (1996) }\end{array}$ \\
\hline $\mathrm{Kit}^{W}$ & Kit oncogene & $\mathrm{C}, \mathrm{R}, \mathrm{S}$ & Piebald trait & 172800 & $\begin{array}{l}\text { *Besmer et al. (1993); } \\
\quad \text { ^Fleischman (1993); *Spritz } \\
\text { (1994a) }\end{array}$ \\
\hline$M c 1 r^{e}$ & Melanocortin 1 receptor & $S$ & Red hair color & 266300 & ${ }^{\star}$ Barsh $(1996)$ \\
\hline Mitf ${ }^{m i}$ & $\begin{array}{l}\text { Micropthalmia-associated } \\
\text { transcription factor }\end{array}$ & $\mathrm{C}, \mathrm{R}, \mathrm{TI}, \mathrm{S}$ & $\begin{array}{l}\text { Waardenburg syndrome } \\
\text { type } 2\end{array}$ & 193510 & $\begin{array}{l}{ }^{\star} J a c k s o n \text { and Raymond }(1994)_{;} \\
{ }^{\star} \text { Moore }(1995) \text {; Tassabehji et } \\
\text { al. (1995) }\end{array}$ \\
\hline Msx2 & Homeo box, msh-like 2 & $\mathrm{TE}$ & Craniosynostosis type 2 & 123101 & $\begin{array}{l}\text { Jabs et al. (1993); Liu et al. } \\
\qquad(1995 b)\end{array}$ \\
\hline 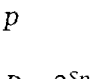 & Pink-eyed dilution & $\mathrm{C}, \mathrm{R}, \mathrm{S}$ & $\begin{array}{l}\text { Oculocutaneous } \\
\text { albinism, type II }\end{array}$ & 203200 & $\begin{array}{l}{ }^{\star} J a c k s o n(1994) ;{ }^{\star} \text { Spritz } \\
\text { (1994b); }{ }^{\star B a r s h}(1996)\end{array}$ \\
\hline $\mathrm{Pax}^{\mathrm{Sp}}$ & Paired box protein -3 & $\mathrm{R}, \mathrm{S}$ & $\begin{array}{l}\text { Waardenburg syndrome } \\
\text { type } 1 \\
\text { Klein-Waardenburg } \\
\text { syndrome }\end{array}$ & $\begin{array}{l}193500 \\
148820\end{array}$ & $\begin{array}{l}\text { * Strachan and Read }\{1994) ; \\
\text { Baldwin et al. }(1995) ; \\
\text { Tassabehji et al. }(1994,1995\}\end{array}$ \\
\hline $\operatorname{Ret}^{d}$ & Ret proto-oncogene & $\mathrm{K}$ & Hirschprung's disease & 142623 & $\begin{array}{l}\text { Schuchardt et al. (1994); * van } \\
\text { Heyningen (1994); } \\
{ }^{\star} \text { Chakravarti (1996) }\end{array}$ \\
\hline Tyr ${ }^{c}$ & Tyrosinase & $\mathrm{C}, \mathrm{R}, \mathrm{S}$ & $\begin{array}{l}\text { Oculocutaneous albinism } \\
\text { type I }\end{array}$ & 203100 & $\begin{array}{l}\text { *Jackson (1994); * Spritz } \\
\text { (1994b); *Barsch (1996) }\end{array}$ \\
\hline Tyrp $1^{b}$ & $\begin{array}{l}\text { Tyrosinase related } \\
\text { protein }\end{array}$ & $\mathrm{C}, \mathrm{R}, \mathrm{S}$ & $\begin{array}{l}\text { Oculocutaneous albinism } \\
\text { type III }\end{array}$ & 203290 & ${ }^{\star} J a c k s o n(1994) ;{ }^{\star}$ Barsh (1996) \\
\hline
\end{tabular}

${ }^{a}$ Abbreviations for creation of mouse mutations; (C) chemically induced; $(K)$ knockout; $(R)$ radiation-induced; (TI) transgene insertion; (TE) transgene expression; (S) spontaneous.

${ }^{\mathrm{b}}$ Reviews are indicated with an asterisk.

${ }^{\mathrm{c}}$ Also called Waardenburg syndrome, type 3.

${ }^{\mathrm{d} A l s o}$ associated with multiple endocrine neoplasia (Table 5).

respectively (Baynash et al. 1994; Hosoda et al. 1994). The Edn3 null phenotype is less severe than that of its receptor, $E d n r b$ : The latter mice are completely white and rarely survive to adulthood because of severe megacolon, whereas the former have some coat pigment and $-15 \%$ of the mice survive because of milder effects on the enteric ganglia. Because Ednrb is activated by two other endothelins (Edn1 and Edn2) in addition to Edn3, these phenotypic differences may reflect the fact that these other ligands can partially compensate for Edn3 deficiency. This hypothesis could be tested by introducing Edn1 or Edn2 mutations into the Edn3 null background. Surprisingly, recent results in mice have suggested that Ednrb may not act in a strictly cellautonomous manner in enteric neuroblasts and may directly affect the intestinal microenvironment (Kapur et al. 1995). Therefore, subtle differences in the microenvironment could play a major role in expressivity of $E d n r b$ mutations in mice and perhaps in HSCR patients as well.
Although Ret, $E d n r b$, and $E d n 3$ are clearly implicated in intestinal aganglionosis in humans and mice, evidence from both species suggests that these are not the only genes involved in this disease. Mice that lack glial cell line-derived neurotrophic factor (Gdnf), the recently identified ligand for Ret, display an identical phenotype to Ret knockout mice (for review, see Massague 1996). In addition, Puffenberger et al. (1994) have reported a genetic modifier of HSCR that maps to chromosome 21q22. Likewise, Pavan et al. (1995) have mapped six genetic modifiers of the $s$ phenotype. Whether these genes directly modify the incidence or severity of megacolon remains to be determined.

\section{Piebald trait}

Mutations in Kit, a receptor tyrosine kinase, cause PT in humans and Dominant spotting $(W)$ in mice (for review, 
see Besmer et al. 1993; Fleischman 1993|. At least 57 different $W$ alleles have been identified. In heterozygous mice, most $W$ mutants have spots of hypopigmentation on the head and ventrum, a phenotype strikingly similar to PT. In homozygous mice, the severe $W$ mutations cause embryonic lethality (resulting from severe effects on erythropoiesis) while milder mutations allow viability but the mice are anemic, sterile, and deaf, and have extensive hypopigmentation and reduced muscle contractions in the gut (Besmer et al. 1993; Huizinga et al. 1995). In both humans and mice (Fig. 2), all point mutations in Kit that produce a phenotype localize to the tyrosine kinase domain. In general, mutations in the mouse that abolish Kit activity are homozygous lethal, whereas mutations that reduce, but don't abolish, tyrosine kinase activity are homozygous viable. Interestingly, mice heterozygous for a dominant negative $W$ allele $\left(W^{37}\right.$, see Fig. 2) have severe defects in pigmentation and are anemic, but a human with an identical mutation is hypopigmented but is not anemic (Fleischman 1992). Additionally, $W$ homozygous mice are deaf because of a reduction or absence of melanocytes of the inner ear (for review, see Steel 1995) whereas humans with PT display no apparent defects in hearing, nor are they sterile or anemic.

The phenotype of $W$ mutant mice is identical to that of mice carrying mutations at the Steel (SI) locus, which encodes mast cell growth factor (Mgf), the ligand for Kit (for review, see Besmer et al. 1993). Surprisingly, Mgf mutations have not been identified in humans with PT (Ezoe et al. 1995). Whether this reflects different functions of $\mathrm{Mgf}$ in mice versus humans has not been determined.

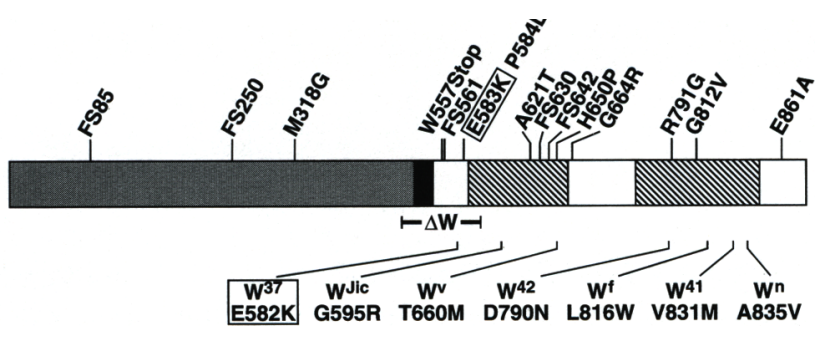

Figure 2. Mutations in Kit that have been identified in humans with PT (top) and in mice with different $W$ alleles (bottom). The different domains of the protein are as follows: the extracellular domain is shaded, the transmembrane domain is black, and the split kinase domains are hatched. For point mutations, the amino acid residue affected by each mutation is indicated with the one-letter abbreviation for the normal and mutant residue; e.g., M318G is a mutation that replaces methionine with glycine at amino acid 318 . Stop is a termination codon created by the point mutation. The boxed mutations are identical in mice and humans (note that amino acid 583 in humans corresponds to amino acid 582 in mice). The positions of frameshift mutations (FS) are indicated at the last amino acid of the wild-type protein. For the $W$ allele, the solid line indicates the extent of an in frame deletion. The M318G mutation is thought to be silent. See Spritz (1994a) and Ezoe et al. (1995) for human KIT mutations and Besmer et al. \{1993\} for a review of mouse Kit mutations.

\section{Waardenburg syndrome}

WS is a dominant pigmentation disorder that occurs with congenital deafness. Three types of WS have been described. WS1 (MIM 193500) is distinguished from WS2 (MIM 193510) by dystopia canthorum, a lateral displacement of the inner canthi of the eye, whereas WS3 (MIM 148820 , also called Klein-Waardenburg syndromel is a severe form of WS1 that involves WS1 symptoms plus upper limb anomalies. Like HSCR, WS is genetically heterogeneous. Mutations in two transcription factors, paired box gene-3 (PAX3) and microphthalmia transcription factor (MITF), cause each of the different types of WS. More than 30 PAX3 mutations that affect virtually every domain of the protein have been found in WS1 and WS3 patients (Baldwin et al. 1995; Tassabehji et al. 1995). Strikingly, each of these mutations, whether a point mutation or a deletion of the entire gene, results in a very similar phenotype that may be explained by $b . p$ loinsufficiency. Approximately $20 \%$ of WS2 patients contain mutations in MITF (Tassabehii et al. 1995). For both PAX3 and MITF, humans appear to be more sensitive than mice to gene dosage effects (Jackson and Raymond 1994; Tassabehji et al. 1995); however, the reasons for these differences are not known.

In mice, Pax3 is encoded by the splotch $(S p)$ locus (for review, see Strachan and Read 1994). At least six $S p$ alleles are available for study and all cause white spotting in the abdomen, tail, and feet in the heterozygous condition. The $S p$ homozygous phenotype varies with different alleles. Mice homozygous for $S p$ null alleles $(S p$ and $S p^{2 H}$ ) die midway through gestation with defects in the neural tube and spinal ganglia, whereas mice homozygous for a hypomorphic $S p$ allele $\left(S p^{d}\right)$ may survive to birth but have spina bifida and absent or abnormal spinal ganglia. Mutations analogous to several of these $S p$ alleles have been described in humans (Tassabehji et al. 1994); however, there is an important interspecies difference in phenotype: All WS patients that are heterozygous for $P A X 3$ mutations have hearing loss, whereas $S p$ heterozygous mice have normal hearing and no anatomical or physiological defects in the inner ear (Steel and Smith 1992). In addition, an individual homozygous for a severe PAX3 mutation has lived at least 3 months and did not display any neural tube defects (Zlotogora et al. 1995).

Mitf is encoded by the mouse microphthalmia (mi) locus (for review, see Jackson and Raymond 1994; Moore 1995). The mi locus is particularly fascinating because there are many alleles available for study and the various alleles display a plethora of phenotypic consequences and complex inheritance patterns. All mi alleles cause defects in melanocytes that lead to pigmentation and deafness in homozygotes, yet certain alleles affect other cell types including the retinal pigmented epithelium, mast cells, basophils, natural killer cells, macrophages, and osteoclast precursors. In general, the more severe alleles are semidominant and the less severe alleles are recessive and the mutations in each class localize to specific domains. Interestingly, a mutation identical to that 
of the original mutation at this locus, the mi allele, was found in a WS2 family (see Fig. 3). Heterozygous mi/+ mice display coat pigmentation defects and have normal hearing; however, humans with the analogous mutation have a phenotype that resembles albinism-deafness rather than classical WS2 (Tassabehii et al. 1995). Similarly, patients heterozygous for mutations that would be expected to be recessive (such as functional nulls) have hearing deficiencies, whereas the only heterozygous hearing deficiencies observed in mice are caused by a severe, dominant negative allele of $\mathrm{mi}\left(\mathrm{Mi}^{\mathrm{wh}}\right.$ ) (for review, see Steel 1995).

\section{Disorders of hearing and vision}

Many functional and anatomical similarities exist in the eyes and ears of mice and humans, making the mouse an ex 'ellent model system for human disorders of these tissues. In addition, a large genetic reservoir of potential human disease models is provided by the $>150$ different mutant loci that affect eyes or ears of the mouse (MGD). In Table 2, six mouse models of eye diseases and one mouse model of a hearing deficiency are described. All of these are excellent models of human disease, as each bears striking similarities to the human phenotype. Pax3, Mitf, Cola1, Pmp22, and Gus also cause hearing defects in addition to other abnormalities (for review, see

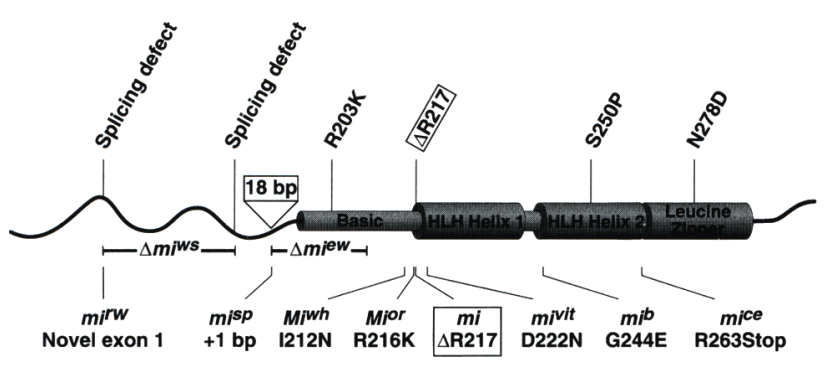

Figure 3. Mutations in Mitf that have been identified in WS2 patients (top) and in mice with different mi alleles (bottom). The different domains of this transcription factor and an alternatively spliced exon of $18 \mathrm{bp}$, which affects the affinity of Mitf for DNA, are shown. For point mutations, the amino acid affected by each mutation is indicated with the one-letter abbreviation for the normal and mutant residue; e.g., R203K is a mutation that replaces arginine with lysine at amino acid 203. In humans, the splicing defects in the 5' end of the MITF mRNA result from point mutations and are predicted to be null alleles. The boxed mutations are identical in mice and humans (an in-frame deletion of one amino acid in each case). The $m i^{r \omega}$ allele carries a deletion of $5^{\prime}$ flanking sequences that causes transcription to initiate at a cryptic site and the mRNA is then spliced to the normal exon 2 Mitf mRNA. For the $m i^{w s}$ and $m i^{e w}$ alleles, the solid lines indicate the extent of the in-frame deletions. The $m i^{\text {sp }}$ allele has a splicing defect that affects only the 18-bp alternatively spliced product. Stop is a termination codon created by the point mutation. These data are from Jackson and Raymond (1994), Moore (1995), Tassabehji et al. (1995), and Steingrímsson et al. (1996).
Steel and Brown 1994; Steel 1995) and are described elsewhere in this review (see Tables 1, 3, and 4).

\section{Disorders of retinal development}

Aniridia is a developmental defect of the eye that results from hypoplasia of the iris (MIM 106210). The human aniridia gene was shown to be $P A X 6$, a paired domain transcription factor, and subsequent studies revealed that the homologous gene is affected in small eye (Sey) mice (for review, see Hanson and van Heyningen 1995). Since these initial reports, PAX6 mutations have also been associated with anterior segment malformations, such as Peter's anomaly (MIM 261540; Hanson et al. 1994) and a range of other ocular defects (Glaser et al. 1994).

Gene dosage appears to be critical to Pax6 function in both mice and humans as deletions and null point mutations are semidominant and homozygosity results in an even more severe phenotype (for review, see Hanson and Van Heyningen 1995). Interestingly, eye development is sensitive to increased, as well as decreased, expression of $P A X 6$. This was demonstrated elegantly by Schedl et al. (1996), who used YAC transgenic experiments to investigate gene dosage effects of PAX6. Although YACs containing wild-type $P A X 6$ were able to rescue the Sey mutant phenotype, they caused severe microphthalmia and cataracts when present in the wildtype background. Furthermore, by analyzing Sey/Sey+ + chimeras, Quinn et al. (1996) have provided evidence that normal eye development requires a threshold number of normal cells. Thus, somatically acquired rearrangements that affect $P A X 6$ expression, either positively or negatively, could have dramatic effects on eye development.

\section{Degenerative disorders of the retina}

The stimulation of photoreceptors in the retina by light results in electrical signals that are transmitted to the brain. Mutations in three components of this phototransduction system cause degeneration of the photoreceptor cells that ultimately leads to blindness: Rhodop$\sin (\mathrm{Rho})$ is a G protein-coupled photoreceptor that mediates vision at low light levels; peripherin ( $\operatorname{Prph} 2)$ is a transmembrane glycoprotein that may be important for the assembly and stability of membranous disks of the outer segment of photoreceptors; and the $\beta$-subunit of rod cGMP phosphodiesterase (Pdeb) is a component of the key regulator of CGMP-gated cation channels that are involved in phototransduction.

Retinitis pigmentosa (RP; MIM 268000) is a heterogeneous group of disorders that are the most common causes of blindness in middle-aged individuals. X-linked, autosomal recessive (ar) and autosomal dominant (ad) forms of RP have been reported. Mutations in RHO have been associated with both adRP and arRP (for review, see McInnes and Bascom 1992). Because null alleles cause arRP and point mutations cause adRP, it has been proposed that the latter mutations cause gain of function 
Table 2. Disorders of vision and hearing

\begin{tabular}{|c|c|c|c|c|c|}
\hline $\begin{array}{l}\text { Mouse } \\
\text { gene } \\
\text { symbol }\end{array}$ & Gene name & $\begin{array}{l}\text { Mouse } \\
\text { model }^{\text {a }}\end{array}$ & Human disease & MIM no. & Selected references ${ }^{a}$ \\
\hline Myo7ash1 & Myosin VIIA & $\mathrm{C}, \mathrm{S}$ & Ushers syndrome type IB & 276903 & $\begin{array}{l}\text { Gibson et al. (1995); Weil et al. } \\
\text { (1995) }\end{array}$ \\
\hline Oat & $\begin{array}{l}\text { Ornithine amino } \\
\text { transferase }\end{array}$ & $\mathrm{K}$ & $\begin{array}{l}\text { Hypo-ornithinemia with } \\
\text { gyrate atrophy of choroid } \\
\text { and retina }\end{array}$ & 258870 & $\begin{array}{l}{ }^{*} \text { Valle and Simell (1995); Wang } \\
\text { et al. }(1995)\end{array}$ \\
\hline $\operatorname{Pax} 2^{\mathrm{Krd}}$ & $\begin{array}{l}\text { Paired box homeotic } \\
\text { gene } 2\end{array}$ & TI & $\begin{array}{l}\text { Optic nerve coloboma } \\
\text { w/renal disease }\end{array}$ & 120330 & $\begin{array}{l}\text { Keller et al. (1994); Sanyanusin } \\
\text { et al. (1995) }\end{array}$ \\
\hline $\operatorname{Pax} 6^{\mathrm{SeV}}$ & $\begin{array}{l}\text { Paired box homeotic } \\
\text { gene } 6\end{array}$ & $\mathrm{C}, \mathrm{R}, \mathrm{S}$ & Aniridia type II & 106210 & ${ }^{\star}$ Hanson and Van Heyningen \\
\hline$P d e b^{r d 1}$ & $\begin{array}{l}\text { Phosphodiesterase, } \\
\text { cGMP, rod receptor, } \\
\text { beta }\end{array}$ & $S$ & $\begin{array}{l}\text { Autosomal recessive } \\
\text { retinitis pigmentosa }\end{array}$ & 180072 & $\begin{array}{l}\text { Bowes et al. (1990); McLaughlin } \\
\text { et al. (1993, 1995); Gal et al. } \\
\text { (1994) }\end{array}$ \\
\hline $\operatorname{Prph2^{Rd2}}$ & Peripherin 2 & $S$ & Retinal degeneration, slow & 179605 & $\begin{array}{l}\text { *Travis and Hepler (1993); Ma } \\
\text { et al. }(1995)\end{array}$ \\
\hline Rho & Rhodopsin & $\mathrm{TE}$ & Retinitis pigmentosa- 4 & 180380 & $\begin{array}{l}\text { *McInnes and Bascom (1992); } \\
\text { Naash et al. (1993); Sung et } \\
\text { al. (1994) }\end{array}$ \\
\hline
\end{tabular}

Mutations in $\operatorname{Pax}^{S^{P}}$ and Mitf $^{m i}$ (Table 1), Cola1 ${ }^{\text {Mov13 }}$ (Table 3), Pmp22 ${ }^{\text {Tr }}$ (Table 4), and Gus ${ }^{m p s}$ (Table 7) also cause hearing defects (for review, see Steel and Brown 1994; Steel 1995).

asee Table 1 for footnote.

(GOF) that in some way induces degeneration of photoreceptor cells. In support of this hypothesis, various mouse models that express mutant Rho proteins induce similar photoreceptor degeneration. These transgenic mouse models also have been used to examine the mechanism of and possible environmental effects on photoreceptor degeneration. Huang et al. (1993) showed that the Rho phenotype is non cell-autonomous in mice that are chimeric for nontransgenic and transgenic cells. Thus, some form of interaction must be occurring between wild-type and mutant cells that induces cellular death in both populations. By comparing the rate of photoreceptor degeneration in mice containing mutant $R$ ho transgenes that were raised in the dark or in alternating light/dark cycles, Naash et al. (1996) have proposed that the vision of RP patients may be prolonged by minimizing light exposure.

The first mutations in Prph2 were identified in retinal degeneration-2 $(R d 2$, previously called retinal degeneration slow, rds) mice (Travis et al. 1989). Rd2 is a semidominant trait that causes degeneration of both rod and cone photoreceptors. As the only allele at this locus appears to be null as a result of the insertion of a repetitive element (Ma et al. 1995), the semidominant inheritance of $R d s$ is thought to result from haploinsufficiency. In humans, PRPH2 mutations have been associated with a variety of phenotypes that are each caused by different types of mutations (for review, see Travis and Hepler 1993). Because adRP has been associated with null $P R P H 2$ alleles, the $r d s$ mouse is a good model for this form of retinopathy. Surprisingly, a large amount of phenotypic variation has been seen in humans with different PRPH2 mutations. Construction of mice with analogous mutations in Prph2, either through ES cell technology or through transgene engineering, and the introduction of these mutations into different genetic backgrounds, will be useful to sort out the effects of potential modifying factors on the function of this gene.

One of the most important models for the study of RP is the retinal degeneration-1 (rd1) mouse, in which all photoreceptor cells have degenerated in homozygous mice by four weeks of age. Many of the commonly used inbred strains, including $\mathrm{C} 3 \mathrm{H}$ and its derivatives and CBA/J, are homozygous for $r d 1$. Mutations in the Pdeb gene were first identified in $r d 1$ mice (Bowes et al. 1990; Pittler et al. 1991) and subsequently in humans with arRP (McLaughlin et al. 1993, 1995) and a dominant form of night blindness (Gal et al. 1994). Two mutations in the $P d e b$ gene of $r d 1$ mice have been identified: a nonsense mutation that causes truncation of the protein (Bowes et al. 1990) and intronic insertion of an endogenous mouse leukemia virus $(X m v 28)$ that causes a transcriptional defect (Bowes et al. 1993). Xmv28 has also been found in strains derived from wild mice, as well as from inbred laboratory strains that are not known to have recent common origins (Bowes et al. 1993). This suggests a surprisingly high degree of evolutionary stability for a mutation that causes loss of vision in the mice.

A potentially useful treatment for retinal degeneration has been tested in rd1 mice (Bennett et al. 1996). Recombinant defective adenoviruses that carry the wild-type $P d e b$ gene were introduced into the retinas of $r d 1$ mice before the onset of photoreceptor degeneration and found to significantly delay photoreceptor cell death. These mouse models are thus proving to be very useful for testing various treatment vehicles and regimens for retinal degeneration.

Recent evidence obtained by gene targeting in mice 
has revealed the importance of the gamma subunit of rod cGMP phosphodiesterase (Pdeg) to retinal disease. Tsang et al. (1996) have disrupted the Pdeg gene and found that homozygous mice display a phenotype of retinal degeneration virtually identical to that of $r d 1$ mice and arRP. Unlike other mouse models, introduction of the Pdeg mutation into a variety of different genetic backgrounds did not affect the mutant phenotype. A possible role for this gene in human retinal diseases should be investigated.

\section{Hearing disorders}

Deafness may be grouped into several categories, depending on the primary site of the defect in the auditory system (Steel and Brown 1994; Steel 1995). In humans, the most common type of hearing abnormality is caused by defects in the sensory neuroepithelium, particularly in the organ of Corti, that is responsible for normal auditory transduction. Because the majority of these cases are recessive and nonsyndromic and involve numerous genes, linkage analysis of this form of hearing defect has been difficult to perform in humans.

A landmark in our understanding of hearing disorders was the cloning in 1995 of the first gene involved in auditory transduction and the mouse played an integral role in this endeavor. Comparative mapping and phenotypic similarities had suggested that the mouse shaker 1 (sh1) deafness mutation is homologous to Usher syndrome type 1B (USHIB; MIM 276903), the most common form of deaf-blindness in humans. Gibson et al. (1995) used a positional cloning strategy to show that an unconventional myosin (Myo7a) is encoded at the sh1 locus. Once the mouse gene was cloned, it was then fairly straightforward to analyze and find MYO7A mutations in USHIB patients (Weil et al. 1995). Although degeneration of the organ of Corti occurs in both sh1 mice and USH1B patients, only the latter display retinal degeneration. Currently it is unclear whether these interspecies differences are attributable to the nature of the mutations or to differences in function or compensation of defective Myo7a. Recently, a second unconventional myosin (Myo6) has been shown to be mutated in Snell's waltzer mice, which also have defects in the sensory neuroepithelium of the ear (Avraham et al. 1995). Unconventional myosins, as well as the numerous accessory proteins that interact with these cytoskeletal proteins, are thus likely candidate genes for other loci involved in neuroepithelial deafness.

\section{Disorders of bone, cartilage, and skin}

In the mouse, there are $>100$ genetically defined loci and transgenic models that affect skeletal development (MGD). A wide range of skeletal abnormalities have been found in mice and humans that result from patterning defects during embryogenesis, failure to establish the correct proportions of bone growth, and alterations in the biomechanical properties of bone. In Table 3,13 genes are listed in which alterations in both human and mouse homologs disrupt skeletal development. In addition, three keratin genes are listed in this table that cause skin disorders. With the exception of mutants in alkaline phosphatase-2 (Akp2), all of the mouse models have phenotypic consequences that closely mimic or explain some aspect of the corresponding human disease.

\section{Polydactyly}

Mutations in Hoxd13 and Gli3, which are members of the homeodomain and zinc-finger families of transcription factors, respectively, cause pattern deformities of the skeleton of mice and humans. Mice that are homozygous for null Hoxd13 mutations display mild skeletal abnormalities along all body axes and reduced loss of phalanges, bone fusions, and duplications in the limbs (Dolle et al. 1993). In humans, the candidate gene approach was used to identify mutations in HOXD13 that cosegregated with synpolydactyly trait (MIM 186000), an autosomal dominant trait characterized by both webbing between fingers and duplication of fingers. The mutation in these patients involves expansion of a polyalanine tract near the amino terminus of the protein (Muragaki et al. 1996b). Although the homozygous phenotype of Hoxd13 mice is milder than that of synpolydactyly patients, some aspects of the mutant phenotype overlap in the two species. However, unlike humans with synpolydactyly, the Hoxd13 heterozygous mice do not have an apparent phenotype.

\section{Skeletal dysplasia: Fgfr mutations}

Cell-cell signaling via fibroblast growth factor receptors (FGFRs) has been shown recently to be involved in coordinating the growth of endochondral and intramembranous bones. Disruption of the proportional growth of the radial and longitudinal axes of endochondral bones results in skeletal dysplasias. In the skull, bone deposition and growth of intramembranous bones is coordinated temporally with suture closure, and various abnormalities, known as craniosynostoses, result from premature suture closure.

Point mutations in FGFR1 and FGFR2 have been associated with Pfeiffer, Jackson-Weiss, and Crouzon syndromes: All three syndromes are autosomal dominant craniosynostosis syndromes that also exhibit variable degrees of limb abnormalities (for review, see Muenke and Schell 1995). Because mice heterozygous for Fgfr1 null mutations are normal, and homozygosity causes early embryonic lethality (Deng et al. 1994; Yamaguchi et al. 1994), the human mutations have been postulated to express GOF gene products. Mouse transgenics that recapitulate the human mutations will be useful models for the human diseases.

Although FGFR1 and FGFR2 mutations affect intramembranous bones, mutations in FGFR3 generally affect endochondral bones (for review, see Muenke and Schell 1995). Three dominant skeletal dysplasias that represent a graded series of phenotypic severity have been associated with FGFR3 mutations (Bellus et al. 
Table 3. Diseases of bone, skin, and connective tissue

\begin{tabular}{|c|c|c|c|c|c|}
\hline $\begin{array}{l}\text { Mouse } \\
\text { gene } \\
\text { symbol }\end{array}$ & Gene name & $\begin{array}{l}\text { Mouse } \\
\text { model }^{\mathrm{a}}\end{array}$ & Human disease & MIM no. & Selected references ${ }^{a}$ \\
\hline Akp2 & $\begin{array}{l}\text { Alkaline } \\
\text { phosphatase-2, liver }\end{array}$ & $\mathrm{K}$ & Hypophosphatasia & 171760 & $\begin{array}{l}\text { Henthorn et al. }(1992) ; \\
\quad \text { Waymire et al. (1995) }\end{array}$ \\
\hline Cola1 $1^{\text {Mov13 }}$ & $\begin{array}{l}\text { Procollagen type } 1, \\
\text { alpha } 1\end{array}$ & $\mathrm{~K}, \mathrm{RI}, \mathrm{TE}$ & $\begin{array}{l}\text { Osteogenesis imperfecta; } \\
\text { Ehlers-Danlos type VII }\end{array}$ & $\begin{array}{l}130060 \\
166200\end{array}$ & $\begin{array}{l}\text { Liu et al. }(1995 a)_{i}{ }^{\star} \text { Prockop and } \\
\text { Kivirikko }(1995)\end{array}$ \\
\hline Colla $2^{\text {oim }}$ & $\begin{array}{l}\text { Procollagen type } 1, \\
\text { alpha } 2\end{array}$ & $\mathrm{~S}$ & $\begin{array}{l}\text { Osteogenesis imperfecta; } \\
\text { Ehlers-Danlos type VII }\end{array}$ & $\begin{array}{l}130060 \\
166200\end{array}$ & $\begin{array}{l}\text { Chipman et al. (1993); } \\
\text { ^Prockop and Kivirikko } \\
\text { (1995) }\end{array}$ \\
\hline Col2a1 & $\begin{array}{l}\text { Procollagen type } 2, \\
\text { alpha } 1\end{array}$ & $\mathrm{~K}, \mathrm{TE}$ & $\begin{array}{l}\text { Spondyloepiphyseal dysplasia; } \\
\text { achondrogenesis type } 2 \\
\text { spondyloepimetaphyseal } \\
\text { dysplasia }\end{array}$ & $\begin{array}{l}183900 \\
200610 \\
184250\end{array}$ & $\begin{array}{l}\text { Hiltunen et al. (1994); }{ }^{\star} \text { Vikkula } \\
\text { et al. (1994); Li et al. (1995a) }\end{array}$ \\
\hline Col5a2 & $\begin{array}{l}\text { Procollagen type } 5, \\
\text { alpha } 2\end{array}$ & $\mathrm{~K}$ & Ehlers-Danlos type & 130000 & $\begin{array}{l}\text { Andrikopolous et al. (1995); } \\
\text { Toriello et al. }(1996)\end{array}$ \\
\hline Col9a1 & $\begin{array}{l}\text { Procollagen type } 9, \\
\text { alpha } 1\end{array}$ & $\mathrm{~K}, \mathrm{TE}$ & Multiple epiphyseal dysplasia $2^{\mathrm{d}}$ & 600204 & $\begin{array}{l}\text { Nakata et al. (1993); Fässler et } \\
\text { al. (1994); Muragaki et al. } \\
\text { (1996a) }\end{array}$ \\
\hline Colloal & $\begin{array}{l}\text { Procollagen type } 10, \\
\text { alpha } 1\end{array}$ & $\mathrm{~K}, \mathrm{TE}$ & $\begin{array}{l}\text { Schmid metaphyseal } \\
\text { chondrodysplasia }\end{array}$ & 156500 & $\begin{array}{l}{ }^{\star} \text { Olsen }\left\{1995 \text { ); }{ }^{\star} \text { Prockop and }\right. \\
\text { Kivirikko (1995) }\end{array}$ \\
\hline Col11a $1^{\text {cho }}$ & $\begin{array}{l}\text { Procollagen type } 11 \\
\text { alpha } 1\end{array}$ & $\mathrm{~K}, \mathrm{~S}$ & Stickler syndrome type $\mathrm{II}^{\mathrm{e}}$ & 184840 & $\begin{array}{l}\text { Li et al. (1995b); }{ }^{*} \text { Olsen (1995); } \\
\text { Vikkula et al. (1995) }\end{array}$ \\
\hline Fgfr1 & $\begin{array}{l}\text { Fibroblast growth } \\
\text { factor receptor } 1\end{array}$ & $\mathrm{~K}$ & Acrocephalopolysyndactyly type $\mathrm{V}^{\mathrm{f}}$ & 101600 & $\begin{array}{l}\text { Deng et al. (1994); Yamaguchi } \\
\text { et al. }(1994) ;{ }^{\star} \text { Muenke and } \\
\text { Schell }(1995)\end{array}$ \\
\hline Fgfr3 & $\begin{array}{l}\text { Fibroblast growth } \\
\text { factor receptor } 3\end{array}$ & $\mathrm{~K}$ & $\begin{array}{l}\text { Achondroplasia; } \\
\text { hypochondroplasia; } \\
\text { thanatophoric dwarfism }\end{array}$ & 134934 & $\begin{array}{l}\text { Bellus et al. (1995); }{ }^{\star} \text { Muenke } \\
\text { and Schell (1995); Colvin et } \\
\text { al. (1996); Deng et al. (1996); } \\
\text { Naski et al. (1996) }\end{array}$ \\
\hline$F b n 1^{T s k}$ & Fibrillin & S & Marfans syndrome & 154700 & $\begin{array}{l}\text { *Ramirez (1996); Siracusa et al. } \\
\text { (1996) }\end{array}$ \\
\hline Gli3 $^{X t}$ & $\begin{array}{l}\text { GLI-Kruppel family } \\
\text { member }\end{array}$ & $\mathrm{R}, \mathrm{S}$ & $\begin{array}{l}\text { Greig cephalopolysyndactyly } \\
\text { syndrome }\end{array}$ & 175700 & $\begin{array}{l}\text { Vortkamp et al. (1991); Hui and } \\
\text { Joyner (1993) }\end{array}$ \\
\hline Hoxd13 & Homeo box D13 & $\mathrm{K}$ & Syndactyly type II & 186000 & $\begin{array}{l}\text { Dolle et al. (1993); Muragaki et } \\
\text { al. (1996b) }\end{array}$ \\
\hline Krt $1-10$ & $\begin{array}{l}\text { Keratin complex-1, } \\
\text { acidic, gene } 10\end{array}$ & $\mathrm{~K}, \mathrm{TE}$ & $\begin{array}{l}\text { Bullous erythroderma } \\
\text { ichthyosiformis congenita }\end{array}$ & 113800 & $\begin{array}{l}{ }^{\star} \text { Fuchs (1995); Porter et al. } \\
\text { (1996) }\end{array}$ \\
\hline Krt1-14 & $\begin{array}{l}\text { Keratin complex-1, } \\
\text { acidic, gene } 14\end{array}$ & $\mathrm{~K}, \mathrm{TE}$ & Epidermolysis bullosa simplex & 148066 & $\begin{array}{l}{ }^{\star} \text { Fuchs (1995); Lloyd et al. } \\
\text { (1995) }\end{array}$ \\
\hline Krt1-16 & $\begin{array}{l}\text { Keratin complex-1, } \\
\text { acidic, gene } 16\end{array}$ & $\mathrm{TE}$ & $\begin{array}{l}\text { Nonepidermolytic palmoplantar } \\
\text { keratoderma; pachyonychia } \\
\text { congenita }\end{array}$ & 148067 & $\begin{array}{l}\text { Takahashi et al. (1994a); }{ }^{\star} \text { Fuchs } \\
\text { (1995) }\end{array}$ \\
\hline
\end{tabular}

${ }^{a}$ See Table 1 for footnotes.

${ }^{\mathrm{b}}$ Mutations are in COL1A1 or COL1A2 gene.

${ }^{\mathrm{c}}$ Mutations are in COL5A1 gene.

${ }^{\mathrm{d}}$ Mutations are in COL9A2 gene.

'Mutations are in COL11A1 or COL11A2 gene.

${ }^{\mathrm{f}}$ Also called Pfeiffer syndrome.

1995; Naski et al. 1996). The most severe is thanatophoric dysplasia (TD; MIM 187600), which causes profound dwarfism and neonatal lethality in heterozygotes; achondrodysplasia (MIM 100800) has less severe dwarfism and is nonlethal; and hypochondroplasia (MIM 146000 ) has the mildest skeletal defects. In each of these diseases, the lack of epiphyseal growth relative to periosteal growth causes abnormally short and wide bones. Each of these different syndromes results from point mutations in specific domains of FGFR3 (Bellus et al. 1995; Muenke and Schell 1995; Naski et al. 1996).
Compelling genetic evidence that all of the human FGFR3 mutations result in the constitutive activation of FGFR3 comes from studies of mice. Mice heterozygous for null mutations in Fgfr3 are normal, yet homozygous mice show a phenotype that is the opposite of human FGFR3 mutations (Colvin et al. 1996; Deng et al. 1996); that is, the Fgfr3-deficient mice exhibit overgrowth of the long bones rather than decreased growth. These results have suggested that $F g f r 3$ is a negative regulator of bone growth. Furthermore, Fgfr3-deficient mice are profoundly deaf owing to abnormalities in the organ of Corti 
(Colvin et al. 1996), suggesting that FGFR3 mutations in humans may be associated with hearing loss as well as skeletal abnormalities.

\section{Skeletal dysplasia: Collagen mutants}

Collagens are the main fibrous proteins of connective tissue and are the most abundant proteins of the extracellular matrix. There are at least 19 different collagens (Prockop and Kivirikko 1995) that are formed into a triple helix of three pro- $\alpha$ polypeptide chains; some collagens are comprised of three of the same pro- $\alpha$ chains while other collagens are heterotrimers, composed of two or more different pro- $\alpha$ chains. Thus, mutations in different collagen genes may disrupt the same collagen fibril. In humans, mutations in 13 different collagen genes have been associated with disease phenotypes (Olsen 1995; Prockop and Kivirikko 1995). Different human diseases can also result from mutations in the same collagen gene. For example, at least five different forms of chondrodysplasia and cartilage degeneration result from mutations in the COL2A1 gene (Vikkula et al. 1994).

In one case, a mouse collagen mutant was instrumental in identifying the corresponding human disease gene. Using a candidate gene approach, Li et al. (1995b) showed that mutations in the gene encoding procollagen type 11 , $\alpha 1$ (Col11a1) are responsible for the skeletal defects in chondrodysplasia (cho) mice. The phenotypic similarity between cho mice and certain human chondrodysplasias, such as Stickler syndrome (MIM 184840), and the close linkage between CO111A2 and autosomal dominant Stickler syndrome led to the identification of COL11A2 mutations in Stickler syndrome patients (Vikkula et al. 1995). In addition to cho mice, mouse models for mutations in six other human collagen genes have been reported (see Table 3). The localization of the defects in the developing bone caused by each of these mutations, as well as for Fgfr3, is illustrated in Figure 4. These models were derived in a variety of ways including disruption by a retroviral provirus (Cola1), spontaneously occurring mutations [osteogenesis imperfecta (Col1a2)] and transgenic and/or knockout models (Cola1, Col2a1, Colsa2, Col9a1, and Col10a1).

\section{Neurological and neuromuscular disorders}

There are at least 150 different mutant loci in the mouse that cause neurological, neuromuscular or behavioral defects (MGD). Twenty-two of these mutant loci are models for human disease and are shown in Table 4. Sixteen of these models cause neurological phenotypes and the remaining six cause neuromuscular or muscular abnormalities. With the exception of the $H d h$ deficient mouse, all of the mouse models described in Table 4 share many phenotypic similarities with corresponding human disease.

\section{Neurodegenerative disorders: Alzheimer's}

The fourth leading cause of death in developed countries is Alzheimer's disease (AD; MIM 104300), a progressive

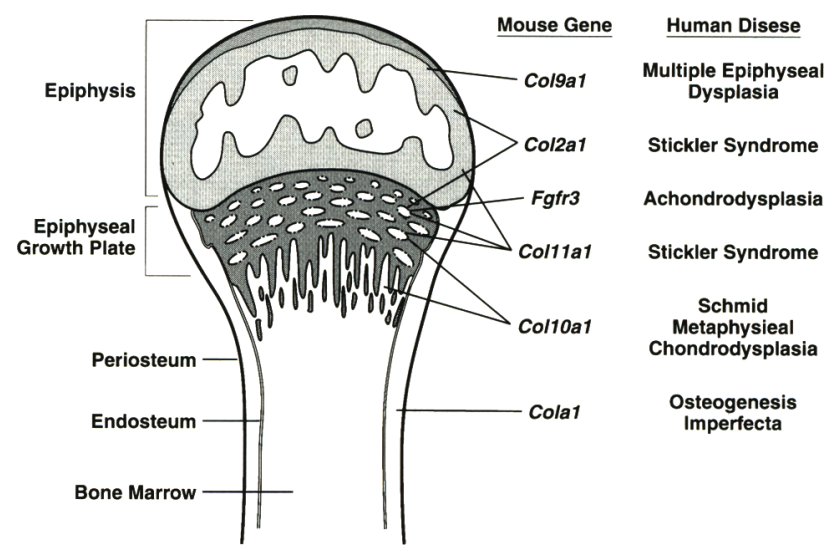

Figure 4. The sites in long bones that are affected by mutant genes in various mouse models of human skeletal diseases. Because some collagen fibrils are composed of two or more pro- $\alpha$ chains that are encoded by different genes, mutations in different collagen genes may disrupt the same collagen fibril. Thus, some of the mouse models shown may not contain mutations in the homologous gene, e.g., the COL9A2 gene is mutated in multiple epiphyseal dysplasia whereas the correponding mouse model involves alterations of Col9a1.

dementia that can be caused by mutations in at least four genes (for review, see Pericak-Vance and Haines 1995). In the central nervous system (CNS) of AD patients, neuronal degeneration in specific regions of the brain leads to loss of memory and cognitive abilities. Two histopathological hallmarks of $\mathrm{AD}$ are the accumulation of extracellular senile plaques and intracellular neurofibrillary tangles, which consist primarily of $\mathrm{A} \beta$ protein /also called $\beta$-amyloid) and abnormally phosphorylated tau protein, respectively. $A \beta$ is derived from amyloid beta precursor protein (APP), and both increased gene dosage and intragenic mutations in the $A P P$ gene have been associated with $\mathrm{AD}$ (Pericak-Vance and Haines 1995). A second major risk factor for $\mathrm{AD}$ is apolipoprotein $\mathrm{E}$ (APOE). Of three different APOE isoforms found in humans, one $\left(\mathrm{APOE}^{\star} \mathrm{E} 4\right)$ is associated with increased risk and decreased age of onset of $\mathrm{AD}$ (for review, see Strittmatter and Roses 1995). Although there is evidence that $A P P$ mutations may lead to abnormal processing and higher levels of $A \beta$, and that the APOE isoforms differ with respect to binding to tau protein and $A \beta$, the mechanisms by which these proteins contribute to $\mathrm{AD}$ pathogenesis are currently obscure.

Recently, several laboratories have produced transgenic mice that exhibit many of the pathological changes associated with $\mathrm{AD}$. This occurs with transgenes that express high levels of wild-type A $\beta$ (LaFerla et al. 1995) or APP that has a point mutation found in $\mathrm{AD}$ patients (Games et al. 1995). Both models share striking similarities to AD patients; however, senile plaques were observed only in the latter model and neither model developed neurofibrillary tangles. Although the reasons for this are not known and warrant further investigation, these results in mice suggest that the plaques and tangles 
Bedell et al.

Table 4. Neurological and neuromuscular disorders

\begin{tabular}{|c|c|c|c|c|c|}
\hline $\begin{array}{l}\text { Mouse } \\
\text { gene } \\
\text { symbol }\end{array}$ & Gene name & $\begin{array}{l}\text { Mouse } \\
\text { model }^{a}\end{array}$ & Human disease & MIM no. & Selected references ${ }^{a}$ \\
\hline$A p o e^{\mathrm{b}}$ & Apolipoprotein $\mathrm{E}$ & $\mathrm{K}$ & Alzheimer disease-2 & 104310 & $\begin{array}{l}\text { Masliah et al. (1995); } \\
\text { ^Pericak-Vance and Haines } \\
(1995) ;{ }^{\star} \text { Strittmatter and Roses } \\
\text { (1995) }\end{array}$ \\
\hline App & $\begin{array}{l}\text { Amyloid beta precursor } \\
\text { protein }\end{array}$ & $\mathrm{K}, \mathrm{TE}$ & Alzheimer disease & 104300 & $\begin{array}{l}\text { Müller et al. (1994); Games et al. } \\
\text { (1995); LaFerla et al. (1995); } \\
\quad{ }^{\star P e r i c a k-V a n c e ~ a n d ~ H a i n e s ~} \\
\text { (1995); Zheng et al. (1995) }\end{array}$ \\
\hline Atm & Ataxia telangiectasia & $\mathrm{K}$ & Ataxia telangiectasia & 208900 & $\begin{array}{l}\text { Savitsky et al. (1995); Barlow et } \\
\text { al. (1996) }\end{array}$ \\
\hline $\operatorname{Cchl1a3^{mdg}}$ & $\begin{array}{l}\text { Calcium channel, L type, } \\
\text { lA3 subunit }\end{array}$ & $S$ & Periodic paralysis I & 170400 & $\begin{array}{l}\text { Chaudhari (1992); Ptacek et al. } \\
\text { (1994) }\end{array}$ \\
\hline DM15 & $\begin{array}{l}\text { Dystrophin myotonica } \\
\text { kinase, B15 }\end{array}$ & $\mathrm{K}, \mathrm{TE}$ & Dystrophia myotonica & 160900 & $\begin{array}{l}{ }^{\star} \text { Campbell (1995); }{ }^{\star} \text { Harper } \\
\text { (1995); Jansen et al. (1996); } \\
\text { Reddy et al. (1996) }\end{array}$ \\
\hline$D m a^{m d x}$ & $\begin{array}{l}\text { Dystrophia, muscular } \\
\text { dystrophy }\end{array}$ & $\mathrm{C}, \mathrm{S}$ & $\begin{array}{l}\text { Muscular dystrophy, Duchenne } \\
\text { and Becker types }\end{array}$ & 310200 & $\begin{array}{l}\text { Cox et al. (1993a; }{ }^{\star} \text { Campbell } \\
(1995) ;{ }^{\star} \text { Worton and Brooke } \\
(1995) ;{ }^{\star} \text { Nawrotzki et al. } \\
(1996)\end{array}$ \\
\hline$F m r 1$ & $\begin{array}{l}\text { Fragile } \mathrm{X} \text { mental } \\
\quad \text { retardation syndrome } 1\end{array}$ & $\mathrm{~K}$ & Fragile X syndrome & 309550 & $\begin{array}{l}\text { Bakker et al. (1994); }{ }^{\star} \text { Oostra and } \\
\text { Willems (1995) }\end{array}$ \\
\hline Galc ${ }^{t w i}$ & Galactosylceramidase & S & Krabbe disease & 245200 & ${ }^{\star}$ Suzuki et al. (1995) \\
\hline GIra1 $1^{\text {spd }}$ & $\begin{array}{l}\text { Glycine receptor, alpha } 1 \\
\text { subunit }\end{array}$ & $S$ & Kok disease ${ }^{c}$ & 149400 & $\begin{array}{l}\text { Shiang et al. (1993); Ryan et al. } \\
\text { (1994) }\end{array}$ \\
\hline$H d h$ & $\begin{array}{l}\text { Huntington disease gene } \\
\text { homolog }\end{array}$ & $\mathrm{K}$ & Huntington disease & 143100 & $\begin{array}{l}\text { Duyao et al. (1995); Nasir et al. } \\
\text { (1995); Zeitlin et al. (1995) }\end{array}$ \\
\hline $\operatorname{Lama} 2^{d y}$ & Laminin, alpha 2 & $S$ & Congenital muscular dystrophy & 156225 & $\begin{array}{l}\text { Sunada et al. (1994); Xu et al. } \\
\text { (1994); Helbling-Leclerc et al. } \\
\text { (1995) }\end{array}$ \\
\hline Mjd1 & Machado-Joseph disease & $\mathrm{TE}$ & Machado-Joseph disease & 109150 & $\begin{array}{l}\text { Kawaguchi et al. (1994); Ikeda et } \\
\text { al. (1996) }\end{array}$ \\
\hline$M p z$ & Myelin protein zero & $\mathrm{K}$ & $\begin{array}{l}\text { Charcot-Marie Tooth } \\
\text { neuropathy, type } 1 \mathrm{~B} \\
\text { Dejerine-Sottas syndrome }\end{array}$ & $\begin{array}{l}118200 \\
145900\end{array}$ & $\begin{array}{l}\text { Martini et al. (1995); *Suter and } \\
\text { Snipes (1995) }\end{array}$ \\
\hline$N f h$ & $\begin{array}{l}\text { Neurofilament, heavy } \\
\text { polypeptide }\end{array}$ & TE & Amyotrophic lateral sclerosis & 162230 & $\begin{array}{l}\text { *Brady (1993); Figlewicz et al. } \\
\text { (1994); }{ }^{*} \text { Brown (1995) }\end{array}$ \\
\hline Pbgd & $\begin{array}{l}\text { Porphobilinogen } \\
\text { deaminase }\end{array}$ & $\mathrm{K}$ & Acute intermittent porphyria & 176000 & $\begin{array}{l}\text { ^Kappas et al. (1995); Lindberg et } \\
\text { al. (1996) }\end{array}$ \\
\hline Phk & $\begin{array}{l}\text { Phosphorylase kinase, } \\
\text { alpha subunit }\end{array}$ & $S$ & Muscle glycogenosis, $\mathrm{X}$-linked & 311870 & $\begin{array}{l}\text { Schneider et al. (1993); Wehner } \\
\text { et al. (1994) }\end{array}$ \\
\hline$P l p^{i P}$ & Proteolipid protein & $\mathrm{K}, \mathrm{TE}, \mathrm{S}$ & $\begin{array}{l}\text { Pelizaeus-Merzbacher disease; } \\
\text { spastic paraplegia type } 2\end{array}$ & $\begin{array}{l}312080 \\
312920\end{array}$ & ${ }^{*}$ Griffiths et al. (1995) \\
\hline Pmp22 $2^{T r}$ & $\begin{array}{l}\text { Peripheral myelin } \\
\text { protein, } 22 \mathrm{kDa}\end{array}$ & $\mathrm{K}, \mathrm{S}$ & $\begin{array}{l}\text { Charcot-Marie Tooth } \\
\text { neuropathy type } 1 \mathrm{~A} ; \\
\text { hereditary neuropathy with } \\
\text { liability to pressure palsie }\end{array}$ & $\begin{array}{l}118220 \\
162550\end{array}$ & $\begin{array}{l}\text { Adlkofer et al. (1995); }{ }^{\star} \text { Suter and } \\
\text { Snipes (1995) }\end{array}$ \\
\hline Prn-p & Prion protein & $\mathrm{K}, \mathrm{TE}$ & $\begin{array}{l}\text { Familial fatal insomnia; } \\
\text { Creutzfeldt-Jacob and } \\
\text { Gerstmann-Straussler disease }\end{array}$ & 176640 & ${ }^{\star}$ Prusiner (1996) \\
\hline Ryr1 & $\begin{array}{l}\text { Ryanodine receptor } 1 \\
\text { skeletal muscle }\end{array}$ & $\mathrm{K}$ & Hyperthermia of anesthesia & 145600 & $\begin{array}{l}\text { MacLennan and Phillips (1992); } \\
\text { Takeshima et al. (1994) }\end{array}$ \\
\hline Sca1 & Spinocerebellar ataxia 1 & $\mathrm{TE}$ & Spinocerebellar ataxia type 1 & 164400 & $\begin{array}{l}\text { Burright et al. (1995); }{ }^{\star} \text { Zoghbi } \\
\text { and Orr (1995) }\end{array}$ \\
\hline Sod1 & $\begin{array}{l}\text { Superoxide dismutase-1, } \\
\text { soluble }\end{array}$ & $\mathrm{K}, \mathrm{TE}$ & Amyotrophic lateral sclerosis & 105400 & $\begin{array}{l}\text { *Brown (1995); Collard et al. } \\
\text { (1995); Wong et al. (1995); } \\
\text { Reaume et al. (1996); Tu et al. } \\
\text { (1996) }\end{array}$ \\
\hline
\end{tabular}

${ }^{a}$ See Table 1 for footnote.

${ }^{\mathrm{b}}$ Also associated with hyperlipoproteinemia (Table 7).

${ }^{\mathrm{c} A l s o}$ called hyperekplexia. 
may be the consequence, rather than the cause, of neurodegeneration. Others have documented age-dependent alterations in the brains of $A P P$-transgenic mice (Higgins and Cordell 1995; Hsiao et al. 1995; Moran et al. 1995). Significantly, Moran et al. (1995) have shown that these transgenic mice display learning deficits and Hsiao et al. (1995) have demonstrated that genetic background has a dramatic effect on the phenotype. All of these models will be very useful for understanding the role of APP in $A D$, for testing models that may either reduce $A \beta$ production or its toxicity, and for identifying modifiers that then may be used to develop effective therapies for $\mathrm{AD}$.

The normal function of App is not known; however, recent studies in mice indicate that it may be required for neuronal function. Mice homozygous for a "leaky" App mutation show defects in spatial learning and an increased incidence of agenesis of the corpus callosum (Müller et al. 1994). In addition, mice homozygous for a null App mutation, while not exhibiting any abnormalities in the corpus callosum (Zheng et al. 1995), showed decreased locomotor activity and reactive gliosis in the brain indicative of impaired neuronal function. These App-deficient mice will be useful to assess the effects of mutant App transgenes in the absence of possible interference by wild-type App encoded by the endogenous gene.

Mouse models may also prove useful for elucidating the role of APOE in AD. Although mice homozygous for null mutations in Apoe were reported originally to be neurologically normal (Popko et al. 1993), more recent studies have identified synaptic alterations and neurodegeneration in the CNS of Apoe null mice (Masliah et al. 1995). It will be very interesting to determine whether the neurological defects are exacerbated or alleviated in Apoe mutant mice that express mutant App transgenes. Transgenic mice that express the different human APOE isoforms individually have been generated already (Bowman et al. 1995) and should provide an excellent background in which to test interactions between the different APOE isoforms and mutant App peptides.

\section{Neurodegenerative disorders: Prion diseases}

The only diseases known to occur as sporadic, genetic, and transmissible forms are caused by nonviral infectious particles, called prions, whose sole component is prion protein (PrP; see Prusiner 1996). Either prion infection or mutation of the PrP gene causes neurodegeneration in sheep and cattle [scrapie and bovine spongiform encephalopathy (BSE), respectively], and in humans [kuru, Creutzfeldt-Jakob disease (CJD), GerstmannStraussler-Schinkler disease (GSS), and fatal familial insomnia (FFI) (MIM 176640)]. In humans, prion diseases cause progressive decline in cognitive and motor functions and pathological features in the CNS include spongiform degeneration, gliosis, neuronal loss, and amyloid plaques. Recently much attention has focused on these diseases as an epidemic of BSE occurred in Britain and other European countries, and the risk of transmission of the disease to humans via ingestion of contaminated beef is not known conclusively. Studies with mouse models have been instrumental not only for beginning to understand the pathogenesis of prion disease but also for quelling some of the concerns about possible interspecies transmission (see Collinge et al. 1995; Hope 1995).

The development of neuropathological alterations and transmissibility of disease in transgenic mice that express wild-type and mutant forms of PrP has provided conclusive evidence that this protein causes prion diseases (see Prusiner 1996). Although the initial analysis of mice homozygous for null Prn-p mutations did not reveal any significant developmental, behavioral, or neurological abnormalities, the mutant mice were resistant to prion infection and were unable to generate infectious particles. Subsequently, Collinge et al. (1994) reported that Prn-p-deficient mice have abnormalities in synaptic inhibition in the hippocampus. In contradiction, others reported no abnormalities in hippocampal electrophysiology in Prn-p-deficient mice and suggested that differences in genetic background may explain these discrepancies (Lledo et al. 1996). Further support for a role for $\mathrm{PrP}$ in the nervous system has been provided by two recent reports of Prn-p-deficient mice: Homozygous mutants display abnormalities of circadian activity rhythm and sleep (Tobler et al. 1996) and aged homozygous mice exhibit ataxia, impaired motor coordination, and extensive loss of Purkinje cells (Sakaguchi et al. 1996). The former phenotype is similar to that of FFI patients and suggests that this disease may result from loss-of-function (LOF) in PrP. Clearly, further studies on the mutant mice will be needed to clarify the role of $\operatorname{PrP}$ and its derivatives in neural function.

Two problems associated with a transgenic model of human GSS, in which the mice express Prn-p with a point mutation identical to a human mutant, are the wide variability in age of onset of the disease and the lack of amyloid plaques. Telling et al. (1996) have overcome these problems by crossing the transgene into the Prn-p null background, and the new model faithfully recapitulates virtually all features of human GSS. In addition, they clearly demonstrate that the wild-type Prn-p gene has a suppressive effect on the phenotype. Furthermore, mice that express human/mouse chimeric Prn- $p$ transgenes in a wild-type Prn-p background are resistant to infection by human prions, whereas susceptibility occurred when the transgene was expressed in a Prn- $p$ null background (Telling et al. 1995). To explain these observations, Prusiner and colleagues have proposed that prion formation requires the action of another host protein, perhaps analogous to a molecular chaperone (Telling et al. 1995, 1996). Identification of this protein and the mechanism by which it affects prion susceptibility could have important implications for prion, as well as other, diseases.

\section{Neuromuscular disorders}

The neuromuscular abnormalities described in Table 4 result from failure of the excitation-contraction coupling of skeletal muscle (Ryr1 and Cchl1a3 mutants), 
defects in muscle metabolism (Phk mutants), and degeneration and/or weakness of muscle $(D m d, D m 15$, and Lama 2 mutants). Here we will discuss recent results on mouse models of the latter type of disorders. Each of the corresponding human disorders has been reviewed recently (Campbell 1995; Nawrotzki et al. 1996).

Two X-linked traits in humans, Duchenne and Becker muscular dystrophies (DMD and BMD; MIM 310200), are attributable to mutations in dystrophin, a large cytoskeletal protein that localizes to the sarcolemma of normal skeletal muscle (Worton and Brooke 1995). DMD is the first major human disease gene to be discovered through positional cloning. Comparative mapping and phenotyjic similarities had suggested that the mouse homolog of DMD might be the $X$-linked muscular dystrophy $(m d x)$ locus, and Sicinski et al. (1989) reported a point mutation in the Dmd gene of these mice. Several other alleles of $m d x$ have been generated by chemical mutagenesis (Chapman et al. 1989) and one of these has been characterized at the molecular level (Cox et al. 1993b). In both DMD patients and $m d x$ mice, extensive necrosis of skeletal muscle fibers occurs. In DMD patients, significant muscle impairment occurs owing to the replacement of muscle tissue with fibrotic tissue and adipocytes. However, in $m d x$ mice, a high rate of muscle regeneration occurs and allows the mice to be relatively asymptomatic until -1 year of age. The one exception to this is the diaphragm, which displays severe myopathy. Nonetheless, these mice serve as important models for DMD and BMD and several laboratories have used them to test various models for gene therapy /Cox et al. 1993a; Vincent et al. 1993; Wells et al. 1995; Deconinck et al. 1996). Recently, a mouse model that more closely resembles the muscle pathology of DMD patients was generated (Megeney et al. 1996). In this model, mice that contain mutations in both $m d x$ and Myod, which encodes a myogenic transcription factor, were generated and the double mutants exhibit a much more pronounced myopathy resulting from lack of muscle regeneration.

Recent studies with $m d x$ mice have been used to test the hypothesis that the secondary loss of dystrophin associated proteins (DAPs) contributes to muscle degeneration. DAPs form a complex with dystrophin and together are thought to play a structural role in skeletal muscle (for review, see Campbell 1995). In both humans and mice, DAPs are reduced as the result of dystrophin deficiency. To determine directly whether DAP loss plays a role in muscle disease, two groups have introduced transgenes that express a truncated version of Dmd into $m d x$ mice (Cox et al. 1994; Greenberg et al. 1994). The truncated Dmd protein (Dp71) was able to localize to the membrane and restored normal levels of DAP. Significantly, however, the up-regulation of DAPs did not prevent myofiber degeneration in the $m d x$ mice, suggesting that other mechanisms must operate to cause the muscular degeneration.

The most frequent autosomal muscular dystrophy in humans is dystrophia myotonica (DM; MIM 160900), which is characterized by neuromuscular disturbances that affect skeletal muscle, smooth muscle of various organs, and a host of extramuscular features (Harper 1995). After nearly a decade of mapping and positional cloning, three laboratories reported in 1992 that the DM gene encodes a protein kinase, called DM15 (see Harper 1995). The causative mutation in DM15 is the instability of trinucleotide repeats in the $3^{\prime}$ untranslated region of the gene. Two groups recently have created targeted mutations in the Dm15 gene of mice (Jansen et al. 1996; Reddy et al. 1996). Both groups reported that the absence of Dm 15 causes progressive skeletal myopathy, but the two reports differ with respect to the severity of the alterations. Because both alleles are thought to be null mutations, and the mice are of similar genetic backgrounds, the reasons for these phenotypic differences are not known. In addition, Jansen et al. (1996) generated transgenic mice that overexpress normal human DMPK from a 14-kb genomic fragment. The expression pattern of this transgene faithfully reproduced that of the endogenous gene; however, myopathy of cardiac muscle was observed with the highest level of transgene expression and no abnormalities of skeletal muscle were noted. Although these mouse models do not clarify whether the DM15 alterations cause GOF or LOF mutations in humans, they will be useful for understanding the biological role of this gene product.

\section{Cancer}

The creation of inbred strains of mice, which began in the early part of this century, was in large part an attempt to develop better models for cancer research. Early experiments with these inbred strains of mice demonstrate clearly that cancer susceptibility behaved as a Mendelian trait and could be influenced by genetic background. The subsequent discovery of familial clustering of cancer susceptibility in humans suggested that cancer susceptibility could also be inherited as a Mendelian trait in humans (for review, see Knudson 1988). These "cancer family" syndromes show a dominant mode of inheritance with affected individuals usually developing a relatively broad but defined spectrum of cancers. We now know that many of these inherited cancer predisposition syndromes result from germ-line mutations in tumor suppressor genes (for review, see Hooper 1994). Most of the mouse models for these human cancer syndromes have been created by making knockout or transgenic mice (Table 5). These models have many advantages compared with human primary tumors or tumor cell lines because it is possible to study the effect of mutations on a uniform genetic background and in the absence of any other contributing somatic mutations. All of the mouse mutants described in Table 5, except for the knockouts of Brca1, Rb1, and Wt1, have phenotypes that closely parallel those of the corresponding human disease genes.

\section{Li-Fraumeni syndrome}

One well-studied cancer family syndrome is Li-Frau- 
Table 5. Neoplastic diseases

\begin{tabular}{|c|c|c|c|c|c|}
\hline $\begin{array}{l}\text { Mouse } \\
\text { gene } \\
\text { symbol }\end{array}$ & Gene name & $\begin{array}{l}\text { Mouse } \\
\text { model }^{\text {a }}\end{array}$ & Human disease & MIM no. & Selected references ${ }^{a}$ \\
\hline$A p c^{\operatorname{Min}}$ & $\begin{array}{l}\text { Adenomatous } \\
\text { polyposis cell }\end{array}$ & $\mathrm{C}, \mathrm{K}$ & $\begin{array}{l}\text { Adenomatous polyposis } \\
\text { of the colon }\end{array}$ & 175100 & $\begin{array}{l}\text { Groden et al. }(1991) ;{ }^{\star} \text { Moser et al. } \\
(1995) ;{ }^{\star} \text { Peifer (1996) }\end{array}$ \\
\hline Brca1 & Breast cancer 1 & $\mathrm{~K}$ & Breast cancer type 1 & 114480 & $\begin{array}{l}\text { *Cannon-Albright and Skolnick } \\
\text { (1996); Gowen et al. (1996); Hakem } \\
\text { et al. (1996) }\end{array}$ \\
\hline$C d k n 2 a$ & $\begin{array}{l}\text { Cyclin dependent } \\
\text { kinase inhibitor } \\
2 \mathrm{a}\end{array}$ & $\mathrm{K}$ & Malignant melanoma & 155600 & $\begin{array}{l}\text { Hussussian et al. (1994); Serrano et al. } \\
\quad(1996)\end{array}$ \\
\hline Mlh1 & $\begin{array}{l}\text { MutL (E. coli) } \\
\text { homolog } 1\end{array}$ & $\mathrm{~K}$ & $\begin{array}{r}\text { Familial colon cancer, } \\
\text { nonpolyposis type } 2\end{array}$ & 120436 & *Jass et al. (1994); Baker et al. (1996) \\
\hline Msh2 & $\begin{array}{l}\text { MutS }(E . \text { coli }) \\
\text { homolog } 2\end{array}$ & $\mathrm{~K}$ & $\begin{array}{r}\text { Familial colon cancer, } \\
\text { nonpolyposis type } 1\end{array}$ & 120435 & $\begin{array}{l}\text { *Jass et al. (1994); de Wind et al. } \\
\text { (1995); Reitmair et al. (1995) }\end{array}$ \\
\hline Pms2 & $\begin{array}{l}\text { Postmeiotic } \\
\quad \text { segregation } \\
\text { increased } 2 \\
\text { (S. cerevisiae) }\end{array}$ & $\mathrm{K}$ & $\begin{array}{r}\text { Familial colon cancer, } \\
\text { nonpolyposis type } 3\end{array}$ & 600259 & $\begin{array}{l}\text { *Jass et al. (1994); Nicolaides et al. } \\
\text { (1994); Baker et al. (1995) }\end{array}$ \\
\hline$N f 1$ & $\begin{array}{l}\text { Neurofibromatosis } \\
\text { type } 1\end{array}$ & $\mathrm{~K}$ & Neurofibromatosis type 1 & 162200 & $\begin{array}{l}\text { *Gutmann and Collins (1993); } \\
\text { Brannan et al. (1994); Jacks et al. } \\
\text { (1994) }\end{array}$ \\
\hline$R b 1$ & Retinoblastoma-1 & $\mathrm{K}$ & Familial retinoblastoma & 180200 & ${ }^{\star}$ Hooper $(1994) ;{ }^{\star}$ Clarke $(1995)$ \\
\hline $\operatorname{Ret}^{\mathrm{b}}$ & $\begin{array}{l}\text { Receptor tyrosine } \\
\text { kinase }\end{array}$ & $\mathrm{TE}$ & $\begin{array}{l}\text { Multiple endocrine } \\
\text { neoplasia type } 2 \\
\text { familial medullary } \\
\text { thyroid carcinoma }\end{array}$ & $\begin{array}{l}171400 \\
155240\end{array}$ & $\begin{array}{l}{ }^{*} \text { Goodfellow (1994); Jhiang et al. } \\
\text { (1996); Santoro et al. (1996) }\end{array}$ \\
\hline $\operatorname{Trp53}$ & $\begin{array}{l}\text { Transformation- } \\
\text { related protein } \\
53\end{array}$ & $\mathrm{~K}, \mathrm{TE}$ & Li-Fraumeni syndrome & 151623 & $\begin{array}{l}{ }^{*} \text { Hooper (1994); * Malkin (1994); } \\
{ }^{\star} \text { Jacks (1996) }\end{array}$ \\
\hline$W t 1$ & $\begin{array}{l}\text { Wilms' tumor } \\
\text { homolog }\end{array}$ & $\mathrm{K}$ & $\begin{array}{l}\text { Wilm's tumor; } \\
\text { Denys-Drash } \\
\text { syndrome }\end{array}$ & $\begin{array}{l}194070 \\
194080\end{array}$ & $\begin{array}{l}\text { Kreidberg et al. (1993); }{ }^{*} \text { Mueller } \\
(1994) ;{ }^{\star} \text { Hastie }(1994)\end{array}$ \\
\hline
\end{tabular}

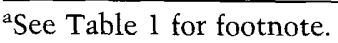

${ }^{\mathrm{b}}$ Also associated with Hirschprung's disease (Table 1),

meni syndrome (LFS; MIM 151623). LFS is a rare autosomal dominant disorder caused by germ-line mutations in the p53 (TRP53) tumor suppressor gene (for review, see Malkin 1994). LFS patients develop a variety of cancers, notably soft tissue sarcoma, breast carcinoma, brain tumors, osteosarcoma, leukemia, and adrenocortical carcinoma. Sporadic mutations in TRP53 also occur in approximately half of all primary human tumors making it one of the most commonly mutated human cancer genes (Nigro et al. 1989; Hollstein et al. 1991; for review, see Levine et al. 1991). The majority of tumors with TRP53 mutations contain a missense mutation in one allele and a loss of the second allele. When expressed as transgenes in mice, these mutant forms of TRP53 give rise to a variety of tumor types showing significant overlap with those often seen in LFS patients (Lavigueur et al. 1989). In addition, there is considerable evidence that many of these TRP53 missense mutant proteins possess dominant-negative activity compared to wild-type (Harvey et al. 1995). Like LFS patients, mice heterozygous for Trp53 null mutations develop tumors, but with a longer latent period than homozygous mutant animals (for review, see Hooper 1994; Malkin 1994; Clarke 1995; Jacks 1996).
Interestingly, the spectrum of tumor types in these strains is influenced strongly by strain background (for review, see Hooper 1994). Modifier genes affecting tumor incidence might thus be identifiable in these strains.

\section{Multiple endocrine neoplasia type 2}

Mutations in proto-oncogenes are also found in sporadic tumors, yet they are involved less frequently in hereditary human cancers. One exception is the RET protooncogene. Activating GOF mutations in the RET receptor tyrosine kinase have been found in multiple endocrine neoplasia type 2 (MEN2; MIM 171400) and familial medullary thyroid carcinoma (FMTC; MIM 155240) (Donis-Keller et al. 1993; Mulligan et al. 1993; for review, see Goodfellow 1994). MEN2 is a dominantly inherited cancer syndrome characterized by the development of medullary thyroid carcinoma and pheochromocytoma in the type $2 \mathrm{~A}$ form as well as ganglioneuromas of the gastrointestinal tract and skeletal and opthalmic abnormalities in the type 2B form. Transgenic mice expressing an activated form of RET under the control of a bovine or rat thyroglobulin gene promoter develop papillary thyroid 
carcinoma and are a promising model for $R E T$-induced malignancies (Jhiang et al. 1996; Santoro et al. 1996).

\section{Colorectal cancer}

In the last several years, it has become apparent that genetic predisposition to cancer can also result from mutations in DNA repair genes. For example, individuals heterozygous for mutations in the human MutS homolog 2 (MSH2) gene develop familial colon cancer, nonpolyposis type 1 (MIM 120435) and tumors show microsatellite length instability (Fishel et al. 1993; Leach et al. 1993). Mutations in other DNA repair genes, MutL homolog 1 (MLH1) and postmeiotic segregation increased 2 (PMS2), are responsible for familial colon cancer, nonpolyposis, types 2 (MIM 120436) and 3 (MIM 276300, 600259), respectively (Bronner et al. 1994; Hemminki et al. 1994; Nicolaides et al. 1994). Mice homozygous for an inactivating mutation in the Msh2 gene are fully viable and fertile. However, beginning at two months of age homozygous Msh2 mice develop a high frequency of lymphomas that show microsatellite instability (deWind et al. 1995; Reitmair et al. 1995). As a general regulator of DNA repair, it might be expected that a Msh2 mutation would uncover underlying tumor susceptibility in an organism. This may explain why Msh2-deficient mice, as well as Pms2 and likely Mlh1-deficient mice, develop lymphomas and sometimes sarcomas (Baker et al. 1995, 1996), whereas humans who have inherited mutations in these genes develop colorectal, endometrial, and gastric tumors.

The genetic predisposition to most human cancers is not associated with single-gene mutations but rather results from complex interactions involving mutations in many different genes. A good example of this in mice is provided by the recent identification of a candidate gene for a modifier of a mutation that causes intestinal adenoma formation (Dietrich et al. 1993; MacPhee et al. 1995). Multiple intestinal neoplasia (Min) mice develop intestinal adenomas and adenocarcinomas resulting from a missense mutation in the adenomatous polyposis coli $(A p C)$ gene (Su et al. 1992). Mutations in the human homolog of this tumor suppressor gene cause a very similar disease in humans (Groden et al. 1991). APC is a large protein associated with the plasma membrane that binds to $\beta$-catenin, an adherins junction protein, and regulates signaling through the Wnt/Wingless pathway (for review, see Peifer 1996). In Apc mice, the number of intestinal adenomas is strongly affected by a modifier of Min, called Mom1, that is carried by various inbred strains of mice (Deitrich et al. 1993). An excellent candidate for Mom1 was identified by MacPhee et al. (1995) as the secretory phospholipase A2 (Pla2s) gene. All strains sensitive to high incidence of adenomas express very low Pla2s mRNA levels and have a frameshift mutation in Pla2s (MacPhee et al. 1995). Although PLA2S mutations have not yet been identified in humans with intestinal neoplasms or in patients predisposed to these cancers, it remains possible that mutations in this or other genes in the PLA2S biochemical pathway may influence polyp formation in humans.

\section{Immunological and hematological disorders}

There are many well-known inherited human blood cell diseases such as the X-linked hemophilias and immunodeficiencies, and the anemias associated with defects in adult $\alpha$ - and $\beta$-globin genes. Many of these disorders have been modeled in mice (Table 6), and all of the models listed, with the exception of adenosine deaminase (Ada)-deficient mice, have many phenotypic similarities to their human counterparts. The mouse models for hematological and immunological diseases are being used to test new therapeutic approaches. As the hematopoietic system is a relatively accessible tissue from which stem cells can be isolated, much work has focused on gene therapy. In addition, new insights into the physiological significance of these gene products are being acquired.

\section{Sickle cell anemia}

Sickle cell anemia (MIM 141900) was one of the first diseases demonstrated to be a molecular disease when Linus Pauling and colleagues showed that an altered $\beta$-globin was inherited in a Mendelian fashion that cosegregated with the disorder (for review, see Weatherall et al. 1995). The creation of a mouse model for sickle cell anemia provides a good example of the level of sophistication with which the mouse germ line can be manipulated to create a mouse disease model. Most transgenic mice expressing a normal human $\alpha$-globin gene in addition to the sickle cell mutant human $\beta$-globin gene, $\beta^{\mathrm{S}(6 \mathrm{Val})}$, did not develop sickle cell anemia as hoped because the endogenous mouse major $\beta$-globin polypeptide interferes with the polymerization of the human $\alpha$ - and $\beta$-globins (for review, see Fabry 1993). This problem was partially overcome by introducing the $\alpha$-and $\beta$-globin transgenes into mice hemizygous for a chemically induced germ-line mutation in the major endogenous mouse $\beta$-globin gene. In addition to the classic human $\beta^{\mathrm{S}(6 \mathrm{~V} a \mathrm{l})}$ sickle cell mutation, other mutations that enhance the sickling phenotype also have been introduced into the human $\beta$-globin transgene together with the $\beta^{\mathrm{S}(6 \mathrm{Val})}$ mutation (Trudel et al. 1991, 1994; Fabry et al. 1995). The net result of these studies is that researchers now have a variety of sickle cell disease models in the mouse with phenotypes ranging from mild to severe, which respond to clinically utilized antisickling agents (Trudel et al. 1994), and which will be useful for testing new therapeutic approaches.

\section{Immune deficiencies}

Many models of human immune deficiency exist in the mouse and generally show good correlation with the human disease. These models also have allowed detailed studies of many of the proteins required for such processes as cellular adhesion (integrin $\beta 2, \operatorname{Itgb} 2$ ), $\mathrm{T} / \mathrm{B}$ cell 
Table 6. Immunological and hematological diseases

\begin{tabular}{|c|c|c|c|c|c|}
\hline $\begin{array}{l}\text { Mouse } \\
\text { gene } \\
\text { symbol }\end{array}$ & Gene name & $\begin{array}{l}\text { Mouse } \\
\text { model }^{\mathrm{a}}\end{array}$ & Human disease & MIM no. & Selected references ${ }^{\mathrm{a}}$ \\
\hline Ada & Adenosine deaminase & $\mathrm{K}$ & $\begin{array}{l}\text { Severe combined } \\
\text { immunodeficiency }\end{array}$ & 102700 & $\begin{array}{l}\text { * Markert (1994); Migchielsen et al. } \\
\text { (1995) }\end{array}$ \\
\hline$A n k 1^{n b}$ & Ankyrin 1 , erythroid & $S^{b}$ & Hereditary spherocytosis & 182900 & $\begin{array}{l}\text { White et al. (1990); Peters et al. } \\
\text { (1991); Jarolim et al. (1995); Eber } \\
\text { et al. (1996) }\end{array}$ \\
\hline$B t k^{x i d}$ & Bruton's tyrosine kinase & $S$ & $\begin{array}{l}\text { X-linked } \\
\text { agammaglobulinemia }\end{array}$ & 300300 & ${ }^{\star}$ Rawlings and Witte (1994) \\
\hline Cd401 & CD40 ligand & $\mathrm{K}$ & $\begin{array}{l}\text { Hyper-IgM } \\
\text { immunodeficiency; } \\
\text { common variable } \\
\text { immunodeficiency }\end{array}$ & 308230 & $\begin{array}{l}\text { Renshaw et al. (1994); Farrington } \\
\text { et al. (1994); * Ramesh et al. } \\
\text { (1994) }\end{array}$ \\
\hline $\mathrm{C} / 8$ & Coagulation factor VIII & $\mathrm{K}$ & Hemophilia A & 306700 & $\begin{array}{l}\text { Bi et al. (1995); *Kazazian et al. } \\
\text { (1995) }\end{array}$ \\
\hline$C y b b$ & $\begin{array}{l}\text { Cytochrome b-245, beta } \\
\text { polypeptide }\end{array}$ & $\mathrm{K}$ & $\begin{array}{l}\text { Chronic granulomatous } \\
\text { disease }\end{array}$ & 306400 & $\begin{array}{l}\text { `Roos et al. (1994); Pollock et al. } \\
(1995)\end{array}$ \\
\hline $\operatorname{Epb4.2^{pa}}$ & $\begin{array}{l}\text { Erythrocyte protein band } \\
\quad 4.2\end{array}$ & $\mathrm{~S}$ & $\begin{array}{l}\text { Hereditary hemolytic } \\
\text { anemia }\end{array}$ & 177070 & $\begin{array}{l}\text { White et al. (1992); * Becker and } \\
\text { Lux (1995) }\end{array}$ \\
\hline Fas ${ }^{l p r}$ & Fas antigen $1^{\mathrm{c}}$ & $\mathrm{S}$ & $\begin{array}{l}\text { Autoimmune } \\
\text { lymphoproliferative } \\
\text { syndrome }\end{array}$ & 134637 & $\begin{array}{l}\text { * Singer et al. (1994); Fisher et al. } \\
\text { (1995); Rieux-Laucat et al. (1995) }\end{array}$ \\
\hline $\mathrm{Hba}$ & $\begin{array}{l}\text { Hemoglobin alpha gene } \\
\text { cluster }\end{array}$ & $\mathrm{C}, \mathrm{K}, \mathrm{R}$ & Alpha-thalassemia & 141800 & $\begin{array}{l}\text { Russell et al. (1976); Whitney et al. } \\
\text { (1980); Pászty et al. (1995); } \\
{ }^{\star} \text { Weatherall (1995) }\end{array}$ \\
\hline$H b b$ & $\begin{array}{l}\text { Hemoglobin beta gene } \\
\text { cluster }\end{array}$ & $\mathrm{C}, \mathrm{K}$ & Beta-thalassemia & $141900^{\mathrm{d}}$ & $\begin{array}{l}\text { Skow et al. (1983); Shehee et al. } \\
\text { (1993); Ciavatta et al. (1995); } \\
{ }^{\star} \text { Weatherall (1995) }\end{array}$ \\
\hline$H b b$ & $\begin{array}{l}\text { Hemoglobin beta gene } \\
\text { cluster }\end{array}$ & $\mathrm{C}+\mathrm{TE}$ & Sickle cell anemia & $141900^{\mathrm{d}}$ & $\begin{array}{l}\text { Trudel et al. (1991); Fabry et al. } \\
(1995)_{;}{ }^{\star} \text { Weatherall (1995) }\end{array}$ \\
\hline $\operatorname{Itg} b 2^{e}$ & Integrin beta 2 & $\mathrm{~K}$ & $\begin{array}{l}\text { Leukocyte adhesion } \\
\text { deficiency, Type } 1\end{array}$ & 116920 & $\begin{array}{l}\text { *Anderson and Springer (1987); } \\
\text { Wilson et al. (1993); Bullard et } \\
\text { al. (1996) }\end{array}$ \\
\hline$I 12 r g$ & $\begin{array}{l}\text { IL-2 receptor gamma } \\
\text { chain (gamma } \\
\text { common) }\end{array}$ & $\mathrm{K}$ & $\begin{array}{l}\text { Severe combined } \\
\text { immunodeficiency, } \\
\text { X-linked }\end{array}$ & 300400 & $\begin{array}{l}{ }^{\star} \text { Leonard et al. (1994); DiSanto et } \\
\text { al. }(1995)\end{array}$ \\
\hline Lyst $^{\text {bg }}$ & $\begin{array}{l}\text { Lysosomal trafficking } \\
\text { regulator }\end{array}$ & S & $\begin{array}{l}\text { Chediak-Higashi } \\
\text { syndrome }\end{array}$ & 214500 & $\begin{array}{l}\text { Barbosa et al. (1996); Perou et } \\
\text { al. (1992) }\end{array}$ \\
\hline $\operatorname{Rag} 1^{f}$ & $\begin{array}{l}\text { Recombination } \\
\text { activating gene-1 }\end{array}$ & $\mathrm{K}$ & $\begin{array}{l}\text { Severe combined } \\
\text { immunodeficiency, } \\
\text { B-cell negative }\end{array}$ & 601457 & $\begin{array}{l}\text { Mombaerts et al. (1992); Shinkai et } \\
\text { al. (1992); Schwartz et al. (1996) }\end{array}$ \\
\hline Spna $1^{\text {sph }}$ & $\begin{array}{l}\text { Alpha-spectrin-1, } \\
\text { erythroid }\end{array}$ & $\mathrm{TI}, \mathrm{S}$ & Elliptocytosis-2 & 130600 & $\begin{array}{l}\text { Grimber et al. (1992); }{ }^{\star} \text { Gallagher } \\
\text { and Forget (1993) }\end{array}$ \\
\hline Spnb1 $1^{\text {ja }}$ & Beta-spectrin-1 & $S$ & Elliptocytosis-3 & 182870 & $\begin{array}{l}\text { *Gallagher and Forget (1993); } \\
\text { Bloom et al. (1994) }\end{array}$ \\
\hline
\end{tabular}

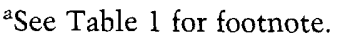

${ }^{\mathrm{b}}$ Although a mutation in the Ank1 gene of $n b$ mice has not been identified, $n b / n b$ mice express lower levels of ankyrin mRNA and protein and express a truncated ankyrin protein (White et al. 1990; Peters et al. 1991).

${ }^{\mathrm{c} A l s o}$ called Apoptosis antigen-1 (APT-1), APO-1, and CD95.

${ }^{\mathrm{d}}$ All hemoglobin beta locus $(H B B)$ mutations and phenotypic data can be accessed at MIM no. 141900.

${ }^{\mathfrak{e}}$ Also called CD18 antigen, macrophage antigen-1 beta, and LFA-1.

${ }^{\mathrm{f}}$ Both the RAG1 and RAG2 genes, which are closely linked in both mouse and human, have been shown to be mutated in some patients with B cell-negative SCID. Inactivation of these genes in mice gives a very similar phenotype (Mombaerts et al. 1992; Shinkai et al. 1992).

communication (CD40 ligand, Cd401), and signal transduction by tyrosine kinases (Bruton's tyrosine kinase, Btk). In several cases, the identification of a mutant gene product in a human disease was followed by the creation of knockout mutations in the mouse.
The recent identification of the gene affected in Chediak-Higashi syndrome (CHS; MIM 214500) was preceded by and depended on the cloning of the mouse beige (bg) gene (Barbosa et al. 1996; Perou et al. 1996). It had been suggested that $b g$ mice and CHS patients may have 
mutations in homologous genes based on comparative mapping, somatic cell complementation analysis, and phenotypic similarities (Justice et al. 1990; Perou and Kaplan 1993; Barrat et al. 1996). Cells from both CHS patients and $b g$ mice show lysosomal defects and compartmental missorting that are thought to arise from defective homotypic vesicle fusion (Perou and Kaplan 1993). These problems are manifested as a dilution of pigmentation, abnormal bleeding, natural killer cell dysfunction, and an increased susceptibility to infection. The $b g$ gene was shown to be lysosomal trafficking regulator (Lyst) and is predicted to encode a large protein with a carboxyl-terminal prenylation motif, multiple phosphorylation sites, and an extended coil-coiled domain (Barbosa et al. 1996; Perou et al. 1996). Subsequently, the same gene was shown to be mutated in CHS patients. The cloning of Lyst has revealed a novel, apparently critical component of lysosome function that is required for normal function of a number of hematopoietic cells and melanocytes in both species.

\section{Autoimmune lymphoproliferative syndrome}

Many very important human diseases, such as diabetes, arthritis, lupus, and glomerulonephritis, have an autoimmune component. Studies on two mouse mutations, lymphoproliferation (lpr) and generalized lymphadenopathy $(g l d)$, have demonstrated the important role of apoptosis in the maintenance of immune self-tolerance. In addition, the cloning of the Ipr gene has led to the identification of human patients with mutations in the same gene who suffer from a strikingly similar autoimmune disease. Mice homozygous for the lpr or the gld mutation have identical phenotypes and display massive lymphoid enlargement because of $T$ cell accumulation. This is accompanied by autoimmune vasculitis and immune complex glomerulonephritis (for review, see Singer et al. 1994). Using a candidate gene approach, mutations in the gene encoding Fas antigen [also called apoptosis antigen (Apt) or CD95] were shown to cause the Ipr phenotype (Watanabe-Fukunaga et al. 1992). The Fas gene encodes a member of the tumor necrosis factor (TNF) receptor family, and its ligand, called Fasl, is a member of the TNFrelated type II family and was subsequently shown to be mutated in gld mice (Takahashi et al. 1994b). Patients with autoimmune lymphoproliferative syndrome (ALPS; MIM 134637) have been shown to have mutations in the FAS gene, and many of these mutant products appear to behave as dominant negative proteins (Fisher et al. 1995; Rieux-Laucat et al. 1995).

There is strong evidence that many mouse and human autoimmune diseases are influenced by modifying genes and the $1 p r /$ ALPS diseases are not exceptions. In some affected ALPS families, individuals with FAS mutations have no clinical symptoms (Fisher et al. 1995), whereas the $1 p r$ mutation causes no autoimmune disease in C57BL/6 mice and only mild disease in $\mathrm{C} 3 \mathrm{H}$ mice. The identification of genetic modifiers of the $1 p r$ phenotype may shed light on human predisposition to autoimmune disease.

\section{Metabolic and hormonal disorders}

In Table 7 mouse models of metabolic and hormonal disease caused by mutations in 24 different genes are described. Although the majority of these models reproduce many of the phenotypes associated with mutations in the corresponding human homolog, the current mutants for hexokinase A (HexA), hypoxanthine guanine phosphoribosyl transferase (Hprt), and urate oxidase (UOX) in the mouse do not. These three mouse mutants thus illustrate that mice and humans, although very similar in most metabolic pathways, do have some significant differences.

\section{Disorders of purine metabolism}

Purine nucleotides are recycled from purine bases by the action of two phosphoribosyltransferases; adenine phosphoribosyl transferase (APRT) catalyzes the conversion of adenosine monophosphate (AMP) from adenine, and hypoxanthine guanine phosphoribosyl transferase (HPRT) catalyzes the conversion of inosine monophosphate (IMP) or guanosine monophosphate (GMP) from hypoxanthine or guanine, respectively (see Fig. 5). In the absence of APRT, adenine is converted to 2,8 dihydroxyadenine and the accumulation of this insoluble product causes the development of kidney stones that may progress to kidney failure (for review, see Simmonds et al. 1995; MIM 102600). Recently, a targeted null mutation in Aprt was generated in mice that causes a phenotype identical to that of humans (Engle et al. 1996a) and thus will be a very useful model for understanding how kidney stones develop and contribute to renal disease. As the severity of the Aprt mutant phenotype is different in two different genetic backgrounds, Engle et al. (1996a) have suggested that other factors, affecting either adenine metabolism, stone formation, or kidney function, may be the basis for these phenotypic differences. Further analysis of these possible modifiers should be useful for understanding phenotypic variation seen in APRT deficient humans.

HPRT deficiency in humans causes Lesch-Nyhan syndrome (MIM 308000), an X-linked recessive disease characterized by hyperuricemia, mental retardation, and compulsive self-mutilation (for review, see Rossiter and Caskey 1995). Several groups have attempted to generate a mouse model for Lesch-Nyhan by constructing targeted mutations in the Hprt gene (Williamson et al. 1992). Although these were the first successful reports of germ-line transmission of targeted mutations in the mouse, the Hprt mutant mice did not exhibit any significant abnormalities. Two possible explanations for these interspecific differences have been proposed. The first possibility is that Aprt may be more important than Hprt for purine recycling in mice compared with humans. Wu and Melton (1993) have tested this by administering an inhibitor of Aprt to Hprt mice and found that these mice developed self-inflicted injuries that resulted from overgrooming. Thus, alteration of the metabolic pathways of mutant mice improved the usefulness of 
Table 7. Metabolic and hormonal diseases

\begin{tabular}{|c|c|c|c|c|c|}
\hline $\begin{array}{l}\text { Mouse } \\
\text { gene } \\
\text { symbol }\end{array}$ & Gene name & $\begin{array}{l}\text { Mouse } \\
\text { model }^{\text {a }}\end{array}$ & Human disease & MIM no. & Selected references ${ }^{\mathbf{a}}$ \\
\hline$A p o b$ & Apolipoprotein B & $\mathrm{K}, \mathrm{TE}$ & Hypobetalipoproteinemia & 107730 & $\begin{array}{l}\text { *Young et al. (1994); Farese et al. } \\
\text { (1995); Huang et al. (1995); *Knecht } \\
\text { and Glass (1995) }\end{array}$ \\
\hline$A p o e^{b}$ & Apolipoprotein E & $\mathrm{K}, \mathrm{TE}$ & $\begin{array}{l}\text { Hyperlipoproteinemia } \\
\text { type III }\end{array}$ & 107741 & $\begin{array}{l}{ }^{\star} \text { Knecht and Glass (1995); }{ }^{\star} \text { Plumb } \\
\text { and Breslow (1995); }{ }^{\star} \text { Breslow (1996) }\end{array}$ \\
\hline Aprt & $\begin{array}{l}\text { Adenine phosphoribosyl } \\
\text { transferase }\end{array}$ & $\mathrm{K}$ & $\begin{array}{l}\text { 2,8-Dihydroxyadenine } \\
\text { urolithiasis }\end{array}$ & 102600 & $\begin{array}{l}{ }^{*} \text { Simmonds et al. (1995); Engle et al. } \\
(1996)\end{array}$ \\
\hline$A r^{T f m}$ & Androgen receptor & $\mathrm{S}, \mathrm{TE}$ & $\begin{array}{l}\text { Testicular feminization } \\
\text { syndrome, spinal and } \\
\text { bulbar muscular } \\
\text { atrophy }\end{array}$ & $\begin{array}{l}313700 \\
313200\end{array}$ & $\begin{array}{l}\text { Gaspar et al. (1991); La Spada et al. } \\
\text { (1991); Bingham et al. (1995) }\end{array}$ \\
\hline Atp $7 a^{M o}$ & $\begin{array}{l}\text { ATPase, } \mathrm{Cu++} \\
\text { transporting, alpha } \\
\text { polypeptide }\end{array}$ & $\mathrm{C}, \mathrm{R}, \mathrm{S}$ & $\begin{array}{l}\text { Menkes syndrome; } \\
\text { occipital horn } \\
\text { syndrome }\end{array}$ & $\begin{array}{l}304150 \\
309400\end{array}$ & $\begin{array}{l}\text { Levinson et al. (1994); Mercer et al. } \\
\text { (1994); Das et al. (1995); * Monaco } \\
\text { and Chelly (1995) }\end{array}$ \\
\hline Casr & Calcium-sensing receptor & $\mathrm{K}$ & $\begin{array}{l}\text { Familial hypocalciuric } \\
\text { hypercalcemia; } \\
\text { neonatal severe } \\
\text { hyperparathyroidism }\end{array}$ & $\begin{array}{l}145980 \\
239200\end{array}$ & Pollack et al. (1993); Ho et al. (1995) \\
\hline Cftr & $\begin{array}{l}\text { Cystic fibrosis } \\
\text { transmembrane } \\
\text { conductance regulator } \\
\text { homolog }\end{array}$ & $\mathrm{K}$ & Cystic fibrosis & 219700 & $\begin{array}{l}\text { *Drumm and Collins (1993); *Dorin } \\
(1995)\end{array}$ \\
\hline Fah & $\begin{array}{l}\text { Fumarylacetoacetate } \\
\text { hydrolase }\end{array}$ & $\mathrm{K}, \mathrm{R}$ & Tyrosinemia, type I & 276700 & $\begin{array}{l}\text { Klebig et al. (1992); Grompe et al. } \\
(1993) ;{ }^{\star} \text { Mitchell et al. }\{1995)\end{array}$ \\
\hline Fech $^{\text {mlPas }}$ & Ferrochelatase & $\mathrm{C}$ & $\begin{array}{l}\text { Erythropoietic } \\
\text { protoporphyria }\end{array}$ & 177000 & $\begin{array}{l}\text { Boulechfar et al. (1993); }{ }^{*} \text { Kappas et al. } \\
\text { (1995) }\end{array}$ \\
\hline G6pt & Glucose-6-phosphatase & $\mathrm{K}$ & $\begin{array}{l}\text { Glycogen storage } \\
\text { disease-I }\end{array}$ & 232200 & $\begin{array}{l}\text { Chen and Burchell (1995); Lei et al. } \\
\text { (1996) }\end{array}$ \\
\hline Gba & Glucocerebrosidase & $\mathrm{K}$ & Gaucher disease type I & 230800 & $\begin{array}{l}\text { Tybulewicz et al. (1992); Bornstein et } \\
\text { al. (1995) }\end{array}$ \\
\hline$G h r h r^{\text {lit }}$ & $\begin{array}{l}\text { Growth hormone } \\
\text { releasing hormone } \\
\text { receptor }\end{array}$ & $\mathrm{S}$ & $\begin{array}{l}\text { Growth hormone } \\
\text { deficiency }\end{array}$ & 139191 & $\begin{array}{l}\text { Godfrey et al. (1993); Lin et al. (1993); } \\
\text { Wainrajch et al. (1996) }\end{array}$ \\
\hline Gus $s^{m p s}$ & Beta-glucuronidase & $\mathrm{S}$ & $\begin{array}{l}\text { Mucopolysaccharidosis } \\
\text { type VII }\end{array}$ & 253220 & $\begin{array}{l}\text { Sands and Birkenmeier (1993); Berry } \\
\text { et al. (1994); }{ }^{\star} \text { Neufeld and Muenzer } \\
\text { (1995) }\end{array}$ \\
\hline Hexa & Hexokinase A & $\mathrm{K}$ & Tay-Sachs disease & 272800 & $\begin{array}{l}\text { Yamanaka et al. (1994); Sango et al. } \\
\mid 1995\}\end{array}$ \\
\hline$H e x b$ & Hexokinase B & $\mathrm{K}$ & Sandhoff disease & 268800 & Sango et al. $(1995)$ \\
\hline Hprt & $\begin{array}{l}\text { Hypoxanthine guanine } \\
\text { phosphoribosyl } \\
\text { transferase }\end{array}$ & $\mathrm{K}$ & Lesch-Nyhan syndrome & 308000 & $\begin{array}{l}{ }^{\star} \text { Williamson et al. (1992); * Rossiter } \\
\text { and Caskey (1995) }\end{array}$ \\
\hline$L d l r$ & $\begin{array}{l}\text { Low density lipoprotein } \\
\text { receptor }\end{array}$ & $\mathrm{K}, \mathrm{TE}$ & $\begin{array}{l}\text { Familial } \\
\text { hypercholesterolemia }\end{array}$ & 143890 & $\begin{array}{c}{ }^{*} \text { Breslow }(1994,1996) ;{ }^{\star} \text { Paigen et al. } \\
(1994) ;{ }^{\star} \text { Knecht and Glass (1995) }\end{array}$ \\
\hline Otc ${ }^{s p f}$ & $\begin{array}{l}\text { Ornithine } \\
\text { transcarbamylase }\end{array}$ & $\mathrm{S}$ & Hyperammonemia & 311250 & $\begin{array}{l}\text { Veres et al. (1987); }{ }^{\star} \text { Brusilow and } \\
\text { Horwich (1995) }\end{array}$ \\
\hline Pah & $\begin{array}{l}\text { Phenylalanine } \\
\text { hydroxylase }\end{array}$ & $\mathrm{C}$ & Phenylketonuria & 261600 & $\begin{array}{l}\text { Shedlovsky et al. (1993); }{ }^{\star} \text { Scriver et } \\
\text { al. (1995) }\end{array}$ \\
\hline Ppgb & $\begin{array}{l}\text { Protective protein for } \\
\text { beta-galactosidase }\end{array}$ & $\mathrm{K}$ & Galactosialidosis & 256540 & $\begin{array}{l}\text { *d'Azzo et al. (1995); Zhou et al. } \\
(1995)\end{array}$ \\
\hline Pit $1^{d w}$ & $\begin{array}{l}\text { Pituitary specific } \\
\text { transcription factor-1 }\end{array}$ & $\mathrm{S}$ & $\begin{array}{l}\text { Combined pituitary } \\
\text { hormone deficiency }\end{array}$ & 173110 & $\begin{array}{l}\text { *Voss and Rosenfeld (1992); Radovick } \\
\text { et al. (1992) }\end{array}$ \\
\hline Smpd1 & $\begin{array}{l}\text { Sphingomyelin } \\
\text { phosphodiesterase } 1\end{array}$ & $\mathrm{~K}$ & Niemann-Pick disease & 257200 & $\begin{array}{l}\text { Horinouchi et al. }(1995) ; \text { Otterbach } \\
\text { and Stoffel (1995) }\end{array}$ \\
\hline Tshrhyt & $\begin{array}{l}\text { Thyroid stimulating } \\
\text { hormone receptor }\end{array}$ & $S$ & $\begin{array}{l}\text { Unresponsiveness to } \\
\text { thyrotropin }\end{array}$ & 275200 & $\begin{array}{l}\text { Duprez et al. (1994); Stein et al. } \\
\text { (1994) }\end{array}$ \\
\hline Uox & Urate oxidase & $\mathrm{K}$ & Hyperuricemia and gout & 191540 & $\begin{array}{l}\text { Wu et al. 1994; }{ }^{\star} \text { Becker and Roessler } \\
\text { (1995) }\end{array}$ \\
\hline
\end{tabular}

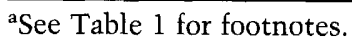

${ }^{\mathrm{b}}$ Also associated with Alzheimer disease-2 (Table 4) 


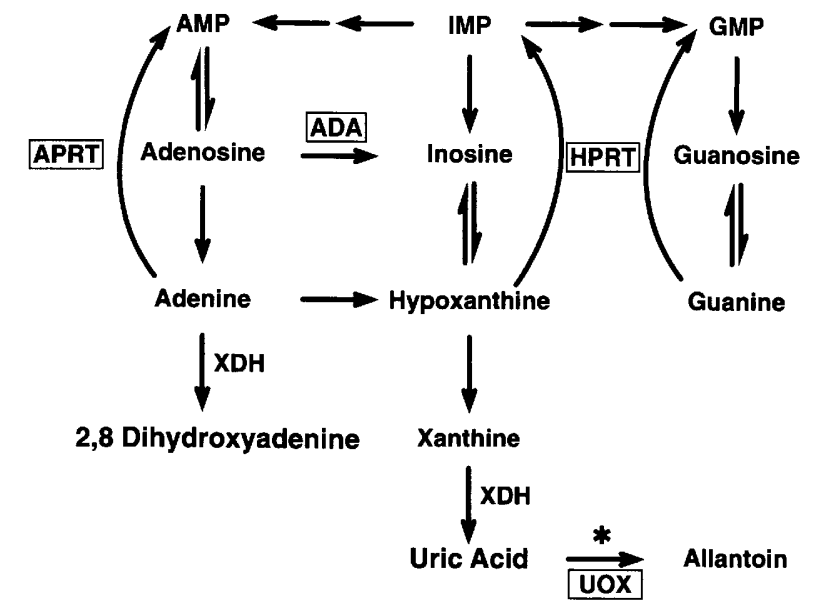

Figure 5. Pathways for purine metabolism. Mutations in each of the genes encoding the boxed enzymes have been created by gene targeting and are models for human diseases. The abbreviation and table for each of these enzymes is: (APRT) adenine phosphoribosyl transferase (Table 7); (ADA) adenosine deaminase (Table 6); (HPRT) hypoxanthine guanine phosoribosyl transferase (Table 7); (UOX) urate oxidase (Table 7). The asterisk denotes a pathway that is not used in humans because UOX is nonfunctional. (AMP) adenosine monophosphate; (IMP) inosine monophosphate; (GMP) guanosine monophosphate; (XDH) xanthine dehydrogenase.

these mice as models for Lesch-Nyhan disease. However, these results are at odds with those of Engle et al. (1996b) who have shown recently that mice mutated in both Hprt and Aprt lack the behavioral abnormalities seen in Lesch-Nyhan patients. The second possible explanation for the lack of apparent phenotype in Hprt mutant mice is that uric acid may not accumulate because of the activity of urate oxidase (Uox), a nonfunctional enzyme in humans (MIM 191540), that converts uric acid to allantoin (see Fig. 5). Uox has been knocked out in the mouse and homozygosity results in pronounced hyperuricemia and renal nephropathy (Wu et al. 1994). The availability of these mice makes it possible to genetically test whether uric acid accumulation alters the Hprt phenotype in mice.

\section{Menkes disease}

Copper is an essential trace element that is a cofactor for numerous enzymatic reactions. Because increased or decreased levels of copper have deleterious effects, multiple mechanisms are used to tightly regulate copper homeostasis. Menkes disease (MIM 304150) is an X-linked disorder of copper metabolism that is characterized by neurologic degeneration, connective tissue abnormalities, and brittle, depigmented hair. Mottled $(\mathrm{Mo})$ mice share many genetic, biochemical and phenotypic similarities with humans with Menkes disease and have been proposed as models for this disease. Several groups identified $A T P 7 A$, a gene responsible for copper efflux, as a strong candidate for Menkes disease (for review, see
Hamer 1993). Subsequent cloning of the mouse homolog $($ Atp $7 a)$ and identification of intragenic mutations in several alleles of Mo (Levinson et al. 1994; Mercer et al. 1994) provided conclusive evidence that Menkes patients and Mo mice are deficient in homologous genes.

Mutations at the Mo locus occur frequently and at least 16 different alleles have been reported (MGD). The hemizygous phenotypes range from prenatal lethality to relatively mild effects on hair color and texture. Two alleles, $M o^{b r}$ and $M o^{b r}$, produce phenotypes that are very similar to Menkes patients. In Menkes patients and in $M o^{b r J}$ males, copper accumulates in the intestines and is not exported to peripheral organs. Much of the copper in the intestines of $\mathrm{Mo}^{\text {brI }}$ mice is bound to metallothioneins (Mt), a group of low-molecular-weight polypeptides that bind to and detoxify copper and other metals. $M t$ is not essential for viability as $M t$ mutant mice have been generated by gene targeting and were shown to have normal lifespans (Masters et al. 1994).

Kelly and Palmiter (1996) have examined further the role of copper metabolism by generating mice that are homozygous for both $M t$ and $M o^{b r I}$ mutations. Contrary to the expectation that the absence of Mt would prolong the survival of $M o^{b r I}$ mice attributable to the lack of copper binding in the intestine, embryonic lethality occurred in the double mutants. Thus, the absence of $\mathrm{Mt}$ exacerbated the $M o^{b r J}$ phenotype. Even more surprisingly, the absence of Mt caused embryonic lethality in females that were heterozygous for $\mathrm{Mo}^{b r I}$, as well as in $M o^{b r I}$ hemizygous males. Based on these results, Kelly and Palmiter (1996) have proposed that Mt normally protects the extraembryonic tissues of the embryo from excessive copper that would accumulate in the absence of functional Atp7a. A similar protective role for Mt may operate in other tissues, such as the intestine and liver, that accumulate high levels of copper in Menkes and Wilson disease (MIM 277900), a related disorder of copper metabolism. This opens the intriguing possibility that MT mutations in humans could either act as modifiers in Menkes disease or other disorders of metal homeostasis, or be directly responsible for such metabolic disorders.

\section{Cystic fibrosis}

Cystic fibrosis (CF; MIM 219700) is the most common lethal disorder of Caucasian populations and is characterized by defective chlorine transport and excess mucus production by epithelial cells. Although mortality in CF patients is attributable primarily to recurring pulmonary infections, CF patients also suffer from intestinal obstruction and inflammation in the airways, pancreas, intestine, bile duct, and vas deferens. The gene responsible for this disorder [cystic fibrosis transmembrane conductance regulator (CFTR)] was isolated in 1989 (for review, see Drumm and Collins 1993). Since that time, several mouse models of CF have been constructed through gene targeting in ES cells (for review, see Dorin 1995). Three different groups have constructed null mutations in Cftr that cause neonatal lethality as the result of severe in- 
testinal obstruction in homozygous mice. The intestinal pathology in these mice is similar to that seen in some CF patients, yet this disease occurs in only a small fraction of CF patients. On the other hand, nearly all CF patients develop lung disease. Although ion transport in the lungs of homozygous null mice is defective, intestinal defects do not allow most of the mice to live long enough to develop lung disease. A less severe Cftr mutant phenotype was reported by Dorin et al. (1992), in which alternative splicing allowed a low level of residual $C f t r$ expression. In these mice the incidence of lethality because of intestinal blockage was greatly reduced, and subsequent analysis of these "leaky" Cftr mutant mice revealed that they had increased susceptibility to bacterially induced lung infections, closely mimicking the pulmonary disease found in CF patients (Davidson et al. 19951.

Several approaches have been used to successfully correct the intestinal and pulmonary defects in mice carrying the severe and leaky Cftr mutations described above (Hyde et al. 1993; Grubb et al. 1994; Zhou et al. 1994). However, the majority of CF patients carry much more subtle CTFR mutations, and strategies that interfere with such mutant proteins may have to be different from those required to correct defects resulting from the absence of normal protein. Recently, two mouse strains that each contain the most common CF mutations have been generated (van Doorninck et al. 1995; Delaney et al. 1996). Importantly, these hypomorphic mutants cause phenotypes that more closely mimic the human disease than Cftr null mutants. In addition to providing invaluable models for testing gene therapy strategies, these strains are the most appropriate models for understanding the molecular and cellular mechanisms of CF.

Recent studies have provided conclusive evidence for at least one unlinked modifier of the Cftr phenotype. In various backcross and intercross progeny from different inbred strains, the survival of mice homozygous for null Cftr mutations varied from within 10 days after birth to $>6$ weeks after birth (Rozmahel et al. 1996). A genome scan using polymorphic markers revealed that a genetic locus located in the proximal region of chromosome 7 is a strong modifier of the null CF phenotype. Within this interval are several intriguing candidate genes that encode proteins that might be expected to affect $C f t r$ function. Further analyses in mice should reveal the identity of the chromosome 7 modifier, and perhaps other modifiers, of the Cftr phenotype that may be directly applicable to treatment of CF.

\section{Atherosclerosis}

The major cause of death in much of the world is attributable to cardiovascular disease induced by atherosclerosis. Although the pathogenesis of atherosclerosis is complex and results from a combination of genetic and environmental (primarily dietary) factors, the best-studied risk factor for atherosclerosis is the level of plasma lipoproteins. The first genetic disorder of cholesterol metabolism to be identified in humans is caused by muta- tions in low density lipoprotein receptor (LDLR; for review, see Goldstein et al. 1995) that cause familial hypercholesterolemia (MIM 143890). Another risk factor for atherosclerosis is hyperlipoproteinemia type III (MIM 107741), in which different allelic forms of APOE are associated with increased incidence of the disease (Mahley and Rall 1995).

Several mouse models have been developed using transgenic and knockout technologies to investigate the role of Apoe and Ldlr in atherosclerosis (Table 7). Mice homozygous for Apoe null mutations develop severe hypercholesterolemia and atherosclerotic lesions at a young age, even when fed a low-fat diet (for review, see Knecht and Glass 1995; Plump and Breslow 1995). A similar but less severe phenotype occurs in mice that have disruptions of Ldlr (for review, see Knecht and Glass 1995). These mice are very useful for understanding how atherosclerotic lesions develop and for testing possible routes of gene therapy (e.g., see Ishibashi et al. 1993; Linton et al. 1995). In addition, the Apoe and Ldlr mutant mice will be useful to test possible interactions between Apoe, Ldlr, and other factors in cholesterol metabolism and atherosclerosis. For example, it has been suggested that Apoe may bind to both Ldlr and a second receptor. Direct evidence supporting this notion has been provided by comparisons of the cholesterol levels of mice homozygous for mutations in Apoe, Ldlr, or both Apoe and Ldlr (Ishibashi et al. 1994). In addition, Smith et al. (1995) have provided evidence that macrophages play a role in development of atherosclerotic lesions by crossing Apoe mice with osteopetrotic (op) mice, which have reduced numbers of tissue macrophages as a result of a mutation in the gene encoding macrophage colonystimulating factor. Finally, two recent papers demonstrate that atherosclerosis in mice can be affected by other genes involved in lipid metabolism. When expressed as transgenes, apoliprotein A-IV la constituent of plasma lipid particles) and lipoprotein lipase (involved in hydrolysis of triglyceride-rich lipoproteins) were able to protect Apoe or Ldlr mice, respectively, from developing atherosclerosis (Duverger et al. 1996; Shimada et al. 1996). Continued studies of these and other mouse loci that affect atherosclerosis (see Table 7) should provide a wealth of information to diagnose and treat the human disease.

\section{Gene therapy in mouse models of metabolic diseases}

Mice that carry the gus ${ }^{m p s}$ locus and humans with mucopolysaccharidoses type VII (MPS VII; MIM 253220) have mutations in the $\beta$-glucuronidase (Gusb) gene and exhibit neural and retinal degeneration, hearing deficiencies, hepatosplenomegaly, and a shortened lifespan (Neufeld and Muenzer 1995). Because gus ${ }^{m p s}$ mice so closely mimic the abnormalities found in MPSVII patients, they make excellent models to test the in vivo efficacy of different therapies. Transplantation of genetically modified bone marrow cells has been used to successfully treat many, but not all, of the symptoms of gus $^{\text {mps }}$ mice (Wolfe et al. 1992; Maréchal et al. 1993). 
However, a major disadvantage of the transplantation procedure is the deleterious side effects of radiation treatment necessary for the transplantation. Alternative methods that obviate the need for radiation treatment have been tested in gus mps mice, including the use of autologous implants of skin fibroblasts (Moullier et al. 19931, replacement therapy with recombinant $\beta$-glucuronidase (Sands et al. 1994), intraocular injections of recombinant adenoviruses (Li and Davidson 1995), and engraftment of a neural progenitor cell line (Snyder et al. 1995). Although each of these individual approaches alleviates symptoms only in a restricted set of tissues, it is possible that a combination of two or more of these approaches will alleviate all of the symptoms of gus ${ }^{m p s}$ mice and, ultimately, humans with MPS VII.

An exciting new approach for gene therapy has been used to correct a deficiency of fumarylacetoacetate hydrolase (Fah), that causes the accumulation of toxic metabolites of tyrosine in hepatocytes. Mice with Fah mutations have a phenotype very similar to that of humans with hereditary tyrosinemia type 1 (HT1; MIM 276700), and in both cases, severe hepatic dysfunction causes neonatal lethality (Klebig et al. 1992; Grompe et al. 1993). A strategy that was based, in part, on previous observations made in a mouse model of transgene-induced liver disease (for review, see Wilson 1996) has been used in mice to correct the Fah phenotype (Overturf et al. 1996). These authors showed that wild-type liver cells exhibited a selective growth advantage in vivo and that they could repopulate the liver of Fah mutant mice, thereby restoring liver function and viability. Although such in vivo selection may be restricted to certain types of cells and phenotypic consequences, Overturf et al. (1996) have suggested a number of diseases of the liver and other organs that may be treatable with this method.

\section{Diseases with polygenic etiology}

Many of the most common and clinically important medical disorders in humans arise as the result of coinheritance of a number of different genes. Such polygenic traits are not inherited in a simple Mendelian manner like monogenic traits, and linkage analysis to map and identify the former traits is much more complicated. This situation is further complicated by the multifactorial nature of polygenic traits; that is, they often are influenced by environmental, as well as genetic, factors. The mouse is the most promising experimental mammal for modeling these complex diseases as well as for mapping genetic loci affecting the probability of appearance and severity of these diseases and eventually identifying the genes and allelic forms of genes involved in these diseases. In Part I of this review, we outlined some of the advantages of and methods used for analysis of polygenic traits in mice. Enough phenotypic variation exists among inbred mouse strains to find appropriate models for many of the polygenic, multifactorial human diseases. In addition, the availability of a dense set of genetic markers that are easily typed in the mouse allows the whole genome to be scanned for associations (i.e., linkage) with the disease phenotype. Lastly, environmental influences can be controlled easily and manipulated in studies with mice.

Table 8 lists some of the polygenic diseases, modeled in the mouse, for which substantial progress has been made recently. The analysis of other polygenic traits in the mouse has been reviewed recently by Frankel (1995). Many of these complex traits are associated with extreme values for certain quantifiable traits. For example, reductions in cholesterol level are associated with protection from coronary heart disease (for review, see Marchioli et al. 1996). Genes that contribute to these quantifiable traits are called quantitative trait loci (QTL). Mapping QTLs has been at the forefront of recent progress in mouse models of polygenic human disease.

\section{Asthma}

In humans, linkage analysis has suggested that asthma can be inherited as a polygenic trait or as a monogenic, dominant trait with incomplete penetrance (Townley et al. 1986; Longo et al. 1987). However, these studies are very difficult to perform in humans because asthma is affected significantly by environmental influences that are difficult to control. Such environmental influences may be minimized in mouse models by housing the mice in a controlled environment under specific pathogen-free conditions.

A critical feature of asthma is airway hyper-responsiveness, which can be measured as the amount of cholinergic agonist required to double pulmonary airway resistance $\left(E D_{200} R_{L}\right)$. Mice from the $A / J$ strain, but not the $\mathrm{C} 57 \mathrm{BL} / 6 \mathrm{~J}(\mathrm{~B} 6)$ strain, have low $\mathrm{ED}_{200} \mathrm{R}_{\mathrm{L}}$ values similar to those seen in human asthma patients (De Sanctis et al. 1995). This trait appears to display dominant inheritance as the $F_{1}$ progeny of these two strains displayed $E D_{200} R_{L}$ values similar to that of $\mathrm{A} / \mathrm{J}$ mice. Furthermore, a continuous distribution of $\mathrm{ED}_{200} \mathrm{R}_{\mathrm{L}}$ values was observed in 19 different $\mathrm{AXB}$ recombinant inbred strains, suggesting that airway hyper-responsiveness is under polygenic control. Individual loci that influence $E_{200} R_{L}$ values were mapped in $\left[(\mathrm{B} 6 \times \mathrm{A} / \mathrm{J}) \mathrm{F}_{1} \times \mathrm{B} 6\right]$ backcross mice using simple sequence length polymorphisms (SSLPs). These studies revealed three loci affecting airway responsiveness, called bronchial hyper-responsiveness types 1,2 , and 3 (Bhr1, Bhr2, and Bhr3) (De Sanctis et al. 1995). Interestingly, all three of these loci lie near candidate genes implicated in the etiology or pathology of asthma. Recently, airway hyper-responsiveness was found in mice that are homozygous for a null mutation in the integrin $\beta 6$ subunit gene (Itbg6) (Huang et al. 1996). This phenotype was observed in mice of a mixed background of 129 and B6 strains. Although Itbg6 does not map near any of the $B h r$ loci, it will be of interest to determine whether the $I t b g 6$ phenotype is altered when on a pure B6 or A/J background.

\section{Substance abuse}

People with severe substance abuse problems often are 
Table 8. Mouse models of human diseases with polygenic etiology

\begin{tabular}{|c|c|c|c|c|c|}
\hline $\begin{array}{l}\text { Polygenic } \\
\text { disease }\end{array}$ & $\begin{array}{l}\text { Susceptible } \\
\text { strain(s) }\end{array}$ & $\begin{array}{c}\text { Resistant } \\
\text { strain(s) }\end{array}$ & Crosses $^{a}$ & $\begin{array}{l}\text { Loci mapped } \\
{\text { (chromosome })^{\mathrm{b}}}\end{array}$ & Selected references ${ }^{\mathrm{C}}$ \\
\hline Alcohol preference & $\mathrm{C} 57 \mathrm{BL} / 6$ & $\mathrm{DBA} / 2 \mathrm{~J}$ & RI, backcross & $A l c p(2), A l c p 2(11)$ & $\begin{array}{l}{ }^{\star} \text { Crabbe et al. (1994); } \\
\text { Melo et al. (1996) }\end{array}$ \\
\hline $\begin{array}{l}\text { Asthma (airway } \\
\text { hyper-responsiveness) }\end{array}$ & $\mathrm{A} / \mathrm{J}$ & $\mathrm{C} 57 \mathrm{BL} / 6 \mathrm{~J}$ & RI, backcross & $\begin{array}{c}B h r 1(2), B h r 2(15), \\
B h r 3(17)\end{array}$ & $\begin{array}{l}\text { De Sanctis et al. } \\
\text { (1995) }\end{array}$ \\
\hline Atherosclerosis & $\begin{array}{l}\text { C57BL/6, } \\
\text { SWR, SM }\end{array}$ & $\mathrm{C} 3 \mathrm{H} / \mathrm{HeJ}, \mathrm{BALB} / \mathrm{c}, \mathrm{A} / \mathrm{J}$ & RI, backcross & $\begin{array}{l}\text { Ath1(1), Ath2(?), } \\
\text { Ath3(7) }\end{array}$ & ${ }^{\star}$ Paigen et al. (1994) \\
\hline $\begin{array}{l}\text { Benign and malignant } \\
\text { skin tumorigenesis }\end{array}$ & $\begin{array}{l}\text { NIH (Mus } \\
\quad \text { musculus) }\end{array}$ & Mus spretus & Backcross & $(7),(7),(5)^{\mathrm{d}}$ & Nagase et al. (1995) \\
\hline $\begin{array}{l}\text { Insulin-dependent } \\
\text { diabetes mellitus }\end{array}$ & NOD & $\begin{array}{l}\mathrm{BALB} / \mathrm{c} ; \mathrm{C} 57 \mathrm{BL} / 6 \mathrm{~J}, \\
\mathrm{C} 3 \mathrm{H} / \mathrm{He}, \mathrm{C} 57 \mathrm{BL} / 10, \\
\mathrm{NON}, \mathrm{PWK}, \mathrm{SJL}, \\
\text { Mus spretus }\end{array}$ & $\begin{array}{c}\text { Backcross, } \mathrm{F}_{2} \\
\text { congenic }\end{array}$ & $\begin{array}{l}\text { Idd1-Idd15 (multiple } \\
\text { chromosomes) }\end{array}$ & $\begin{array}{l}{ }^{*} \text { Wickler et al. }(1995) ; \\
{ }^{\star} \text { Vyse and Todd } \\
(1996)\end{array}$ \\
\hline Morphine preference & C57BL/6J & $\mathrm{DBA} / 2 \mathrm{~J}$ & $\mathrm{RI}, \mathrm{F}_{2}$ & $(1),(6),(10)$ & $\begin{array}{l}\text { Berrettini et al. (1994); } \\
{ }^{\star} \text { Crabbe et al. } \\
(1994)\end{array}$ \\
\hline
\end{tabular}

A similar, but much more complete table can be found in a review by Frankel (1995). Here we have included models described in the text and some new models not discussed by Frankel (1995).

${ }^{a}$ The type of mouse cross or crosses that have been used to map susceptibility loci for the disease; $(R I)$ recombinant inbred lines; $\left(\mathrm{F}_{2}\right)$ an $\mathrm{F}_{1}$ intercross [e.g., $\left.(\mathrm{A} \times \mathrm{B}) \mathrm{F}_{1} \times(\mathrm{A} \times \mathrm{B}) \mathrm{F}_{1}\right)$ to generate the $\mathrm{F}_{2}$ generation; (backcross) first-generation backcross $\left[\mathrm{e} . \mathrm{g}\right.$., $\left.\left.(\mathrm{A} \times \mathrm{B}) \mathrm{F}_{1} \times \mathrm{A}\right)\right)_{\text {; }}$ (congenic) > 10 successive backcrosses selected for a particular trait or chromosomal region.

${ }^{\mathrm{b}}$ The name (if names were designated) and chromosome (in parentheses) of published murine loci is given.

${ }^{c}$ Reviews are indicated with an asterisk.

${ }^{\mathrm{d}}$ A total of three different loci controlling susceptibility to skin tumors have been identified; two loci that affect susceptibility to benign skin tumors have been mapped to chromosome 7 and one locus affecting susceptibility to benign and malignant skin tumors has been mapped to chromosome 5 .

addicted to multiple substances. A similar situation occurs in mice and is strain-specific; the B6 strain prefers orally available alcohol, cocaine, and opiates to a much greater extent than other strains. B6 mice will consume 20-30 times as much morphine and 10 times as much alcohol as DBA/2J (D2) mice, and these two strains of mice have been used as models of substance abuse for more than 30 years (Crabbe et al. 1994). To map loci associated with morphine preference in the mouse, QTL analysis of $\mathrm{F}_{2}$ progeny from a B6 $\times \mathrm{D} 2$ intercross was conducted (Berrettini et al. 1994). Three QTLs on mouse chromosomes 1,6 , and 10 were identified that together explain $85 \%$ of the genetic variance in morphine consumption between B6 and D2 mice. More recently, Melo et al. (1996) have mapped QTLs for alcohol preference in $\mathrm{N}_{2}$ mice from two backcrosses, $\left[(\mathrm{B} 6 \times \mathrm{D} 2) \mathrm{F}_{1} \times \mathrm{B} 6\right]$ and $\left[\mathrm{B} 6 \times\left(\mathrm{B} 6 \times \mathrm{D}_{2}\right) \mathrm{F}_{1}\right]$. These mapping studies revealed two recessive loci that control alcohol preference in $\mathrm{B} 6$ mice; Alcp1 is on chromosome 2 and Alcp2 is on chromosome 11 , and each accounts for $23 \%$ of the genetic variance observed in the backcrosses. Interestingly, each of these QTLs is sex-restricted with alcohol preference cosegregating with Alcp1 in males and with Alcp2 in females. Each of the Alcp1 and Alcp2 intervals contains potential candidate genes that may now be tested directly for their effects on alcohol preference. No associations were found with the morphine preference QTLs described by Berrettini et al. (1994), suggesting that alcohol and morphine preferences are genetically distinct traits. Given the widespread and devastating results of addiction to these substances in humans, the identification of the mouse genes represented by each of these QTLs could be of tremendous importance to human health.

\section{Diabetes}

Environmental and genetic factors contribute to the development of insulin-dependent diabetes mellitus (IDDM; MIM 222100) or type 1 diabetes, an autoimmune disease in which cells of the immune system infiltrate the pancreas, invade the islets of Langerhans, and destroy insulin-producing $\beta$ cells (for review, see Tisch and McDevitt 1996). The nonobese diabetic (NOD) mouse strain spontaneously develops a disease very similar to human IDDM. NOD mice carry a diabetes-sensitivity allele at the Idd1 locus. This locus is located in the mouse major histocompatibility complex (MHC) and is analogous to human IDDM association with certain human lymphocyte antigen (HLA) haplotypes. Experimental crosses between NOD and diabetes-resistant strains such as $\mathrm{B} 6, \mathrm{C} 3 \mathrm{H}$, and NON have allowed the identification of a remarkable number of non-MHC loci, called Idd2-Idd15, that affect susceptibility to type 1 diabetes (for review, see Wicker et al. 1995; Vyse and Todd 1996). The currently favored model for the action of these susceptibility genes is that no single allele is sufficient or necessary (other than Idd1) for disease to develop. The more susceptibility alleles at unlinked loci an individual has, the more likely that individual will develop type 1 
diabetes. Therefore, more than one combination of alleles can result in disease.

Although none of the non-MHC susceptibility genes have been identified, construction of congenic strains, with increasingly narrow chromosomal regions donated from sensitive strains, has allowed the map position of some of these loci to be refined to regions as small as a few centiMorgans. Intriguingly, some of the Idd loci map within intervals associated with susceptibility to other mouse autoimmune disorders, such as systemic lupus erythromatosis (e.g., Idd11 and Sle2) and a multiple sclerosis-like syndrome (e.g., Idd10 and eae3), as well as have human counterparts that affect susceptibility to IDDM (e.g., Idd5 and IDDM7) (for review, see Vyse and Todd 1996).

\section{Concluding remarks}

In reading Part II of this review it should be apparent that mouse models are having, and will continue to have, an enormous impact on human disease research. Not only do these disease models in many instances faithfully recapitulate the phenotype of the human disease, but they allow one to study the disease on a uniform genetic background. Even the few models that do not reproduce the human phenotypes exactly are still of considerable interest because they may be indicative of important interspecies differences. Alternatively, they may be attributable to mutational differences (i.e., recessive, null mutations in mice vs. dominant, GOF in humans) that are crucial for interpreting the biological function of the protein. As more and more models of monogenic traits become available, it will be possible to assess the epistatic and interactive relationships of various genes and their encoded proteins. Even more important, it is often possible to identify and map genes that modify the nature or severity of a given disease by breeding the mutated gene onto different inbred strain backgrounds. The identification and cloning of these modifier genes offers great potential for future disease gene research. Mouse models also offer an important resource for testing different treatment strategies before they are introduced into the clinic, and a number of mouse models that have been particularly useful in this regard are listed in the review. Finally, it should be apparent to everyone in the field that we are rapidly moving from an era focused largely on monogenic diseases to a more complicated, but potentially even more rewarding, era of polygenic diseases. Because of the tremendous genetic resources that are currently available, mice are well poised to lead us into this new era of disease research.

\section{Acknowledgments}

We are grateful to Linda Brubaker for help in preparing the manuscript and Richard Frederickson for preparing the artwork. The authors were supported by the National Cancer Institute under contract with ABL. D.A.L. is a Leukemia Society of America Fellow. We dedicate this review to the memory of Edward Birkenmeier, a friend and former Senior Staff Scientist at the Jackson Laboratory, who made many significant contributions to this area of research.

\section{References}

Adlkofer, K., R. Martini, A. Aguzzi, J. Zielasek, K.V. Toyka, and U. Suter. 1995. Hypermyelination and demyelinating peripheral neuropathy in Pmp22-deficient mice. Nature Genet. 11: $274-280$.

Anderson, D.C. and T.A. Springer. 1987. Leukocyte adhesion deficiency: An inherited defect in the Mac-1, LFA-1, and p150,95 glycoproteins. Annu. Rev. Med. 38: 175-194.

Andrikopolous, K., X. Liu, D.R. Keene, R. Jaenisch, and F. Ramirez. 1995. Targeted mutation in the col5a2 gene reveals a regulatory role for type $\mathrm{V}$ collagen during matrix assembly. Nature Genet. 9: 31-36.

Avraham, K.B., T. Hasson, K.P. Steel, D.M. Kingsley, L.B. Russell, M.S. Mooseker, N.G. Copeland, and N.A. Jenkins. 1995. The mouse Snell's waltzer deafness gene encodes an unconventional myosin required for structural integrity of inner ear hair cells. Nature Genet. 11: 369-375.

Baker, S.M., C.E. Bronner, L. Zhang, A.W. Plug, M. Robatzek, G. Warren, E.A. Elliott, J. Yu, T. Ashley, N. Arnheim, R.A. Flavell, and R.M. Liskay. 1995. Male mice defective in the DNA mismatch repair gene PMS2 exhibit abnormal chromosome synapsis in meiosis. Cell 82: 309-319.

Baker, S.M., A.W. Plug, T.A. Prolla, C.E. Bronner, A.C. Harris, X. Yao, D.-M. Christie, C. Monell, N. Arnheim, A. Bradley, T. Ashley and R.M. Liskay. 1996. Involvement of mouse Mlh1 in DNA mismatch repair and meiotic crossing over. Nature Genet. 13: 336-342.

Bakker, C.E., C. Verheij, R. Willemsen, R. Van der Helm, F. Oerlemans, M. Vermey, A. Bygrave, A.T. Hoogeveen, B.A. Oostra, et al. 1994. Fmr1 knockout mice: A model to study fragile X mental retardation. Cell 78: 23-33.

Baldwin, C.T., C.F. Hoth, R.A. Macina, and A. Milunsky. 1995. Mutations in PAX3 that cause Waardenburg syndrome type I: Ten new mutations and review of the literature. Am. I. Med. Genet. 58: 115-122.

Barbosa, M.D.F.S., Q.A. Nguyen, V.T. Tchernev, J.A. Ashley, J.C. Detter, S.M. Blaydes, S.J. Brandt, D. Chotai, C. Hodgman, R.C.E. Solari, M. Lovett, and S.F. Kingsmore. 1996. Identification of the homologous beige and Chediak-Higashi syndrome genes. Nature 382: 262-265.

Barlow, C., S. Hirotsune, R. Paylor, M. Liyanage, M. Eckhaus, F. Collins, Y. Shiloh, J.N. Crawley, T. Ried, D. Tagle, and A. Wynshaw-Boris. 1996. Atm-deficient mice: A paradigm of ataxia telangiectasia. Cell 86: 159-171.

Barrat, F.J., L. Auloge, E. Pastural, R.D. Lagelouse, E. Vilmer, A.J. Cant, J. Weissenbach, D. Le Paslier, A. Fischer, and B. de Saint Basile. 1996. Genetic and physical mapping of the Chediak-Higashi syndrome on chromosome 1q42-43. Am. J. Hum. Genet. 59: 625-632.

Barsh, G.S. 1996. The genetics of pigmentation: From fancy genes to complex traits. Trends Genet. 12: 299-305.

Baynash, A.G., K. Hosoda, A. Giaid, J.A. Richardson, N. Emoto, R.E. Hammer, and M. Yanagisawa. 1994. Interaction of endothelin-3 with endothelin-B receptor is essential for development of epidermal melanocytes and enteric neurons. Cell 79: 1277-1285.

Becker, M.A. and B.J. Roessler. 1995. Hyperuricemia and gout. In The metabolic and molecular bases of inherited disease, 7th edition (ed. C.R. Scriver, A.L. Beaudet, W.S. Sly, and D. Valle), pp. 1655-1677. McGraw-Hill, New York, NY.

Becker, P.S. and S.E. Lux. 1995. Hereditary spherocytosis and 
hereditary elliptocytosis. In The metabolic and molecular bases of inherited disease, 7th edition (ed. C.R. Scriver, A.L. Beaudet, W.S. Sly, and D. Valle), pp. 3513-3560. McGrawHill, New York, NY.

Bedell, M.A., N.A. Jenkins, and N.G. Copeland. 1997. Mouse models of human disease. Part I: Techniques and resources for genetic analysis in mice: Genes \& Dev. (this issue).

Bellus, G.A., I. McIntosh, E.A. Smith, A.S. Aylsworth, I. Kaitila, W.A. Horton, G.A. Greenhaw, J.T. Hecht, and C.A. Francomano. 1995. A recurrent mutation in the tyrosine kinase domain of fibroblast growth factor receptor 3 causes hypochondroplasia. Nature Genet. 10: 357-359.

Bennett, J., T. Tanabe, D. Sun, Y. Zeng, H. Kjeldbye, P. Gouras, and A.M. Maguire. 1996. Photoreceptor cell rescue in retinal degeneration $(r d)$ mice by in vivo gene therapy. Nature Med. 2: 649-654.

Berrettini, W.H., T.N. Ferraro, R.C. Alexander, A.M. Buchberg, and W.H. Vogel. 1994. Quantitative trait loci mapping of three loci controlling morphine preference using inbred mouse strains. Nature Genet. 7: 54-58.

Berry, C.L., C. Vogler, N.J. Galvin, E.H. Birkenmeier, and W.S. Sly. 1994. Pathology of the ear in the murine mucopolysaccharidosis type VII. Morphologic correlates of hearing loss. Lab. Invest. 71: 438-445.

Besmer, P., K. Manova, R. Duttlinger, E.J. Huang, A. Packer, C. Gyssler, and R.F. Bachvarova. 1993. The kit-ligand /steel factor) and its receptor $c$-kit/W: Pleiotropic roles in gametogenesis and melanogenesis. Development (Suppl.): 125-137.

Bi, L., A.M. Lawler, S.E. Antonarakis, K.A. High, J.D. Gearhart, and H.H. Kazazian, Jr. 1995. Targeted disruption of the mouse factor VIII gene produces a model of haemophilia A. Nature Genet. 10: 119-121.

Bingham, P.M., M.O. Scott, S. Wang, M.J. McPhaul, E.M. Wilson, J.Y. Garbern, D.E. Merry, and K.H. Fischbeck. 1995. Stability of an expanded trinucleotide repeat in the androgen receptor gene in transgenic mice. Nature Genet. 9: 191-196.

Bloom, M.L., T.M. Kaysser, C.S. Birkenmeier, and J.E. Barker. 1994. The murine mutation jaundiced is caused by replacement of an arginine with a stop codon in the mRNA encoding the ninth repeat of $\beta$-spectrin. Proc. Natl. Acad. Sci. 91: 10099-10103.

Bornstein, P., C.E. McKinney, M.E. LaMarca, S. Winfield, T. Shingu, S. Devarayalu, H.L. Vos, and E.I. Ginns. 1995. Metaxin, a gene contiguous to both thrombospondin 3 and glucocerebrosidase, is required for embryonic development in the mouse: Implications for Gaucher disease. Proc. Nat1. Acad. Sci. 92: 4547-4551.

Boulechfar, S., J. Lamoril, X. Montagutelli, J.L. Guenet, J.C. Deybach, Y. Nordmann, H. Dailey, B. Grandchamp, and H. de Verneuil. 1993. Ferrochelatase structural mutant $\left(\right.$ Fech $\left.^{\mathrm{mlPas}}\right)$ in the house mouse. Genomics 16: 645-648.

Bowes, C., T. Li, M. Danciger, L.C. Baxter, M.L. Applebury, and D.B. Farber. 1990. Retinal degeneration in the $r d$ mouse is caused by a defect in the $\beta$ subunit of rod cGMP-phosphodiesterase. Nature 347: 677-680.

Bowes, C., T. Li, W.N. Frankel, M. Danciger, J.M. Coffin, M.L. Applebury, and D.B. Farber. 1993. Locaiszation of a retroviral element within the $r d$ gene coding for the $\beta$-subunit of cGMP phosphodiesterase. Proc. Nat1. Acad. Sci. 90: 2955-2959.

Bowman, B.H., L. Jansen, F. Yang, G.S. Adrian, M. Zhao, S.S. Atherton, J.M. Buchanan, R. Greene, C. Walter, D.C. Herbert, F.J. Weaker, L.K. Chiodo, K. Kagan-Hallet, and J.E. Hixson. 1995. Discovery of a brain promoter from the human transferrin gene and its utilization for development of transgenic mice that express human apolipoprotein E alleles. Proc. Natl. Acad. Sci. 92: 12115-12119.
Brady, S.T. 1993. Motor neurons and neurofilaments in sickness and in health. Cell 73: 1-3.

Brannan, C.I., A.S. Perkins, K.S. Vogel, N. Ratner, M.L. Nordlund, S.W. Reid, A.M. Buchberg, N.A. Jenkins, L.F. Parada, and N.G. Copeland. 1994. Targeted disruption of the neurofibromatosis type- 1 gene leads to developmental abnormalities in heart and various neural crest-derived tissues. Genes \& Dev. 8: 1019-1029.

Breslow, J.L. 1994. Insights into lipoprotein metabolism from studies in transgenic mice. Annu. Rev. Physiol. 56: 797-810. 1996. Mouse models of atherosclerosis. Science 272: 685-688.

Bronner, C.E., S.M. Baker, P.T. Morrison, G. Warren, L.G. Smith, M.K. Lescoe, M. Kane, C. Earabino, J. Lipford, A. Lindblom, P. Tannergard, R.J. Bollag, A.R. Godwin, D.C. Ward, M. Nordenskjold, R. Fishel, R. Kolodner, and R.M. Liskay. 1994. Mutation in the DNA mismatch repair gene homologue $h M L H 1$ is associated with hereditary non-polyposis colon cancer. Nature 368: 258-261.

Brown, R.H., Jr: 1995. Amyotrophic lateral sclerosis: Recent insights from genetics and transgenic mice. Cell 80: 687-692.

Brusilow, S.W. and A.L. Horwich. 1995. Urea cycle enzymes. In The metabolic and molecular bases of inherited disease, 7 th edition (ed. C.R. Scriver, A.L. Beaudet, W.S. Sly, and D. Valle), pp. 1187-1232. McGraw-Hill, New York, NY.

Bullard, D.C., K. Scharffetter-Kochanek, M.J. McArthur, J.G. Chosay, M.E. McBride, C.A. Montgomery, and A.L. Beaudet. 1996. A polygenic mouse model of psoriasiform skin disease in CD-18-deficient mice. Proc. Natl. Acad. Sci. 93: 21162121.

Burright, E.N., H.B. Clark, A. Servadio, T. Matilla, R.M. Feddersen, W.S. Yunis, L.A. Duvick, H.Y. Zoghbi, and H.T. Orr. 1995. SCA1 transgenic mice: A model for neurodegeneration caused by an expanded CAG trinucleotide repeat. Cell 82: 937-948.

Campbell, K.P. 1995. Three muscular dystrophies: Loss of cytoskeleton-extracellular matrix linkage. Cell 80: 675-679.

Cannon-Albright, L.A. and M.H. Skolnick. 1996. The genetics of familial breast cancer. Semin. Oncol. 23: 1-5.

Chakravarti, A. 1996. Endothelin receptor-mediated signaling in Hirschsprung disease. Hum. Mol. Genet. 5: 303-307.

Chapman, V.M., D.R. Miller, D. Armstrong, and C.T. Caskey. 1989. Recovery of induced mutations for X chromosomelinked muscular dystrophy in mice. Proc. Natl. Acad. Sci. 86: 1292-1296.

Chaudhari, N. 1992. A single nucleotide deletion in the skeletal muscle-specific calcium channel transcript of muscular dysgenesis (mdg) mice. J. Biol. Chem. 267: 25636-25639.

Chen, Y.T. and A. Burchell. 1995. Glycogen storage diseases. In The metabolic and molecular bases of inherited disease, 7th edition (ed. C.R. Scriver, A.L. Beaudet, W.S. Sly, and D. Vallel, pp. 935-965. McGraw-Hill, New York, NY.

Chipman, S.D., H.O. Sweet, D.J. McBride, Jr., M.T. Davisson, S.C. Marks, Jr., A.R. Shuldiner, R.J. Wenstrup, D.W. Rowe, and J.R. Shapiro. 1993. Defective proo2(I) collagen synthesis in a recessive mutation in mice: A model of human osteogenesis imperfecta. Proc. Natl. Acad. Sci. 90: 1701-1705.

Ciavatta, D.J., T.M. Ryan, S.C. Farmer, and T.M. Townes. 1995. Mouse model of human $\beta^{\circ}$ thalassemia: Targeted deletion of the mouse $\beta^{\text {maj }}$ - and $\beta^{\text {min }}$-globin genes in embryonic stem cells. Proc. Nat1. Acad. Sci. 92: 9259-9263.

Clarke, A.R. 1995. Murine models of neoplasia: Functional analysis of the tumour suppressor genes $R b-1$ and $p 53$. Cancer Metastasis Rev. 14: 125-148.

Collard, J.-F., F. Cote, and J.-P. Julien. 1995. Defective axonal transport in a transgenic mouse model of amyotrophic lat- 
Bedell et al.

eral sclerosis. Nature 375: 61-64.

Collinge, J., M.A. Whittington, K.C. Sidle, C.J. Smith, M.S. Palmer, A.R. Clarke, and J.G. Jefferys. 1994. Prion protein is necessary for normal synaptic function. Nature 370: 295297.

Collinge, J., M.S. Palmer, K.C.L. Sidle, A.F. Hill, I. Gowland, J. Meads, E. Asante, R. Bradley, L.J. Doey, and P.L. Lantos. 1995. Unaltered susceptibility to BSE in transgenic mice expressing human prion protein. Nature 378: 779-783.

Colvin, J.S., B.A. Bohne, G.W. Harding, D.G. McEwen, and D.M. Ornitz. 1996. Skeletal overgrowth and deafness in mice lacking fibroblast growth factor receptor 3. Nature Genet. 12: 390-397.

Cox, G.A., N.M. Cole, K. Matsumura, S.F. Phelps, S.D. Hauschka, K.P. Campbell, J.A. Faulkner, and J.S. Chamberlain. 1993a. Overexpression of dystrophin in transgenic $m d x$ mice eliminates dystrophic symptoms without toxicity. Nature 364: 725-728.

Cox, G.A., S.F. Phelps, V.M. Chapman, and J.S. Chamberlain. 1993b. New mdx mutation disrupts expression of muscle and nonmuscle isoforms of dystrophin. Nature Genet. 4: 8793.

Cox, G.A., Y. Sunada, K.P. Campbell, and J.S. Chamberlain. 1994. Dp71 can restore the dystrophin-associated glycoprotein complex in muscle but fails to prevent dystrophy. $\mathrm{Na}$ ture Genet. 8: 333-339.

Crabbe, J.C., J.K. Belknap, and K.J. Buck. 1994. Genetic animal models of alcohol and drug abuse. Science 264: 1715-1723.

d'Azzo, A., G. Andria, P. Strisciuglio, and H. Galjaard. 1995. Galactosialidosis. In The metabolic and molecular bases of inherited disease, 7 th edition (ed. C.R. Scriver, A.L. Beaudet, W.S. Sly, and D. Vallel, pp. 2825-2837. McGraw-Hill, New York, NY.

Das, S., B. Levinson, C. Vulpe, S. Whitney, J. Gitschier, and S. Packman. 1995. Similar splicing mutations of the Menkes/ Mottled copper-transporting ATPase gene in occipital horn syndrome and the blotchy mouse. Am. I. Hum. Genet. 56: $570-576$.

Davidson, D.J., J.R. Dorin, G. McLachlan, V. Ranaldi, D. Lamb, C. Doherty, J. Govan, and D.J. Porteous. 1995. Lung disease in the cystic fibrosis mouse exposed to bacterial pathogens. Nature Genet. 9: 351-357.

Deconinck, N., T. Ragot, G. Maréchal, M. Perricaudet, and J.M. Gillis. 1996. Functional protection of dystrophic mouse ( $m d x \mid$ muscles after adenovirus-mediated transfer of a dystrophin minigene. Proc. Nat1. Acad. Sci. 93: 3570-3574.

Delaney, S.J., E.W.F.W. Alton, S.N. Smith, D.P. Lunn, R. Farley, P.K. Lovelock, S.A. Thomson, D.A. Hume, D. Lamb, D.J. Porteous, J.R. Dorin, and B.J. Wainwright. 1996. Cystic fibrosis mice carrying the missense mutation G551D replicate human genotype-phenotype correlations. EMBO $J$. 15: 955 963.

Deng, C.-X., A. Wynshaw-Boris, M.M. Shen, C. Daugherty, D.M. Ornitz, and P. Leder. 1994. Murine FGFR-1 is required for early postimplantation growth and axial organization. Genes \& Dev. 8: 3045-3057.

Deng, C.-X., A. Wynshaw-Boris, F. Zhou, A. Kuo, and P. Leder. 1996. Fibroblast growth factor receptor 3 is a negative regulator of bone growth. Cell 84: 911-921.

De Sanctis, G.T., M. Merchant, D.R. Beier, R.D. Dredge, J.K. Grobholz, T.R. Martin, E.S. Lander, and J.M. Drazen. 1995. Quantitative locus analysis of airway hyperresponsiveness in A/J and C57BL/6J mice. Nature Genet. 11: 150-154.

de Wind, N., M. Dekker, A. Berns, M. Radman, and H. te Riele. 1995. Inactivation of the mouse Msh2 gene results in mismatch repair deficiency, methylation tolerance, hyper- recombination, and predisposition to cancer. Cell 82: 321330.

Dietrich, W.F., E.S. Lander, J.S. Smith, A.R. Moser, K.A. Gould, C. Luongo, N. Borenstein, and W. Dove. 1993. Genetic identification of $M o m-1$, a major modifier locus affecting Mininduced intestinal neoplasia in the mouse. Cell 75: 631-639.

DiSanto, J.P., W. Müller, D. Guy-Grand, A. Fischer, and K. Rajewsky. 1995. Lymphoid development in mice with a targeted deletion of the interleukin 2 receptor $\gamma$ chain. Proc. Natl. Acad. Sci. 92: 377-381.

Dollé, P., A. Dierich, M. LeMeur, T. Schimmang, B. Schuhbaur, P. Chambon, and D. Duboule. 1993. Disruption of the Hoxd13 gene induces localized heterochrony leading to mice with neotenic limbs. Cell 75: 431-441.

Donis-Keller, H., S. Dou, D. Chi, K.M. Carlson, K. Toshima, T.C. Lairmore, J.R. Howe, J.F. Moley, P. Goodfellow, and S.A. Wells, Jr. 1993. Mutations in the RET proto-oncogene are associated with MEN 2A and FMTC. Hum. Mol. Genet. 2: 851-856.

Dorin, J.R. 1995. Development of mouse models for cystic fibrosis. J. Inher. Metab. Dis. 18: 495-500.

Dorin, J.R., P. Dickinson, E.W.F.W. Alton, S.N. Smith, D.M. Geddes, B.J. Stevenson, W.L. Kimber, S. Fleming, A.R. Clarke, M.L. Hooper, L. Anderson, R.S.P. Beddington, and D.J. Porteous. 1992. Cystic fibrosis in the mouse by targeted insertional mutagenesis. Nature 359: 211-215.

Drumm, M.L. and F.S. Collins. 1993. Molecular biology of cystic fibrosis. Mol. Genet. Med. 3: 33-68.

Duprez, L., J. Parma, J. Van Sande, A. Allgeier, J. Leclère, C. Schvartz, M.-J. Delisle, M. Decoulx, J. Orgiazzi, J. Dumont, and G. Vassart. 1994. Germline mutations in the thyrotropin receptor gene cause non-autoimmune autosomal dominant hyperthyroidism. Nature Genet. 7: 396-401.

Duverger, N., G. Tremp, J.M. Caillaud, F. Emmanuel, G. Castro, J.C. Fruchart, A. Steinmetz, and P. Denefle. 1996. Protection against atherogenesis in mice mediated by human apoliproprotein A-IV. Science 273: 966-968.

Duyao, M.P., A.B. Auerbach, A. Ryan, F. Persichetti, G.T. Barnes, S.M. McNeil, P. Ge, J.-P. Vonsattel, J.F. Gusella, A.L. Joyner, and M.E. MacDonald. 1995. Inactivation of the mouse Huntington's disease gene homolog Hdh. Science 269: 407-410.

Eber, S.W., J.M. Gonzalez, M.L. Lux, A.L. Scarpa, W.T. Tse, M. Dornwell, J. Herbers, W. Kugler, R. Ozcan, A. Pekrun, P.G. Gallagher, W. Schröter, B.G. Forget, and S.E. Lux. 1996. Ankyrin-1 mutations are a major cause of dominant and recessive hereditary spherocytosis. Nature Genet. 13: 214-218.

Edery, P., T. Attié, I. Amiel, A. Pelet, C. Eng, R.M.W. Hofstra, H. Martelli, C. Bidaud, A. Munnich, and S. Lyonnet. 1996. Mutation of the endothelin-3 gene in the Waardenburg-Hirschsprung disease (Shah-Waardenburg syndrome). Nature Genet. 12: 442-444.

Engle, S.J., M.G. Stockelman, J. Chen, G. Boivin, M.-N. Yum, P.M. Davies, M.Y. Ying, A. Sahota, H.A. Simmonds, P.J. Stambrook, and J.A. Tischfield. 1996a. Adenine phosphoribosyltransferase-deficient mice develop 2,8-dihydroxyadenine nephrolithiasis. Proc. Nat1. Acad. Sci. 93: 5307-5312.

Engle, S.J., D.E. Womer, P.M. Davies, G. Boivin, A. Sahota, H.A. Simmonds, P.J. Stambrook, and J.A. Tischfield. 1996b. HPRT-APRT deficient mice are not a model for LeschNyhan syndrome. Hum. Mol. Genet. 5: 1607-1610.

Ezoe, K., S.A. Holmes, L. Ho, C.P. Bennett, J.L. Bolognia, L. Brueton, J. Burn, R. Falabella, E.M. Gatto, N. Ishii, C. Moss, M.R. Pittelkow, E. Thompson, K.A. Ward, and R.A. Spritz. 1995. Novel mutations and deletions of the KIT (steel factor receptor) gene in human piebaldism. Am. J. Hum. Genet. 
56: $58-66$

Fabry, M.E. 1993. Transgenic animal models of sickle cell disease. Experientia 49: 28-36.

Fabry, M.E., A. Sengupta, S.M. Suzuka, F. Costantini, E.M. Rubin, J. Hofrichter, G. Christoph, E. Manci, D. Culberson S.M. Factor, and R.L. Nagel. 1995. A second generation transgenic mouse model expressing both hemoglobin $S$ $(\mathrm{HbS})$ and Hbs-Antilles results in increased phenotypic severity. Blood 86: 2419-2428.

Farese, R.V., Jr., S.L. Ruland, L.M. Flynn, R.P. Stokowski, and S.G. Young. 1995. Knockout of the mouse apolipoprotein B gene results in embryonic lethality in homozygotes and protection against diet-induced hypercholesterolemia in heterozygotes. Proc. Natl. Acad. Sci. 92: 1774-1778.

Farrington, M., L.S. Grosmaire, S. Nonoyama, S.H. Fischer, D. Hollenbaugh, J.A. Ledbetter, R.J. Noelle, A. Aruffo, and H.D. Ochs. 1994. CD40 ligand expression is defective in a subset of patients with common variable immunodeficiency. Proc. Nat1. Acad. Sci. 91: 1099-1103.

Fässler, R., P.N.J. Schnegelsberg, I. Dausman, T. Shinya, Y. Muragaki, M.T. McCarthy, B.R. Olsen, and R. Jaenisch. 1994. Mice lacking $\alpha 1$ (IX) collagen develop noninflammatory degenerative joint disease. Proc. Natl. Acad. Sci. 91: 50705074.

Figlewicz, D.A., A. Krizus, M.G. Martinoli, V. Meininger, M. Dib, G.A. Rouleau, and J.P. Julien. 1994. Variants of the heavy neurofilament subunit are associated with the development of amyotrophic lateral sclerosis. Hum. Mol. Genet. 3: $1757-1761$.

Fishel, R., M.K. Lescoe, M.R.S. Rao, N.G. Copeland, N.A. Jenkins, J. Garber, M. Kane, and R. Kolodner. 1993. The human mutator gene homolog $\mathrm{MSH} 2$ and its association with hereditary nonpolyposis colon cancer. Cell 75: 1027-1038.

Fisher, G.H., F.J. Rosenberg, S.E. Straus, J.K. Dale, L.A. Middelton, A.Y. Lin, W. Strober, M.J. Lenardo, and J.M. Puck. 1995. Dominant interfering Fas gene mutations impair apoptosis in a human autoimmune lymphoproliferative syndrome. Cell 81: 935-946.

Fleischman, R.A. 1992. Human piebald trait resulting from a dominant negative mutant allele of the c-kit membrane receptor gene. J. Clin. Invest. 89: 1713-1717.

-1993. From white spots to stem cells: The role of the Kit receptor in mammalian development. Trends Genet. 9: 285 290.

Frankel, W.N. 1995. Taking stock of complex trait genetics in mice. Trends Genet. 11: 471-477.

Fuchs, E. 1995. Genetic skin disorders of keratin. In The metabolic and molecular bases of inherited disease, 7 th edition (ed. C.R. Scriver, A.L. Beaudet, W.S. Sly, and D. Valle), pp. 4421-4437. McGraw-Hill, New York, NY.

Gal, A., U. Orth, W. Baehr, E. Schwinger, and T. Rosenberg. 1994. Heterozygous missense mutation in the rod cGMP phosphodiesterase $\beta$-subunit gene in autosomal dominant stationary night blindness. Nature Genet. 7: 64-68.

Gallagher, P.G. and B.G. Forget. 1993. Spectrin genes in health and disease. Semin. Hematol. 30: 4-20.

Games, D., D. Adams, R. Alessandrini, R. Barbour, P. Berthelette, C. Blackwell, T. Carr, J. Clemens, T. Donaldson, F. Gillespie, T. Guido, S. Hagoplan, K. Johnson-Wood, K. Khan, M. Lee, P. Leibowitz, I. Lieberburg, S. Little, E. Masliah, L. McConlogue, M. Montoya-Zavala, L. Mucke, L. Paganini, E. Penniman, M. Power, D. Schenk, P. Seubert, B. Snyder, F. Soriano, H. Tan, J. Vitale, S. Wadsworth, B. Wolozin, and J. Zhao. 1995. Alzheimer-type neuropathology in transgenic mice overexpressing V717F $\beta$-amyloid precursor protein. Nature 373: 523-527.
Gaspar, M.-L., T. Meo, P. Bourgarel, J.-L. Guenet, and M. Tosi. 1991. A single base deletion in the Tfm androgen receptor gene creates a short-lived messenger RNA that directs internal translation initiation. Proc. Natl. Acad. Sci. 88: 86068610.

Gibson, F., J. Walsh, P. Mburu, A. Varela, K.A. Brown, M. Antonio, K.W. Belsel, K.P. Steel, and S.D.M. Brown. 1995. A type VII myosin encoded by the mouse deafness gene shaker1. Nature 374: 62-64.

Glaser, T., L. Jepeal, J.G. Edwards, S.R. Young, J. Favor, and R.L. Maas. 1994. PAX6 gene dosage effect in a family with congenital cataracts, aniridia, anophthalmia, and central nervous system defects. Nature Genet. 7: 463-471.

Godfrey, P., J.O. Rahal, W.G. Beamer, N.G. Copeland, N.A. Jenkins, and K.E. Mayo. 1993. GHRH receptor of little mice contains a missense mutation in the extracellular domain that disrupts receptor function. Nature Genet. 4: 227-232.

Goldstein, J.L., H.H. Hobbs, and M.S. Brown. 1995. Familial hypercholesterolemia. In The metabolic and molecular bases of inherited disease, 7 th edition (ed. C.R. Scriver, A.L. Beaudet, W.S. Sly, and D. Valle), pp. 1981-2030. McGrawHill, New York, NY.

Goodfellow, P.J. 1994. Inherited cancers associated with the RET proto-oncogene. Curr. Opin. Genet. Dev. 4: 446-452.

Gowen, L.C., B.L. Johnson, A.M. Latour, K.K. Sulik, and B.H. Koller. 1996. Brca1 deficiency results in early embryonic lethality characterized by neuroepithelial abnormalities. Nature Genet. 12: 191-194.

Greenberg, D.S., Y. Sunada, K.P. Campbell, D. Yaffe, and U. Nudel. 1994. Exogenous Dp71 restores the levels of dystrophin associated proteins but does not alleviate muscle damage in $m d x$ mice. Nature Genet. 8: 340-344.

Griffiths, I.R., P. Montague, and P. Dickinson. 1995. The proteolipid protein gene. Neuropathol. Appl. Neurobiol. 21: 8596.

Grimber, G., C. Galand, M. Garbarz, M.G. Mattei, C. Cavard, A. Zider, P. Blanchet, P. Boivin, P. Briand, and D. Dhermy. 1992. Inherited haemolytic anaemia created by insertional inactivation of the alpha-spectrin gene. Transgenic Res. 1: $268-274$.

Groden, J., A. Thliveris, W. Samowitz, M. Carlson, L. Gelbert, H. Albertsen, G. Joslyn, J. Stevens, L. Spirio, M. Robertson, L. Sargeant, K. Krapcho, E. Wolff, R. Burt, J.P. Hughes, J. Warrington, J. McPherson, J. Wasmuth, D. Le Paslier, H. Abderrahim, D. Cohen, M. Leppert, and R. White. 1991. Identification and characterization of the familial adenomatous polyposis coli gene. Cell 66: 589-600.

Grompe, M., M. Al-Dhalimy, M. Finegold, C.N. Ou, T. Burlingame, N.G. Kennaway, and P. Soriano. 1993. Loss of fumarylacetoacetate hydrolase is responsible for the neonatal hepatic dysfunction phenotype of lethal albino mice. Genes \& Dev. 7: 2298-2307.

Grubb, B.R., R.J. Pickles, H. Ye, J.R. Yankaskas, R.N. Vick, J.F. Engelhardt, J.M. Wilson, L.G. Johnson, and R.C. Boucher. 1994. Inefficient gene transfer by adenovirus vector to cystic fibrosis airway epithelia of mice and humans. Nature 371: 802-806.

Gutmann, D.H. and F.S. Collins. 1993. The neurofibromatosis type 1 gene and its protein product, neurofibromin. Neuron 10: $335-343$.

Hakem, R., J.L. de la Pompa, C. Sirard, R. Mo, M. Woo, A. Haken, A. Wakeham, J. Potter, A. Reitmair, F. Billia, E. Firpo, C.C. Hui, J. Roberts, J. Rossant, and T.W. Mak. 1996. The tumor suppressor gene Brca1 is required for embryonic cellular proliferation in the mouse. Cell 85: 1009-1023.

Hamer, D.H. 1993. "Kinky hair" disease sheds light on copper 
metabolism. Nature Genet. 3: 3-4.

Hanson, I. and V. van Heyningen. 1995. Pax6: More than meets the eye. Trends Genet. 11: 268-272.

Hanson, I.M., J.M. Fletcher, T. Jordan, A. Brown, D. Taylor, R.J. Adams, H.H. Punnett, and V. van Heyningen. 1994. Mutations at the PAX6 locus are found in heterogeneous anterior segment malformations including Peters' anomaly. Nature Genet. 6: 168-173.

Harper, P.S. 1995. Myotonic dystrophy and other autosomal muscular dystrophies. In The metabolic and molecular bases of inherited disease, 7 th edition (ed. C.R. Scriver, A.L. Beaudet, W.S. Sly, and D. Vallel, pp. 4227-4251. McGrawHill, New York, NY.

Harvey, M., H. Vogel, D. Morris, A. Bradley, A. Bernstein, and L.A. Donehower. 1995. A mutant p53 transgene accelerates tumour development in heterozygous but not nullizygous p53-deficient mice. Nature Genet. 9: 305-311.

Helbling-Leclerc, A., X. Zhang, H. Topaloglu, C. Cruaud, F. Tesson, J. Weissenbach, F.M.S. Tomé, K. Schwartz, M. Fardeau, K. Tryggvason, and P. Guicheney. 1995. Mutations in the laminin $\alpha 2$-chain gene (LAMA2) cause merosin-deficient congenital muscular dystrophy. Nature Genet. 11: 216-218.

Hemminki, A., P. Peltomäki, J.-P. Mecklin, H. Järvinen, R. Salovaara, M. Nyström-Lahti, A. De la Chapelle, and L.A. Aaltonen. 1994. Loss of the wild type $M L H 1$ gene is a feature of hereditary nonpolyposis colorectal cancer. Nature Genet. 8: 405-410.

Henthorn, P.S., M. Raducha, K.N. Fedde, M.A. Lafferty, and M.P. Whyte. 1992. Different missense mutations at the tissue-nonspecific alkaline phosphatase gene locus in autosomal recessively inherited forms of mild and severe hypophosphatasia. Proc. Natl. Acad. Sci. 89: 9924-9928.

Higgins, L.S. and B. Cordell. 1995. Transgenic mice and modeling Alzheimer's disease. Rev. Neurosci. 6: 87-96.

Hiltunen, A., M. Metsaranta, P. Virolainen, H.T. Aro, and E. Vuorio. 1994. Retarded chondrogenesis in transgenic mice with a type II collagen defect results in fracture healing abnormalities. Dev. Dyn. 200: 340-349.

Ho, C., D.A. Conner, M.R. Pollack, D.J. Ladd, O. Kifor, H.B. Warren, E.M. Brown, J.G. Seidman, and C.E. Seidman. 1995. A mouse model of human familial hypocalciuric hypercalcemia and neonatal severe hyperparathyroidism. Nature Genet. 11: 389-394.

Hofstra, R.M.W., J. Osinga, G. Tan-Sindhunata, Y. Wu, E.-J. Kamsteeg, R.P. Stulp, C. Van Ravenswaaij-Arts, D. MajoorKrakauer, M. Angrist, A. Chakravarti, C. Meijers, and C.H.C.M. Buys. 1996. A homozygous mutation in the endothelin-3 gene associated with a combined Waardenburg type 2 and Hirschsprung phenotype (Shah-Waardenburg syndrome). Nature Genet. 12: 445-447.

Hollstein, M., D. Sidransky, B. Vogelstein, and C.C. Harris. 1991. p53 mutations in human cancers. Science 253: 49-53.

Hooper, M.L. 1994. The role of the $p 53$ and $R b-1$ genes in cancer, development, and apoptosis. (Suppl.) I. Cell Sci. 18: 13-17.

Hope, J. 1995. Mice and beef and brain diseases. Nature 378: 761-762.

Horinouchi, K., S. Erlich, D.P. Perl, K. Ferlinz, C.L. Bisgaier, K. Sandhoff, R.J. Desnick, C.L. Stewart, and E.H. Schuchman. 1995. Acid sphingomyelinase deficient mice: A model of types A and B Niemann-Pick disease. Nature Genet. 10: $288-293$.

Hosoda, K., R.E. Hammer, J.A. Richardson, A.G. Baynash, J.C. Cheung, A. Giaid, and M. Yanagisawa. 1994. Targeted and natural (piebald-lethal) mutations of endothelin-B receptor gene produce megacolon associated with spotted coat color in mice. Cell 79: 1267-1276.
Hsiao, K.K., D.R. Borchelt, K. Olson, R. Johannsdottir, C. Kitt, W. Yunis, S. Xu, C. Eckman, S. Younkin, D. Price, C. Iadecola, H.B. Clark, and G. Carlson. 1995. Age-related CNS disorder and early death in transgenic FVB/N mice overexpressing Alzheimer amyloid precursor proteins. Neuron 15: $1203-1218$.

Huang, L.S., E. Voyiaziakis, D.F. Markenson, K.A. Sokol, T. Hayek, and J.L. Breslow. 1995. apoB gene knockout in mice results in embryonic lethality in homozygotes and neural tube defects, male infertility and reduced HDL cholesterol ester and apo A-I transport rates in heterozygotes. I. Clin. Invest. 96: 2152-2161.

Huang, P.C., A.E. Gaitan, Y. Hao, R.M. Petters, and F. Wong. 1993. Cellular interactions implicated in the mechanism of photoreceptor degeneration in transgenic mice expressing a mutant rhodopsin gene. Proc. Natl. Acad. Sci. 90: 84848488 .

Huang, X.Z., J.F. Wu, D. Cass, D.J. Erle, D. Corry, S.G. Young, R.V. Farese, Jr., and D. Sheppard. 1996. Inactivation of the integrin $\beta 6$ subunit gene reveals a role of epithelial integrins in regulating inflammation in the lungs and skin. $\%$. Cell. Biol. 133: 921-928.

Hui, C.-C. and A.L. Joyner. 1993. A mouse model of Greig cephalopolysyndactyly syndrome: The extra-toes ${ }^{I}$ mutation contains an intragenic deletion of the Gli3 gene. Nature Genet. 3: 24l-246.

Huizinga, J.D., L. Thuneberg, M. Klüppel, J. Malysz, H.B. Mikkelsen, and A. Bernstein. 1995. W/kit gene required for interstitial cells of Cajal and for intestinal pacemaker activity. Nature 373: 347-349.

Hussussian, C.J., J.P. Struewing, A.M. Goldstein, P.A.T. Higgins, D.S. Ally, M.D. Sheahan, W.H. Clark, Jr., M.A. Tucker, and N.C. Dracopoli. 1994. Germline p16 mutations in familial melanoma. Nature Genet. 8: 15-21.

Hyde, S.C., D.R. Gill, C.F. Higgins, A.E.O. Trezise, L.J. MacVinish, A.W. Cuthbert, R. Ratcliffe, M.J. Evans, and W.H. Colledge. 1993. Correction of the ion transport defect in cystic fibrosis transgenic mice by gene therapy. Nature 362: 250 255.

Ikeda, H., M. Yamaguchi, S. Sugai, Y. Aze, S. Narumiya, and A. Kakizuka. 1996. Expanded polyglutamine in the MachadoJoseph disease protein induces cell death in vitro and in vivo. Nature Genet. 13: 196-202.

Ishibashi, S., M.S. Brown, J.L. Goldstein, R.D. Gerard, R.E. Hammer, and J. Herz. 1993. Hypercholesterolemia in low density lipoprotein receptor knockout mice and its reversal by adenovirus-mediated gene delivery. $J$. Clin. Invest. 92: 883-893.

Ishibashi, S., J. Herz, N. Maeda, J.L. Goldstein, and M.S. Brown. 1994. The two-receptor model of lipoprotein clearance: Tests of the hypothesis in knockout mice lacking the low density lipoprotein receptor, apolipoprotein $\mathrm{E}$, or both proteins. Proc. Natl. Acad. Sci. 91: 4431-4435.

Jabs, E.W., U. Müller, X. Li, L. Ma, W. Luo, I.S. Haworth, I. Klisak, R. Sparkes, M.L. Warman, J.B. Mulliken, M.L. Snead, and R. Maxson. 1993. A mutation in the homeodomain of the human $M S X 2$ gene in a family affected with autosomal dominant craniosynostosis. Cell 75: 443-450.

Jacks, T. 1996. Lessons from the p53 mutant mouse. J. Cancer Res. Clin. Oncol. 122: 319-327.

Jacks, T., T.S. Shih, E.M. Schmitt, R.T. Bronson, A. Bernards, and R.A. Weinberg. 1994. Tumour predisposition in mice heterozygous for a targeted mutation in Nf1. Nature Genet. 7: 353-361.

Jackson, I.J. 1994. Molecular and developmental genetics of mouse coat color. Annu. Rev. Genet. 28: 189-217. 
Jackson, I.J. and S. Raymond. 1994. Manifestations of microphthalmia. Nature Genet. 8: 209-210.

Jansen, G., P.J.T.A. Groenen, D. Bächner, P.H.K. Jap, M. Coerwinkel, F. Oerlemans, W. van den Broek, B. Gohlsch, D. Pette, J.J. Plomp, P.C. Molenaar, M.G.J. Nederhoff, C.J.A. van Echteld, M. Dekker, A. Berns, H. Hameister and B. Wieringa. 1996. Abnormal myotonic dystrophy protein kinase levels produce only mild myopathy in mice. Nature Genet. 13: $316-324$.

Jarolim, P., H.L. Rubin, V. Brabec, and J. Palek. 1995. A nonsense mutation glu1669-to-ter within the regulatory domain of human erythroid ankyrin leads to a selective deficiency of the major ankyrin isoform (band 2.1) and a phenotype of autosomal dominant hereditary spherocytosis. T. Clin. Invest. 95: 941-947.

Jass, J.R., S.M. Stewart, J. Stewart, and M.R. Lane. 1994. Hereditary non-polyposis colorectal cancer: Morphologies, genes and mutations. Mutat. Res. 310: 125-133.

Thiang, S.M., J.E. Sagartz, Q. Tong, J. Parker-Thornburg, C.C. Capen, J.-Y. Cho, S. Xing, and C. Ledent. 1996. Targeted expression of the ret/PTCl oncogene induces papillary thyroid carcinomas. Endocrinology 137: 375-378.

Justice, M.J., C.M. Silan, J.D. Ceci, A.M. Buchberg, N.G. Copeland, and N.A. Jenkins. 1990. A molecular genetic linkage map of mouse chromosome 13 anchored by the beige (bg) and satin (sa) loci. Genomics 6: 341-350.

Kappas, A., S. Sassa, R.A. Galbraith, and Y. Nordmann. 1995. The porphyrias. In The metabolic and molecular bases of inherited disease, 7 th edition /ed. C.R. Scriver, A.L. Beaudet, W.S. Sly, and D. Valle), pp. 2103-2159. McGraw-Hill, New York, NY

Kapur, R.P., D.A. Sweetser, B. Doggett, J.R. Siebert, and R.D. Palmiter. 1995. Intercellular signals downstream of endothelin receptor-B mediate colonization of the large intestine by enteric neuroblasts. Development 121: 3787-3795.

Kawaguchi, Y., T. Okamoto, M. Taniwaki, M. Aizawa, M. Inoue, S. Katayama, H. Kawakami, S. Nakamura, M. Nishimura, I. Akiguchi, J. Kimura, S. Narumiya, and A. Kakizuka. 1994. CAG expansions in a novel gene for Machado-Joseph disease at chromosome 14q32.1. Nature Genet. 8: 221-228.

Kazazian, H.H., Jr., E.G.D. Tuddenham, and S.E. Antonarakis. 1995. Haemophilia A and parahaemophilia: Deficiencies of factors VIII and V. In The metabolic and molecular bases of inherited disease, 7 th edition (ed. C.R. Scriver, A.L. Beaudet, W.S. Sly, and D. Valle), pp. 3241-3267. McGraw-Hill, New York, NY.

Keller, S.A., J.M. Jones, A. Boyle, L.L. Barrow, P.D. Killen, D.G. Green, N.V. Kapousta, P.F. Hitchcock, R.T. Swank, and M.H. Meisler. 1994. Kidney and retinal defects (Krd), a transgene-induced mutation with a deletion of mouse chromosome 19 that includes the Pax2 locus. Genomics 23: 309320.

Kelly, E.J. and R.D. Palmiter. 1996. A murine model of Menkes disease reveals a physiological function of metallothionein. Nature Genet. 13: 219-222.

Klebig, M.L., L.B. Russell, and E.M. Rinchik. 1992. Murine fumarylacetoacetate hydrolase (Fah) gene is disrupted by a neonatally lethal albino deletion that defines the hepatocytespecific developmental regulation 1 (hsdr-1) locus. Proc. Natl. Acad. Sci. 89: 1363-1367.

Knecht, T.P. and C.K. Glass. 1995. The influence of molecular biology on our understanding of lipoprotein metabolism and the pathobiology of atherosclerosis. Adv. Genet. 32: 141199.

Knudson, A.G. 1988. Hereditary cancers disclose a class of cancer genes. Cancer 63: 1888-1891.
Kreidberg, J.A., H. Sariola, J.M. Loring, M. Maeda, J. Pelletier, D. Housman, and R. Jaenisch. 1993. WT-1 is required for early kidney development. Cell 74: 679-691.

LaFerla, F.M., B.T. Tinkle, C.J. Bieberich, C.C. Haudenschild, and G. Jay. 1995. The Alzheimer's A $\beta$ peptide induces neurodegeneration and apoptotic cell death in transgenic mice. Nature Genet. 9: 21-30.

LaSpada, A.R., E.M. Wilson, D.B. Lubahn, A.E. Harding, and K.H. Fischbeck. 1991. Androgen receptor gene mutations in $\mathrm{X}$-linked spinal and bulbar muscular atrophy. Nature 352: $77-79$.

Lavigueur, A., V. Maltby, D. Mock, J. Rossant, T. Pawson, and A. Bernstein. 1989. High incidence of lung, bone, and lymphoid tumors in transgenic mice overexpressing mutant alleles of the p53 oncogene. Mol. Cell. Biol. 9: 3982-3991.

Leach, F.S., N.C. Nicolaides, N. Papadopoulos, B. Liu, J. Jen, R. Parsons, P. Peltomäki, P. Sistonen, L.A. Aaltonen, M. Nyström-Lahti, X.-Y. Guan, J. Zhang, P.S. Meltzer, J.-W. Yu, F.-T. Kao, D.J. Chen, K.M. Cerosaletti, R.E.K. Fournier, S. Todd, T. Lewis, R.J. Leach, S.L. Naylor, J. Weissenbach, J.-P. Mecklin, H. Järvinen, G.M. Petersen, S.R. Hamilton, J. Green, J. Jass, P. Watson, H.T. Lynch, J.M. Trent, A. de la Chapelle, K.W. Kinzler, and B. Vogelstein. 1993. Mutations of a mutS homolog in hereditary nonpolyposis colorectal cancer. Cell 75: 1215-1225.

Lei, K.-J., H. Chen, C.-J. Pan, J.M. Ward, B. Mosinger, Jr., E.J. Lee, H. Westphal, B.C. Mansfield, and J.Y. Chou. 1996. Glucose6-phosphatase dependent substrate transport in the glycogen storage disease type-1a mouse. Nature Genet. 13: 203-209.

Leonard, W.J., M. Noguchi, S.M. Russell, and O.W. McBride. 1994. The molecular basis of X-linked severe combined immunodeficiency: The role of the interleukin-2 receptor $\gamma$ chain as a common $\gamma$ chain, $\gamma_{c}$. Immunol. Rev. 138: 61-86.

Levine, A.J., J. Momand, and C.A. Finlay. 1991. The p53 tumour suppressor gene. Nature 351: 453-456.

Levinson, B., C. Vulpe, B. Elder, C. Martin, F. Verley, S. Packman, and J. Gitschier. 1994. The mottled gene is the mouse homologue of the Menkes disease gene. Nature Genet. 6: 369-373

Li, S.-W., D.J. Prockop, H. Helminen, R. Fässler, T. Lapveteläinen, K. Kiraly, A. Peltarri, J. Arokoski, H. Lui, M. Arita, and J.S. Khillan. 1995a. Transgenic mice with targeted inactivation of the Col2a1 gene for collagen II develop a skeleton with membranous and periosteal bone but no endochondral bone. Genes \& Dev. 9: 2821-2830.

Li, T. and B.L. Davidson. 1995. Phenotype correction in retinal pigment epithelium in murine mucopolysaccharidosis VII by adenovirus-mediated gene transfer. Proc. Natl. Acad. Sci. 92: $7700-7704$.

Li, Y., D.A. Lacerda, M.L. Warman, D.R. Beier, H. Yoshioka, Y. Ninomiya, J.T. Oxford, N.P. Morris, K. Andrikopoulos, F. Ramirez, B.B. Wardell, G.D. Lifferth, C. Teuscher, S.R. Woodward, B.A. Taylor, R.E. Seegmiller, and B.R. Olsen. 1995b. A fibrillar collagen gene, Col11a1, is essential for skeletal morphogenesis. Cell 80: 423-430.

Lin, S.-C., C.R. Lin, I. Gukovsky, A.J. Lusis, P.E. Sawchenko, and M.G. Rosenfeld. 1993. Molecular basis of the little mouse phenotype and implications for cell type-specific growth. Nature 364: 208-213.

Lindberg, R.L.P., C. Porcher, B. Grandchamp, B. Ledermann, K. Bürki, S. Brandner, A. Aguzzi, and U.A. Meyer. 1996. Porphobilinogen deaminase deficiency in mice causes a neuropathy resembling that of human hepatic porphyria. Nature Genet. 12: 195-198.

Linton, M.F., J.B. Atkinson, and S. Fazio. 1995. Prevention of atherosclerosis in apolipoprotein E-deficient mice by bone 
marrow transplantation. Science 267: 1034-1037.

Liu, X., H. Wu, M. Byrne, J. Jeffrey, S. Krane, and R. Jaenisch. 1995a. A targeted mutation at the known collagenase cleavage site in mouse type I collagen impairs tissue remodeling. I. Cell. Biol. 130: 227-237.

Liu, Y.H., R. Kundu, L. Wu, W. Luo, M.A. Ignelzi, Jr., M.L. Snead, and R.E. Maxson, Jr. 1995b. Premature suture closure and ectopic cranial bone in mice expressing $M s x 2$ transgenes in the developing skull. Proc. Natl. Acad. Sci. 92: 61376141.

Lledo, P.-M., P. Tremblay, S.J. DeArmond, S.B. Prusiner, and R.A. Nicoll. 1996. Mice deficient for prion protein exhibit normal neuronal excitability and synaptic transmission in the hippocampus. Proc. Natl. Acad. Sci. 93: 2403-2407.

Lloyd, C., Q.C. Yu, J. Cheng, K. Turksen, L. Degenstein, E. Hutton, and E. Fuchs. 1995. The basal keratin network of stratified squamous epithelia: Defining K15 function in the absence of K14. J. Cell. Biol. 129: 1329-1344.

Longo, G., R. Strinati, F. Poli, and F. Fumi. 1987. Genetic factors in nonspecific bronchial hyperreactivity. An epidemiologic study. Am. J. Dis. Child. 141: 331-334.

Ma, J., J.C. Norton, A.C. Allen, J.B. Burns, K.W. Hasel, J.L. Burns, J.G. Sutcliffe, and G.H. Travis. 1995. Retinal degeneration slow $(r d s)$ in mouse results from simple insertion of a $t$ haplotype-specific element into protein-coding exon II. Genomics 28: 212-219.

McInnes, R.R. and R.A. Bascom. 1992. Retinal genetics: A nullifying effect for rhodopsin. Nature Genet. 1: 155-157.

McKusick, V.A., C.A. Francomano, S.E. Antonarakis, and P.L. Pearson. 1994. Mendelian inheritance in man. A catalog of human genes and genetic disorders, 11 th edition. Johns Hopkins University Press, Baltimore, MD.

McLaughlin, M.E., M.A. Sandberg, E.L. Berson, and T.P. Dryia. 1993. Recessive mutations in the gene encoding the $\beta$-subunit of rod phosphodiesterase in patients with retinitis pigmentosa. Nature Genet. 4: 130-133.

McLaughlin, M.E., T.L. Ehrhart, E.L. Berson, and T.P. Dryja. 1995. Mutation spectrum of the gene encoding the $\beta$-subunit of rod phosphodiesterase among patients with autosomal recessive retinitis pigmentosa. Proc. Natl. Acad. Sci. 92: 32493253.

MacLennan, D.H. and M.S. Phillips. 1992. Malignant hyperthermia. Science 256: 789-794.

MacPhee, M., K.P. Chepenik, R.A. Liddell, K.K. Nelson, L.D. Siracusa, and A.M. Buchberg. 1995. The secretory phospholipase A2 gene is a candidate for the Mom1 locus, a major modifier of $A p c^{M i n}$-induced intestinal neoplasia. Cell 81: 957-966.

Mahley, R.W. and S.C. Rall, Jr. 1995. Type III hyperlipoproteinemia (dysbetalipoproteinemia): The role of apolipoprotein $\mathrm{E}$ in normal and abnormal lipoprotein metabolism. In The metabolic and molecular bases of inherited disease, 7 th edition (ed. C.R. Scriver, A.L. Beaudet, W.S. Sly, and D. Valle), pp. 1953-1980. McGraw-Hill, New York, NY.

Malkin, D. 1994. Germline p53 mutations and heritable cancer. Annu. Rev. Genet. 28: 443-465.

Marchioli, R., R.M. Marfisi, F. Carinci, and G. Tognoni. 1996. Meta-analysis, clinical trials, and transferability of research results into practice: The case of cholesterol-lowering interventions in the secondary prevention of coronary heart disease Arch. Intern. Med. 156: 1158-1172.

Maréchal, V., N. Naffakh, O. Danos, and J.M. Heard. 1993. Disappearance of lysosomal storage in spleen and liver of mucopolysaccharidosis VII mice after transplantation of genetically modified bone marrow cells. Blood 82: 1358-1365.

Markert, M.L. 1994. Molecular basis of adenosine deaminase deficiency. Immunodeficiency 5: 141-157.

Martini, R., J. Zielasek, K.V. Toyka, K.P. Giese, and M. Schachner. 1995. Protein zero (PO)-deficient mice show myelin degeneration in peripheral nerves characteristic of inherited human neuropathies. Nature Genet. 11: 281-286.

Masliah, E., M. Mallory, N. Ge, M. Alford, I. Veinbergs, and A.D. Roses. 1995. Neurodegeneration in the central nervous system of apoE-deficient mice. Exp. Neurol. 136: 107-122.

Massague, J. 1996. Crossing receptor boundaries. Nature 382: 29-30.

Masters, B.A., E.J. Kelly, C.J. Quaife, R.L. Brinster, and R.D. Palmiter. 1994. Targeted disruption of metallothionein I and II genes increases sensitivity to cadmium. Proc. Natl. Acad. Sci. 91: 584-588.

Megeney, L.A., B. Kablar, K. Garrett, J.E. Anderson, and M.A. Rudnicki. 1996. MyoD is required for myogenic stem cell function in adult skeletal muscle. Genes \& Dev. 10: 11731183.

Melo, J.A., J. Shendure, K. Pociask, and L.M. Silver. 1996. Identification of sex-specific quantitative trait loci controlling alcohol preference in C57BL/6 mice. Nature Genet. 13: 147153.

Mercer, J.F.B., A. Grimes, L. Ambrosini, P. Lockhart, J.A. Paynter, H. Dierick, and T.W. Glover. 1994. Mutations in the murine homologue of the Menkes gene in dappled and blotchy mice. Nature Genet. 6: 374-378.

Migchielsen, A.A.J., M.L. Breuer, M.A. van Roon, H. te Riele, C. Zurcher, F. Ossendorp, S. Toutain, M.S. Hershfield, A. Berns, and D. Valerio. 1995. Adenosine-deaminase-deficient mice die perinatally and exhibit liver-cell degeneration, atelectasis and small intestinal cell death. Nature Genet. 10: 279287.

Mitchell, G.A., M. Lambert, and R.M. Tanguay. 1995. Hypertyrosinemia. In The metabolic and molecular bases of inherited disease, 7 th edition (ed. C.R. Scriver, A.L. Beaudet, W.S. Sly, and D. Valle), pp. 1077-1 106. McGraw-Hill, New York, NY.

Mombaerts, P., J. Iacomini, R.S. Johnson, K. Herrup, S. Tonegawa, and V.E. Papaioannou. 1992. RAG-1-deficient mice have no mature B and T lymphocytes. Cell 68: 869-877.

Monaco, A.P. and J. Chelly. 1995. Menkes and Wilson diseases. Adv. Genet. 33: 233-253.

Moore, K.J. 1995. Insight into the microphthalmia gene. Trends Genet. 11: 442-448.

Moran, P.M., L.S. Higgins, B. Cordell, and P.C. Moser. 1995. Age-related learning deficits in transgenic mice expressing the 751-amino acid isoform of human $\beta$-amyloid precursor protein. Proc. Natl. Acad. Sci. 92: 5341-5345.

Moser, A.R., C. Luongo, K.A. Gould, M.K. McNeley, A.R. Shoemaker, and W.F. Dove. 1995. $A p c^{\text {Min }}$ : A mouse model for intestinal and mammary tumorigenesis. Eur. I. Cancer 31A: 1061-1064.

Moullier, P., D. Bohl, J.-M. Heard, and O. Danos. 1993. Correction of lysosomal storage in the liver and spleen of MPS VII mice by implantation of genetically modified skin fibroblasts. Nature Genet. 4: 154-159.

Mueller, R.F. 1994. The Denys-Drash syndrome. J. Med. Genet. 31: 471-477.

Muenke, M. and U. Schell. 1995. Fibroblast-growth-factor receptor mutations in human skeletal disorders. Trends Genet. 11: 308-313.

Müller, U., N. Cristina, Z.-W. Li, D.P. Wolfer, H.-P. Lipp, T. Rülicke, S. Brandner, A. Aguzzi, and C. Weissmann. 1994. Behavioral and anatomical deficits in mice homozygous for a modified $\beta$-amyloid precursor protein gene. Cell 79: 755765. 
Mulligan, L.M., J.B.J. Kwok, C.S. Healey, M.J. Elsdon, C. Eng, E. Gardner, D.R. Love, S.E. Mole, J.K. Moore, L. Papi, M.A. Ponder, H. Telenius, A. Tunnacliffe, and B.A.J. Ponder. 1993. Germ-line mutations of the RET proto-oncogene of multiple endocrine neoplasia type 2A. Nature 363: 458- 460.

Muragaki, Y., E.C.M. Mariman, S.E.C. van Beersum, M. Perälä, J.B.A. van Mourik, M.L. Warman, B.R. Olsen, and B.C.J. Hamel. 1996a. A mutation in the gene encoding the $\alpha 2$ chain of the fibril-associated collagen IX, COL9A2, causes multiple epiphyseal dysplasia (EDM2). Nature Genet. 12: 103105.

Muragaki, Y., S. Mundlos, J. Upton, and B.R. Olsen. 1996b. Altered growth and branching patterns in synpolydactyly caused by mutations in HOXD13. Science 272: 548-551.

Naash, M.I., J.G. Hollyfield, M.R. Al-Ubaidi, and W. Baehr. 1993. Simulation of human autosomal dominant retinitis pigmentosa in transgenic mice expressing a mutated murine opsin gene. Proc. Nat1. Acad. Sci. 90: 5499-5503.

Naash, M.L, N.S. Peachey, Z.-Y. Li, C.C. Gryczan, Y. Goto, J. Blanks, A.H. Milam, and H. Ripps. 1996. Light-induced acceleration of photoreceptor degeneration in transgenic mice expressing mutant rhodopsin. Invest. Ophthalmol. \& Visual Sci. 37: 775-782.

Nagase, H., S. Bryson, H. Cordell, C.J. Kemp, F. Fee, and A. Balmain. 1995. Distinct genetic loci control development of benign and malignant skin tumours in mice. Nature Genet. 10: 424-429.

Nakata, K., K. Ono, J.-I. Miyazaki, B.R. Olsen, Y. Muragaki, E. Adachi, K.-I. Yamamura, and T. Kimura. 1993. Osteoarthritis associated with mild chondrodysplasia in transgenic mice expressing $\alpha 1$ (IX) collagen chains with a central deletion. Proc. Natl. Acad. Sci. 90: 2870-2874.

Nasir, J., S.B. Floresco, J.R. O'Kusky, V.M. Diewert, J.M. Richman, J. Zeisler, A. Borowski, J.D. Marth, A.G. Phillips, and M.R. Hayden. 1995. Targeted disruption of the Huntington's disease gene results in embryonic lethality and behavioral and morphological changes in heterozygotes. Cell 81: 811823.

Naski, M.C., Q. Wang, J. Xu, and D.M. Ornitz. 1996. Graded activation of fibroblast growth factor receptor 3 by mutations causing achondroplasia and thanatophoric dysplasia. Nature Genet. 13: 233-237.

Nawrotzki, R., D.J. Blake, and K.E. Davies. 1996. The genetic basis of neuromuscular disorders. Trends Genet. 12: 294298.

Neufeld, E.F. and J. Muenzer. 1995. The mucopolysaccharidoses. In The metabolic and molecular bases of inherited disease, 7th edition (ed. C.R. Scriver, A.L. Beaudet, W.S. Sly, and D. Valle), pp. 2465-2494, McGraw-Hill, New York, NY.

Nicolaides, N.C., N. Papadopoulos, B. Liu, Y.-F. Wei, K.C. Carter, S.M. Ruben, C.A. Rosen, W.A. Haseltine, R.D. Fleischmann, C.M. Fraser, M.D. Adams, J.C. Venter, M.G. Dunlop, S.R. Hamilton, G.M. Petersen, A. de la Chapelle, B. Vogelstein, and K.W. Kinzler. 1994. Mutations of two PMS homologues in hereditary nonpolyposis colon cancer. $\mathrm{Na}$ ture 371: 75-80.

Nigro, J.M., S.J. Baker, A.C. Preisinger, J.M. Jessup, R. Hostetter, K. Cleary, S.H. Bigner, N. Davidson, S. Baylin, P. Devilee, T. Glover, F.S. Collins, A. Weston, R. Modali, R, C.C. Harris, and B. Vogelstein. 1989. Mutations in the p53 gene occur in diverse human tumour types. Nature 342: 705-708.

Olsen, B.R. 1995. Mutations in collagen genes resulting in metaphyseal and epiphyseal dysplasias. Bone 17: $45 \mathrm{~S}-49 \mathrm{~S}$.

Oostra, B.A. and P.J. Willems. 1995. A fragile gene. BioEssays 17: 941-947.

Otterbach, B. and W. Stoffel. 1995. Acid sphingomyelinase-de- ficient mice mimic the neurovisceral form of human lysosomal storage disease (Niemann-Pick disease). Cell 81: 1053-1061.

Overturf, K., M. Al-Dhalimy, R. Tanguay, M. Brantly, C.-N. Ou, M. Finegold, and M. Grompe. 1996. Hepatocytes corrected by gene therapy are selected in vivo in a murine model of hereditary tyrosinaemia type I. Nature Genet. 12: 266-273.

Paigen, B., A.S. Plump, and E.M. Rubin. 1994. The mouse as a model for human cardiovascular disease and hyperlipidemia. Curr. Opin. Lipidol. 5: 258-264.

Pászty, C., N. Mohandas, M.E. Stevens, J.F. Loring, S.A. Liebhaber, C.M. Brion, and E.M. Rubin. 1995. Lethal $\alpha$-thalassaemia created by gene targeting in mice and its genetic rescue. Nature Genet. 11: 33-39.

Pavan, W.J., S. Mac, M. Cheng, and S.M. Tilghman. 1995. Quantitative trait loci that modify the severity of spotting in piebald mice. Genome Res. 5: 29-41.

Peifer, M. 1996. Regulating cell proliferation: As easy as APC. Science 272: 974-975.

Pericak-Vance, M.A. and J.L. Haines. 1995. Genetic susceptibility to Alzheimer disease. Trends Genet. 11: 504-508.

Perou, C.M. and J. Kaplan. 1993. Complementation analysis of Chediak-Higashi syndrome: The same gene may be responsible for the defect in all patients and species. Somatic Cell Mol. Genet. 19: 459-468.

Perou, C.M., K.J. Moore, D.L. Nagle, D.J. Misumi, E.A. Woolf, S.H. McGrail, L. Holmgren, T.H. Brody, B.J. Dussault, Jr., C.A. Monroe, G.M. Duyk, R.J. Pryor, L. Li, M.J. Justice, and J. Kaplan. 1996. Identification of the murine beige gene by YAC complementation and positional cloning. Nature Genet. 13: 303-308.

Peters, L.L., C.S. Birkenmeier, R.T. Bronson, R.A. White, S.E. Lux, E. Otto, V. Bennett, A. Higgins, and J.E. Barker. 1991. Purkinje cell degeneration associated with erythroid ankyrin deficiency in $n b / n b$ mice. J. Cell Biol. 114: 1233-1241.

Pittler, S.J. and W. Baehr. 1991. Identification of a nonsense mutation in the rod photoreceptor cGMP phosphodiesterase $\beta$-subunit gene of the $r d$ mouse. Proc. Natl. Acad. Sci. 88: 8322-8326.

Plump, A.S. and J.L. Breslow. 1995. Apolipoprotein E and the apolipoprotein E-deficient mouse. Annu. Rev. Nutr. 15: 495518.

Pollak, M.R., E.M. Brown, Y.-H.W. Chou, S.C. Hebert, S.J. Marx, B. Steinmann, T. Levi, C.E. Seidman, and J.G. Seidman. 1993. Mutations in the human $\mathrm{Ca}^{2+}$-sensing receptor gene cause familial hypocalciuric hypercalcemia and neonatal severe hyperparathyroidism. Cell 75: 1297-1303.

Pollock, J.D., D.A. Williams, M.A. Gifford, L.L. Li, X. Du, J. Fisherman, S.H. Orkin, C.M. Doerschuk, and M.C. Dinauer. 1995. Mouse model of X-linked chronic granulomatous disease, an inherited defect in phagocyte superoxide production. Nature Genet. 9: 202-209.

Popko, B., J.F. Goodrum, T.W. Bouldin, S.H. Zhang, and N. Maeda. 1993. Nerve regeneration occurs in the absence of apolipoprotein E in mice. I. Neurochem. 60: 1155-1158.

Porter, R.M., S. Leitgeb, D.W. Melton, O. Swensson, R.A. Eady, and T.M. Magin. 1996. Gene targeting at the mouse cytokeratin 10 locus: Severe skin fragility and changes of cytokeratin expression in the epidermis. T. Cell Biol. 132: 925936.

Prockop, D.J. and K.I. Kivirikko. 1995. Collagens: Molecular biology, diseases, and potentials for therapy. Annu. Rev. Biochem. 64: 403-434.

Prusiner, S.B. 1996. Prions prions prions. In Curr. Topics Microbiol. and Immunol. (ed. S.B. Prusiner), vol. 207. SpringerVerlag, Berlin. 
Ptacek, L.J., R. Tawil, R.C. Griggs, A.G. Engel, R.B. Layzer, H. Kwiecinski, P.G. McManis, L. Santiago, M. Moore, G. Fouad, P. Bradley, and M.F. Leppert. 1994. Dihydropyridine receptor mutations cause hypokalemic periodic paralysis. Cell 77: 863-868.

Puffenberger, E.G., K. Hosoda, S.S. Washington, K. Nakao, D. DeWit, M. Yanagisawa, and A. Chakravarti. 1994. A missense mutation of the endothelin-B receptor gene in multigenic Hirschsprung's disease. Cell 79: 1257-1266.

Quinn, J.C., J.D. West, and R.E. Hill. 1996. Multiple functions for Pax6 in mouse eye and nasal development. Genes \& Dev. 10: $435-446$.

Radovick, S., M. Nations, Y. Du, L.A. Berg, B.D. Weintraub, and F.E. Wondisford. 1992. A mutation in the POU-homeodomain of Pit-1 responsible for combined pituitary hormone deficiency. Science 257: 1115-1118.

Ramesh, N., R. Fuleihan, and R. Geha. 1994. Molecular pathology of X-linked immunoglobulin deficiency with normal or elevated IgM (HIGMX-1). Immunol. Rev. 138: 87-104.

Ramirez, F. 1996. Fibrillin mutations in Marfan syndrome and related phenotypes. Curr. Opin. Genet. Dev. 6: 309-315.

Rawlings, D.J. and O.N. Witte. 1994. Bruton's tyrosine kinase is a key regulator in B-cell development. Immunol. Rev. 138: 105-119.

Reaume, A.G., J.L. Elliott, E.K. Hoffman, N.W. Kowall, R.J. Ferrante, D.F. Siwek, H.M. Wilcox, D.G. Flood, M.F. Beal, R.H. Brown, Jr., R.W. Scott, and W.D. Snider. 1996. Motor neurons in $\mathrm{Cu} / \mathrm{Zn}$ superoxide dismutase-deficient mice develop normally but exhibit enhanced cell death after axonal injury. Nature Genet. 13: 43-47.

Reddy, S., D.B.J. Smith, M.M. Rich, J.M. Leferovich, P. Reilly, B.M. Davis, K. Tran, H. Rayburn, R. Bronson, D. Cros, R.J. Balice-Gordon, and D. Housman. 1996. Mice lacking the myotonic dystrophy protein kinase develop a late onset progressive myopathy. Nature Genet. 13: 325-335.

Reitmair, A.H., R. Schmits, A. Ewel, B. Bapat, M. Redston, A. Mitri, P. Waterhouse, H.-W. Mittrücker, A. Wakeham, B. Liu, A. Thomason, H. Griesser, S. Gallinger, W.G. Ballhausen, R. Fishel, and T.W. Mak. 1995. MSH2 deficient mice are viable and susceptible to lymphoid tumours. Nature Genet. 11: $64-70$.

Renshaw, B.R., W.C. Fanslow III, R.J. Armitage, K.A. Campbell D. Liggit, B. Wright, B.L. Davison, and C.H. Maliszewski. 1994. Humoral immune responses in CD40 ligand-deficient mice. J. Exp. Med. 180: 1889-1900.

Rieux-Laucat, F., F. Le Deist, C. Hivroz, I.A.G. Roberts, K.M. Debatin, A. Fischer, and J.P. de Villartay. 1995. Mutations in Fas associated with human lymphoproliferative syndrome and autoimmunity. Science 268: 1347-1349.

Roos, D. 1994. The genetic basis of chronic granulomatous disease. Immunol. Rev. 138: 121-157.

Rossiter, B.J.F. and C.T. Caskey. 1995. Hypoxanthine-guanine phosphoribosyltransferase deficiency: Lesch-Nyhan syndrome and gout. In The metabolic and molecular bases of inherited disease, 7 th edition (ed. C.R. Scriver, A.L. Beaudet, W.S. Sly, and D. Valle), pp. 1679-1706. McGraw-Hill, New York, NY.

Rozmahel, R., M. Wilschanski, A. Matin, S. Plyte, M. Oliver, W. Auerbach, A. Moore, J. Forstner, P. Durie, J. Nadeau, C. Bear, and L.-C. Tsui. 1996. Modulation of disease severity in cystic fibrosis transmembrane conductance regulator deficient mice by a secondary genetic factor. Nature Genet. 12: 280287.

Russell, L.B., W.L. Russell, R. A. Popp, C. Vaughan, and K.B. Jacobson. 1976. Radiation-induced mutations at mouse hemoglobin loci. Proc. Natl. Acad. Sci. 73: 2843-2846.
Ryan, S.G., M.S. Buckwalter, J.W. Lynch, C.A. Handford, L. Segura, R. Shiang, J.J. Wasmuth, S.A. Camper, P. Schofield, and P. O'Connell. 1994. A missense mutation in the gene encoding the $\alpha_{1}$ subunit of the inhibitory glycine receptor in the spasmodic mouse. Nature Genet. 7: 131-135.

Sakaguchi, S., S. Katamine, N. Nishida, R. Moriuchi, K. Shigematsu, T. Sugimoto, A. Nakatani, Y. Kataoka, T. Houtani, S. Shirabe, H. Okada, S. Hasegawa, T. Miyamoto, and T. Noda. 1996. Loss of cerebellar Purkinje cells in aged mice homozygous for a disrupted Prp gene. Nature 380: 528-531.

Sands, M.S. and E.H. Birkenmeier. 1993. A single-base-pair deletion in the $\beta$-glucuronidase gene accounts for the phenotype of murine mucopolysaccharidosis type VII. Proc. Natl. Acad. Sci. 90: 6567-6571.

Sands, M.S., C. Vogler, J.W. Kyle, J.H. Grubb, B. Levy, N. Galvin, W.S. Sly, and E.H. Birkenmeier. 1994. Enzyme replacement therapy for murine mucopolysaccharidosis Type VII. $J$. Clin. Invest. 93: 2324-2331.

Sango, K., S. Yamanaka, A. Hoffman, Y. Okuda, A. Grinberg, H. Westphal, M.P. McDonald, J.N. Crawley, K. Sandhoff, K. Suzuki, and R.L. Proia. 1995. Mouse models of Tay-Sachs and Sandhoff diseases differ in neurologic phenotype and ganglioside metabolism. Nature Genet. 11: 170-176.

Santoro, M., G. Chiappetta, A. Cerrato, D. Salvatore, L. Zhang, G. Manzo, A. Picone, G. Portella, G. Santelli, G. Vecchio, and A. Fusco. 1996. Development of thyroid papillary carcinomas secondary to tissue-specific expression of the RET/ PTC1 oncogene in transgenic mice. Oncogene 12: 18211826.

Sanyanusin, P., L.A. Schimmenti, L.A. McNoe, T.A. Ward, M.E.M. Pierpont, M.J. Sullivan, W.B. Dobyns, and M.R. Eccles. 1995. Mutation of the $P A X 2$ gene in a family with optic nerve colobomas, renal anomalies and vesicoureteral reflux. Nature Genet. 9: 358-364.

Savitsky, K., A. Bar-Shira, S. Gilad, G. Rotman, Y. Ziv, L. Vanagaite, D.A. Tagle, S. Smith, T. Uziel, S. Sfez, M. Ashkenazi, I. Pecker, M. Frydman, R. Harnik, S.R. Patanjali, A. Simmons, G.A. Clines, A. Sartiel, R.A. Gatti, L. Chessa, O. Sanal, M.F. Lavin, N.G.J. Jaspers, A.M.R. Taylor, C.F. Arlett, T. Miki, S.M. Weissman, M. Lovett, F.S. Collins, and Y. Shiloh. 1995. A single ataxia telangiectasia gene with a product similar to PI-3 kinase. Science 268: 1749-1753.

Schedl, A., A. Ross, M. Lee, D. Engelkamp, P. Rashbass, V. van Heyningen, and N.D. Hastie. 1996. Influence of PAX6 gene dosage on development: Overexpression causes severe eye abnormalities. Cell 86: 71-82.

Schneider, A., J.J. Davidson, A. Wullrich, and M.W. Kilimann. 1993. Phosphorylase kinase deficiency in I-strain mice is associated with a frameshift mutation in the alpha subunit muscle isoform. Nature Genet. 5: 381-385.

Schuchardt, A., V. D'Agati, L. Larsson-Blomberg, F. Costantini, and V. Pachnis. 1994. Defects in the kidney and enteric nervous system of mice lacking the tyrosine kinase receptor Ret. Nature 367: 380-383.

Scriver, C.R., S. Kaufman, R.C. Eisensmith, and S.L.C. Woo. 1995. The hyperphenylalaninemias. In The metabolic and molecular bases of inherited disease, 7 th edition (ed. C.R. Scriver, A.L. Beaudet, W.S. Sly, and D. Valle), pp. 1015-1075. McGraw-Hill, New York, NY.

Schwarz, K., G.H. Gauss, L. Ludwig, U. Pannicke, Z. Li, D. Linder, W. Friedrich, R.A. Seger, T.E. Hansen-Hagge, S. Desiderio, M.R. Lieber, and C.R. Bartram. 1996. RAG mutations in human B cell-negative SCID. Science 274: 97-99.

Serrano, M., H.W. Lee, L. Chin, C. Cordon-Cardo, D. Beach, and R.A. DePinho. 1996. Role of the INK4a locus in tumor suppression and cell mortality. Cell 85: 27-37. 
Shedlovsky, A., J.D. McDonald, D. Symula, and W.F. Dove. 1993. Mouse models of human phenylketonuria. Genetics 134: 1205-1210.

Shehee, W.R., P. Oliver, and O. Smithies. 1993. Lethal thalassemia after insertional disruption of the mouse major adult $\beta$-globin gene. Proc. Natl. Acad. Sci. 90: 3177-3181.

Shiang, R., S.G. Ryan, Y.-Z. Zhu, A.F. Hahn, P. O'Connell, and J.J. Wasmuth. 1993. Mutations in the $\alpha_{1}$ subunit of the inhibitory glycine receptor cause the dominant neurologic disorder, hyperekplexia. Nature Genet. 5: 351-357.

Shimada, M., S. Ishibashi, T. Inaba, H. Yagyu, K. Harada, J.I. Osuga, K. Ohashi, Y. Yazaki, and N. Yamada. 1996. Suppression of diet-induced atherosclerosis in low density lipoprotein receptor knockout mice overexpressing lipoprotein lipase. Proc. Nat1. Acad. Sci. 93: 7242-7246.

Shinkai, Y., G. Rathbun, K.-P. Lam, E.M. Oltz, V. Stewart, M. Mendelsohn, J. Charron, M. Datta, F. Young, A.M. Stall, and F.W. Alt. 1992. RAG-2-deficient mice lack mature lymphocytes owing to inability to initiate V(D)| rearrangement. Cell 68: 855-867.

Sicinski, P., Y. Geng, A.S. Ryder-Cook, E.A. Barnard, M.G. Darlison, and P.J. Barnard. 1989. The molecular basis of muscular dystrophy in the $\mathrm{mdx}$ mouse: A point mutation. Science 244: 1578-1580.

Simmonds, H.A., A.S. Sahota, and K.J. Van Acker. 1995. Adenine phosphoribosyltransferase deficiency and 2,8-dihydroxyadenine urolithiasis. In The metabolic and molecular bases of inherited disease, 7 th edition (ed. C.R. Scriver, A.L. Beaudet, W.S. Sly, and D. Valle), pp. 1707-1724. McGrawHill, New York, NY.

Singer, G.G., A.C. Carrera, A. Marshak-Rothstein, C. MartinezA., and A.K. Abbas. 1994. Apoptosis, Fas and systemic autoimmunity: The MRL-lpr/lpr model. Curr. Opin. Immunol. 6: 913-920.

Siracusa, L.D., R. McGrath, Q. Ma, J.J. Moskow, J. Manne, P.J. Christner, A.M. Buchberg, and S.A. Jimenez. 1996. A tandem duplication within the fibrillin 1 gene is associated with the mouse tight skin mutation. Genome Res. 6: 300-313.

Skow, L.C., B.A. Burkhart, F.M. Johnson, R.A. Popp, D.M. Popp, S.Z. Goldberg, W.F. Anderson, L.B. Barnett, and S.E. Lewis. 1983. A mouse model for $\beta$-thalassemia. Cell 34: 1043-1052.

Smith, J.D., E. Trogan, M. Ginsberg, C. Grigaux, J. Tian, and M. Miyata. 1995. Decreased atherosclerosis in mice deficient in both macrophage colony-stimulating factor (op) and apolipoprotein E. Proc. Natl. Acad. Sci. 92: 8264-8268.

Snyder, E.Y., R.M. Taylor, and J.H. Wolfe. 1995. Neural progenitor cell engraftment corrects lysosomal storage throughout the MPS VII mouse brain. Nature 374: 367-370.

Spritz, R.A. 1994a. Molecular basis of human piebaldism. I. Invest. Dermatol. 103: 137S-140S.

_- 1994b. Molecular genetics of oculocutaneous albinism. Hum. Mol. Genet. 3: 1469-1475.

Steel, K.P. 1995. Inherited hearing defects in mice. Annu. Rev. Genet. 29: 675-701.

Steel, K.P. and S.D.M. Brown. 1994. Genes and deafness. Trends Genet. 10: 428-435.

Steel, K.P. and R.J.H. Smith. 1992. Normal hearing in Splotch $|S p|+\mid$, the mouse homologue of Waardenburg syndrome type 1. Nature Genet. 2: 75-79.

Stein, S.A., E.L. Oates, C.R. Hall, R.M. Grumbles, L.M. Fernandez, N.A. Taylor, D. Puett, and S. Jin. 1994. Identification of a point mutation in the thyrotropin receptor of the hyt/hyt hypothyroid mouse. Mol. Endocrinol. 8: 129-138.

Steingrímsson, E., A. Nii, D.E. Fisher, A.R. Ferré-D'Amaré, L.B. Russell, S.K. Burley, J.M. Ward, N.G. Copeland, and N.A. Jenkins. 1996. The semidominant $M i^{b}$ mutation identifies a role for the HLH dimerization domain in DNA binding and provides a model for retinal degenerative disease in humans. EMBO J. 15: 6280-6289.

Strachan, T. and A.P. Read. 1994. PAX genes. Curr. Opin. Genet. Dev. 4: 427-438.

Strittmatter, W.J. and A.D. Roses. 1995. Apolipoprotein E and Alzheimer disease. Proc. Nat1. Acad. Sci. 92: 4725-4727.

$\mathrm{Su}$, L.-K., K.W. Kinzler, B. Vogelstein, A.C. Preisinger, A.R. Moser, C. Luongo, K.A. Gould, and W.F. Dove. 1992. Multiple intestinal neoplasia caused by a mutation in the murine homolog of the APC gene. Science 256: 668-670.

Sunada, Y., S.M. Bernier, C.A. Kozak, Y. Yamada, and K.P. Campbell. 1994. Deficiency of merosin in dystrophic $d y$ mice and genetic linkage of laminin $M$ chain to $d y$ locus. $J$. Biol. Chem. 269: 13729-13732.

Sung, C.-H., C. Makino, D. Baylor, and J. Nathans. 1994. A rhodopsin gene mutation responsible for autosomal dominant retinitis pigmentosa results in a protein that is defective in localization to the photoreceptor outer segment. $J$. Neurosci. 14: 5818-5833.

Suter, U. and G.J. Snipes. 1995. Biology and genetics of hereditary motor and sensory neuropathies. Annu. Rev. Neurosci. 18: $45-75$.

Suzuki, K., Y. Suzuki, and K. Suzuki. 1995. Galactosylceramide lipidosis: Globoid-cell leukodystrophy (Krabbe disease). In The metabolic and molecular bases of inherited disease, 7 th edition (ed. C.R. Scriver, A.L. Beaudet, W.S. Sly, and D. Valle), pp. 2671-2692. McGraw-Hill, New York, NY.

Takahashi, K., J. Folmer, and P.A. Coulombe. 1994a. Increased expression of keratin 16 causes anomalies in cytoarchitecture and keratinization in transgenic mouse skin. J. Cell. Biol. 127: 505-520.

Takahashi, T., M. Tanaka, C.I. Brannan, N.A. Jenkins, N.G. Copeland, T. Suda, and S. Nagata. 1994b. Generalized lymphoproliferative disease in mice, caused by a point mutation in the Fas ligand. Cell 76: 969-976.

Takeshima, H., M. Iino, H. Takekura, M. Nishi, J. Kuno, O. Minowa, H. Takano, and T. Noda. 1994. Excitation-contraction uncoupling and muscular degeneration in mice lacking functional skeletal muscle ryanodine-receptor gene. Nature 369: 556-559.

Tassabehji, M., V.E. Newton, K. Leverton, K. Turnbull, E. Seemanova, J. Kunze, K. Sperling, T. Strachan, and A.P. Read. 1994. PAX3 gene structure and mutations: Close analogies between Wardenburg syndrome type 1 and the Splotch mouse. Hum. Mol. Genet. 3: 1069-1074.

Tassabehji, M., V.E. Newton, X.-Z. Liu, A. Brady, D. Donnai, M. Krajewska-Walasek, V. Murday, A. Norman, E. Obersztyn, W. Reardon, J.C. Rice, R. Trembath, P. Wieacker, M. Whiteford, R. Winter, and A.P. Read. 1995. The mutational spectrum in Waardenburg syndrome. Hum. Mol. Genet. 4: 21312137.

Telling, G.C., M. Scott, J. Mastrianni, R. Gabizon, M. Torchia, F.E. Cohen, S.J. DeArmond, and S.B. Prusiner. 1995. Prion propagation in mice expressing human and chimeric $\operatorname{PrP}$ transgenes implicates the interaction of cellular Prp with another protein. Cell 83: 79-90.

Telling, G.C., T. Haga, M. Torchia, P. Tremblay, S.J. DeArmond, and S.B. Prusiner. 1996. Interactions between wildtype and mutant prion proteins modulate neurodegeneration in transgenic mice. Genes \& Dev. 10: 1736-1750.

Tisch, R. and H. McDevitt. 1996. Insulin-dependent diabetes mellitus. Cell 85: 291-297.

Tobler, I., S.E. Gaus, T. Deboer, P. Achermann, M. Fischer, T. Rülicke, M. Moser, B. Oesch, P.A. McBride, and J.C. Manson. 1996. Altered circadian activity rhythms and sleep in 
mice devoid of prion protein. Nature 380: 639-642.

Toriello, H.V., T.W. Glover, K. Takahara, P.H. Byers, D.E. Miller, J.V. Higgins, and D.S. Greenspan. 1996. A translocation interrupts the COL5A1 gene in a patient with EhlersDanlos syndrome and hypomelanosis of Ito. Nature Genet. 13: $361-365$.

Townley, R.G., A. Bewtra, A.F. Wilson, R.J. Hopp, R.C. Nair, and G.D. Watt. 1986. Segregation analysis of bronchial response to methacholine inhalation challenge in families with and without asthma. Allergy Clin. Immunol. 77: 101107.

Travis, G.H. and J.E. Hepler. 1993. A medley of retinal dystrophies. Nature Genet. 3: 191-192.

Travis, G.H., M.B. Brennan, P.E. Danielson, C.A. Kozak, and J.G. Sutcliffe. 1989. Identification of a photoreceptor-specific mRNA encoded by the gene responsible for retinal degeneration slow (rds). Nature 338: 70-73.

Trudel, M., N. Saadane, M.-C. Garel, J. Bardakdjian-Michau, Y. Blouquit, J.-L. Guerquin-Kern, P. Rouyer-Fessard, D. Vidaud, A. Pachnis, P.-H. Roméo, Y. Beuzard, and F. Costantini. 1991. Towards a transgenic mouse model of sickle cell disease: Hemoglobin SAD. EMBO J. 10: 3157-3165.

Trudel, M., M.E. De Paepe, N. Chrétien, N. Saadane, J. Jacmain, M. Sorette, T. Hoang, and Y. Beuzard. 1994. Sickle cell disease of transgenic SAD mice. Blood 84: 3189-3197.

Tsang, S.H., P. Gouras, C.K. Yamashita, H. Kjeldbye, J. Fisher, D.B. Farber, and S.P. Goff. 1996. Retinal degeneration in mice lacking the $\gamma$ subunit of the rod cGMP phosphodiesterase. Science 272: 1026-1029.

Tu, P.-H., P. Raju, K.A. Robinson, M.E. Gurney, J.Q. Trojanowski, and V.M.-Y. Lee. 1996. Transgenic mice carrying a human mutant superoxide dismutase transgene develop neuronal cytoskeletal pathology resembling human amyotrophic lateral sclerosis lesions. Proc. Natl. Acad. Sci. 93: 3155-3160.

Tybulewicz. V.L.J., M.L. Tremblay, M.E. LaMarca, R. Willemsen, B.K. Stubblefield, S. Winfield, B. Zablocka, E. Sidransky, B.M. Martin, S.P. Huang, K.A. Mintzer, H. Westphal, R.C. Mulligan, and E.I. Ginns. 1992. Animal model of Gaucher's disease from targeted disruption of the mouse glucocerebrosidase gene. Nature 357: 407-410.

Valle, D. and O. Simell. 1995. The hyperornithinemias. In The metabolic and molecular bases of inherited disease, 7 th edition (ed. C.R. Scriver, A.L. Beaudet, W.S. Sly, and D. Valle), pp. 1147-1185, McGraw-Hill, New York, NY.

van Doorninck, J.H., P.J. French, E. Verbeek, R.H.P.C. Peters, H. Morreau, J. Bijman, and B.J. Scholte. 1995. A mouse model for the cystic fibrosis $\triangle \mathrm{F} 508$ mutation. $E M B O$ /. 14: 44034411 .

van Heyningen, V. 1994. One gene-Four syndromes. Nature 367: 319-320.

Veres, G., R.A. Gibbs, S.E. Scherer, and C.T. Caskey. 1987. The molecular basis of the sparse fur mouse mutation. Science 237: 415-417.

Vikkula, M., M. Metsäranta, and L. Ala-Kokko. 1994. Type II collagen mutations in rare and common cartilage diseases. Ann. Med. 26: 107-114.

Vikkula, M., E.C.M. Mariman, V.C.H. Lui, N.I. Zhidkova, G.E. Tiller, M.B. Goldring, S.E.C. van Beersum, M.C. de Waal Malefijt, F.H.J. van den Hoogen, H.-H. Ropers, R. Mayne, K.S.E. Cheah, B.R. Olsen, M.L. Warman, and H.G. Brunner. 1995. Autosomal dominant and recessive osteochondrodysplasias associated with the COL11A2 locus. Cell 80: 431437.

Vincent, N., T. Ragot, H. Gilgenkrantz, D. Couton, P. Chafey, A. Grégoire, P. Briand, J.-C. Kaplan, A. Kahn, and M. Perri- caudet. 1993. Long-term correction of mouse dystrophic degeneration by adenovirus-mediated transfer of a minidystrophin gene. Nature Genet. 5: 130-134.

Vortkamp, A., M. Gessler, and K.-H. Grzeschik. 1991. GL13 zinc-finger gene interrupted by translocations in Greig syndrome families. Nature 352: 539-540.

Voss, J.W. and M.G. Rosenfeld. 1992. Anterior pituitary development: Short tales from dwarf mice. Cell 70: 527-530.

Vyse, T.J. and J.A. Todd. 1996. Genetic analysis of autoimmune disease. Cell 85: 311-318.

Wajnrajch, M.P., J.M. Gertner, M.D. Harbison, S.C. Chua, Jr., and R.L. Leibel. 1996. Nonsense mutation in the human growth hormone-releasing hormone receptor causes growth failure analogous to the little (7it) mouse. Nature Genet. 12: 88-90.

Wang, T., A.M. Lawler, G. Steel, I. Sipila, A.H. Milam, and D. Valle. 1995. Mice lacking ornithine- $\delta$-amino-transferase have paradoxical neonatal hypoornithinaemia and retinal degeneration. Nature Genet. 11: 185-190.

Watanabe-Fukunaga, R., C.I. Brannan, N.G. Copeland, N.A. Jenkins, and S. Nagata. 1992. Lymphoproliferation disorder in mice explained by defects in Fas antigen that mediates apoptosis. Nature 356: 314-317.

Waymire, K.G., J.D. Mahuren, J.M. Jaje, T.R. Guilarte, S.P. Coburn, and G.R. MacGregor. 1995. Mice lacking tissue nonspecific alkaline phosphatase die from seizures due to defective metabolism of vitamin B-6. Nature Genet. 11: 45-51.

Weatherall, D.J., J.B. Clegg, D.R. Higgs, and W.G. Wood. 1995. The hemoglobinopathies. In The metabolic and molecular bases of inherited disease, 7 th edition (ed. C.R. Scriver, A.L. Beaudet, W.S. Sly, and D. Valle), pp. 3417-3484. McGrawHill, New York, NY.

Wehner, M., P.R. Clemens, A.G. Engel, and M.W. Kilimann. 1994. Human muscle glycogenosis due to phosphorylase kinase deficiency associated with a nonsense mutation in the muscle isoform of the alpha subunit. Hum. Mol. Genet. 3: 1983-1987.

Weil, D., S. Blanchard, J. Kaplan, P. Guilford, F. Gibson, J. Walsh, P. Mburu, A. Varela, J. Levilliers, M.D. Weston, P.M. Kelley, W.J. Kimberling, M. Wagenaar, F. Levi-Acobas, D. Larget-Piet, A. Munnich, K.P. Steel, S.D.M. Brown, and C. Petit. 1995. Defective myosin VIIA gene responsible for Usher syndrome type 1B. Nature 374: 60-61.

Wells, D.J., K.E. Wells, E.A. Asante, G. Turner, Y. Sunada, K.P. Campbell, F.S. Walsh, and G. Dickson. 1995. Expression of human full-length and minidystrophin in transgenic $m d x$ mice: Implications for gene therapy of Duchenne muscular dystrophy. Hum. Mol. Genet, 4: 1245-1250.

White, R.A., C.S. Birkenmeier, S.E. Lux, and J.E. Barker. 1990. Ankyrin and the hemolytic anemia mutation, $\mathrm{nb}$, map to mouse chromosome 8: Presence of the nb allele is associated with a truncated ankyrin. Proc. Natl. Acad. Sci. 87: 31173121.

White, R.A., L.L. Peters, L.R. Adkison, C. Korsgren, C.M. Cohen, and S.E. Lux. 1992. The murine pallid mutation is a platelet storage pool disease associated with the protein 4.2 (pallidin) gene. Nature Genet. 2: 80-83.

Whitney, J.B., III and E.S. Russell. 1980. Linkage of genes for adult $\alpha$-globin and embryonic $\alpha$-like globin chains. Proc. Natl. Acad. Sci. 77: 1087-1090.

Wicker, L.S., J.A. Todd, and L.B. Peterson. 1995. Genetic control of autoimmune diabetes in the NOD mouse. Annu. Rev. Immunol. 13: 179-200.

Williamson, D.J., M.L. Hooper, and D.W. Melton. 1992. Mouse models of hypoxanthine phosphoribosyltransferase deficiency. I. Inherit. Metab. Dis. 15: 665-673. 
Wilson, J.M. 1996. Round two for liver gene therapy. Nature Genet. 12: 232-233.

Wilson, R.W., C.M. Ballantyne, C.W. Smith, C. Montgomery, A. Bradley, W.E. O'Brien, and A.L. Beaudet. 1993. Gene targeting yields a CD18-mutant mouse for study of inflammation. J. Immunol. 151: 1571-1578.

Wolfe, J.H., M.S. Sands, J.E. Barker, B. Gwynn, L.B. Rowe, C.A. Vogler, and E.H. Birkenmeier. 1992. Reversal of pathology in murine mucopolysaccharidosis type VII by somatic cell gene transfer. Nature 360: 749-753.

Wong, P.C., C.A. Pardo, D.R. Borchelt, M.K. Lee, N.G. Copeland, N.A. Jenkins, S.S. Sisodia, D.W. Cleveland, and D.L. Price. 1995. An adverse property of a familial ALS-linked SOD1 mutation causes motor neuron disease characterized by vacuolar degeneration of mitochondria. Neuron 14: 11051116.

Worton, D.G. and M.H. Brooke. 1995. The X-linked muscular dystrophies. In The metabolic and molecular bases of inherited disease, 7 th edition (ed. C.R. Scriver, A.L. Beaudet, W.S. Sly, and D. Valle), pp. 4195-4226. McGraw-Hill, New York, NY.

Wu, C.-L. and D.W. Melton. 1993. Production of a model for Lesch-Nyhan syndrome in hypoxanthine phosphoribosyltransferase-deficient mice. Nature Genet. 3: 235-240.

Wu, X., M. Wakamiya, S. Vaishnav, R. Geske, C. Montgomery, Jr., P. Jones, A. Bradley, and C.T. Caskey. 1994. Hyperuricemia and urate nephropathy in urate oxidase-deficient mice. Proc. Natl. Acad. Sci. 91: 742-746.

Xu, H., X.-R. Wu, U.M. Wewer, and E. Engvall. 1994. Murine muscular dystrophy caused by a mutation in the laminin $\alpha 2$ (Lama2) gene. Nature Genet. 8: 297-301.

Yamaguchi, T.P., K. Harpal, M. Henkemeyer, and J. Rossant. 1994. Fgfr-1 is required for embryonic growth and mesodermal patterning during mouse gastrulation. Genes \& Dev. 8: 3032-3044.

Yamanaka, S., M.D. Johnson, A. Grinberg, H. Westphal, J.N. Crawley, M. Taniike, K. Suzuki, and R.L. Proia. 1994. Targeted disruption of the Hexa gene results in mice with biochemical and pathologic features of Tay-Sachs diseases. Proc. Nat1. Acad. Sci. 91: 9975-9979.

Young, S.G., R.V. Farese, Jr., V.R. Pierotti, S. Taylor, D.S. Grass, and M.F. Linton. 1994. Transgenic mice expressing human apoB100 and apoB48. Curr. Opin. Lipidol. 5: 94-101.

Zeitlin, S., J.-P. Liu, D.L. Chapman, V.E. Papaioannou, and A. Efstratiadis. 1995. Increased apoptosis and early embryonic lethality in mice nullizygous for the Huntington's disease gene homologue. Nature Genet. 11: 155-163.

Zheng, H., M. Jiang, M.E. Trumbauer, D.J.S. Sirinathsinghii, R. Hopkins, D.W. Smith, R.P. Heavens, G.R. Dawson, S. Boyce, M.W. Conner, K.A. Stevens, H.H. Slunt, S.S. Sisodia, H.Y. Chen, and L.H.T. Van der Ploeg. 1995. $\beta$-Amyloid precursor protein-deficient mice show reactive gliosis and decreased locomotor activity. Cell 81: 525-531.

Zhou, L., C.R. Dey, S.E. Wert, M.D. DuVall, R.A. Frizzell, and J.A. Whitsett. 1994. Correction of lethal intestinal defect in a mouse model of cystic fibrosis by human CFTR. Science 266: 1705-1708.

Zhou, X.Y., H. Morreau, R. Rottier, D. Davis, E. Bonten, N. Gillemans, D. Wenger, F.G. Grosveld, P. Doherty, K. Suzuki, G.C. Grosveld, and A. d'Azzo. 1995. Mouse model for the lysosomal disorder galactosialidosis and correction of the phenotype with overexpressing erythroid precursor cells. Genes \& Dev. 9: 2623-2634.

Zlotogora, J., I. Lerer, S. Bar-David, Z. Ergaz, and D. Abeliovich. 1995. Homozygosity for Waardenburg syndrome. Am. I. Hum. Genet. 56: 1173-1178.
Zoghbi, H.Y. and H.T. Orr. 1995. Spinocerebellar ataxia type 1. Semin. Cell. Biol. 6: 29-35. 


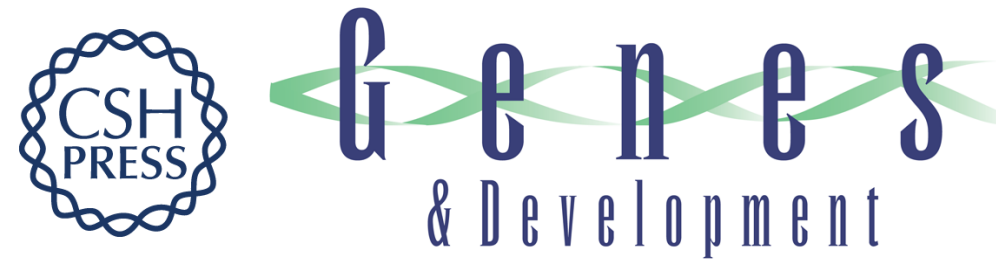

\section{Mouse models of human disease. Part II: recent progress and future directions.}

M A Bedell, D A Largaespada, N A Jenkins, et al.

Genes Dev. 1997, 11:

Access the most recent version at doi:10.1101/gad.11.1.11

Supplemental Material

References

License

Email Alerting Service
http://genesdev.cshlp.org/content/suppl/2000/05/07/11.1.11.DC1

This article cites 329 articles, 86 of which can be accessed free at:

http://genesdev.cshlp.org/content/11/1/11.full.html\#ref-list-1

Receive free email alerts when new articles cite this article - sign up in the box at the top right corner of the article or click here.

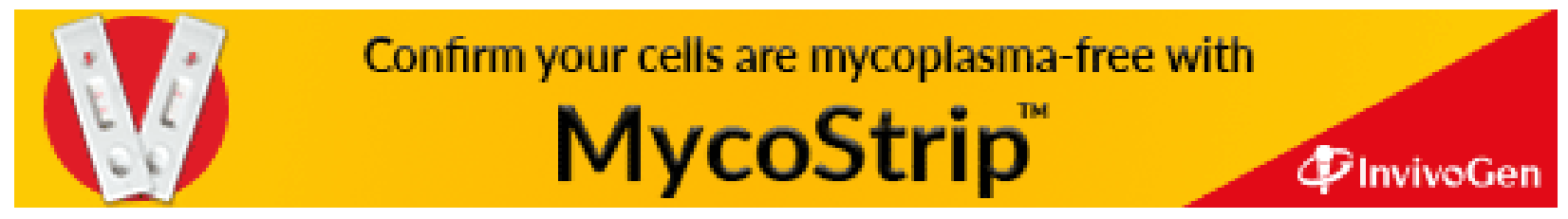

